er-in-Thanet from tolls ption which jor industry have had an s which did ead dependanchorages, Nercia had seace. ${ }^{204}$

Is on an earlier

\title{
The Frankish Annals of Lindisfarne and Kent
}

\author{
JOANNA STORY
}

The Frankish Annals of Lindisfarne and Kent lie at the root of the 'making of history' in Anglo-Saxon England. These annals are not well known, but they deserve direct attention since they provide factual details not just of 'what happened' in early Anglo-Saxon England, but also how such historical data was collected, copied, and transmitted across generations. Crucially, the annals contain chronological details that are not found in any other source, not even in Bede's Historia ecclesiastica gentis Anglormm ( $H E$ ), and they are a unique source for those details. But the marginality of these annals to Anglo-Saxon scholarship is less surprising when-we realize that the annals themselves were peripheral - quite literally marginal - to the manuscripts into which they were copied, first in England and later in Francia. They were written into the margins of Easter tables (hence the term, 'paschal annals') and - in truth - they are neither extensive nor particularly detailed; strictly speaking they are historical notes, inserted into the manuscripts long after the events they describe, rather than annals that record contemporary events. Nevertheless, they are a very rare piece of independent evidence not just for the history of the seventh century, but also for the type of 'raw material' that was available to Bede at Jarrow in the early decades of the eighth.

Scholars interested in the processes by which the history of early AngloSaxon England came to be recorded have long known of the existence of the annals that are referred to here as the 'Frankish Annals of Lindisfarne and Kent'. Georg Pertz first drew attention to them in 1826 when he edited some of the annals from a manuscript that had been copied probably at St Amand $c$. $800 .{ }^{1}$ Six other manuscripts containing entries that belonged to the same group of annals were subsequently recognized and edited in early volumes of the Mommmenta Germaniae Historica. As a consequence, these brief records of events

1 Würzburg, Universitätsbibliothek, M. p. th. f. 46 (St Amand, s. ix ${ }^{\text {in; }}$ provenance Salzburg). The annals are found on 2-21r, see further, below pp. 68-71. Pertz named the set of annals in this manuscript, within which the Anglo-Saxon entries are found, the Anmales Intarenses Maiores, ed. G. H. Pertz, MGH SS 1 (Hanover, 1826), 86-7. See also, Annales Intarenses maiores: Amales In'atenses maximi, maiores et minores, ed. H. Bresslau, MGH SS 30.ii (Hanover, 1934), 727-44. It is no. 242 in Jones's handlist of manuscripts, De Tempormm Ratione Liber, ed. C. W'. Jones, Bedae Opera de Temporibus (Cambridge, MA, 1943), pp. 242-56, repr. in his Beda Venerabilis Opera Didascalica, CCSL 123B (Turnhout, 1977) [hereafter, Jones, 'Handlist']. See also the handlist of eighth- and ninth-century manuscripts of the DTR in W. M. Stevens, Bede's Scientific Acbietement, Jarrow Lecture (1985), pp. 39-42, at 40 [hereafter, Stevens, 'Handlist']. 
in seventh-century Kent and Northumbria have been noted - fleetingly - by some of the most influential scholars of our subject, and the original information they contain has been absorbed into the standard reference works. ${ }^{2}$ However, the Frankish origins of all bar one of the manuscripts and the Frankish continuations to the English annals that they contain, have meant that this material has received much more detailed attention from scholars studying the development of historical writing in Carolingian Francia than it has from students of Anglo-Saxon England, for whom it remains comparatively unknown. ${ }^{3}$

\section{MANUSCRIPTS}

The Frankish Annals of Lindisfarne and Kent are preserved in the margins of seven copies of the Cyrlus paschalis of Dionysius Exiguus, all of which were made within a century of each other, the earliest $c .740$ and the latest $c .830$. The Anglo-Saxon material sits within a wider world history since all seven copies contain other entries recording various details of Roman, Byzantine or Frankish history. No single manuscript contains all the Anglo-Saxon entries: four contain just Northumbrian material, and the remainder conflate Northumbrian annals with entries concerning Kent. This arrangement, as well as connections between other texts in the manuscripts, suggests that the annals may have existed in two redactions that were transmitted independently to Francia, where they were copied into several Carolingian manuscripts. One

2 R. L. Poole, Cbronicles and Amals: a Brief Outline of their Origin and Grouth (Oxford, 1926), pp. 36 and 41; W. Levison, 'Bede as Historian', Bede: his Life, Times, and I'ritings. Essay's in Commemoration of the Tivelfth Centenary of his Death, ed. A. H. Thompson (Oxford, 1935), pp. 111-51, at 119; idem, England and the Continent in the Eighth Century (Oxford, 1946), pp. 270 and 273-5; Jones, Bedae Opera de Temporibus, p. 121; K. Harrison, The Framework of Anglo-Saxion Histor' to A.D. 900 (Cambridge, 1976), p. 45; D. Whitclock, After Bede, Jarrow Lecturc (1960), pp. 7-8; D. N. Dumville, 'The Local Rulers of Anglo-Saxon England to AD 927', Handbook of British Cbronology, 3rd ed., ed. E. B. Fryde, D. E. Greenway, S. Porter and I. Roy; R. Hist. Soc. Guides and Handbooks 2 (London, 1986), 1-25, at 12-13; S. Keynes, 'Appendix: Rulers of the English, c. 450-1066', The Blacknell Eng'lopaedia of Anglo-Saxon England, ed. M. Lapidge, J. Blair, S. Keynes and D. Scragg (Oxford, 1999), pp. 500-16, at 501-2.

A. Molinièr, Sonrres de l'bistoire de France des origines au 1494 (Paris, 1901), pp. 218-22; P. Lehmann, Fuldaer Studien, Sitzungsberichte der Bayerischen Akademie der Wissenschaften, phil.-hist. Kl. 3 (Munich, 1925); W. Levison, 'Die frühkarolingischen Annalen', Deutscblands Gescbicbtesquellen in Wittelalter. Vorzeit und Karolinger II. Die karolinger tom anfang des 8. Jabrhunderts bis zum tode Karls des Grossen, ed. W. Levison and H. Löwe (Weimar, 1953), pp. 180-92, at 189-92; F. L. Ganshof, 'L'historiographie dans la monarchie franque sous les Mérovingiens et les Carolingiens', SettSpol 17.2 (1971), 631-85, at 667-70; J. Prinz, Die Correger Analen: textbearbeitung and kommentar, $\Lambda$ bhandlungen zur Corveyer Geschichtsschriebung 7, Veröffentlichungen der historischen kommission für Westfalen 10 (Münster, 1982), 14-19 and 99-100; R. Corradini, "The Rhetoric of Crisis: Computus and Liber Amalis in Early Ninth-Century" Fulda', The Construction of Communities in the Early' Middle Ages: Text, Resourres and Artefacts, ed. R. Corradini, M. Diesenberger and H. Reimitz (Leiden, 2003), pp. 269-321 and pls. 1-5. 


\section{The Frankish Amnals of Lindisfarne and Kent}

setingly - by nal informaence works. ${ }^{2}$ ipts and the re meant that lars studying 1 it has from omparatively

te margins of - which were st $c .830$. The seven copies 3yzantine or axon entries: der conflate ment, as well at the annals pendently to 1scripts. One

(ford, 1926), pp. Fitings. Essaj's in iford, 1935), pp. 146), pp. 270 and e of Anglo-Saxion - Lecture (1960), , 927', Handbook I I. Roy; R. Hist. Ippendix: Rulers ', ed. M. Lapidge,

pp. 218-22; P. Wissenschaften, len', Deutscblands des 8. Jabibunderts 1, pp. $180-92$, at Mérovingiens et Annalen: textbearig 7, Veröffent-19 and $99-100$; y Ninth-Century and Artefacts, ed. and pls. 1-5. version, containing only Northumbrian material, is centred on manuscripts associated with Boniface's monastery at Fulda. ${ }^{4}$ The other, which brings together Northumbrian and Kentish annals, is more diffuse with copies surriving from St Amand/Salzburg, Auxerre and Verona. ${ }^{5}$ The differences between the text of the Kentish annals and the text of the Northumbrian entries, however, suggest that the material for each kingdom was compiled originally under different conditions, most likely in two different places; we may suppose that each set was compiled in the kingdom with which the text was concerned.

\section{Fulda and the Nortbumbrian annals}

The earliest of our seven manuscripts, $\mathbf{M}$, is one of those that contains Northumbrian annals but none of the Kentish material. It is made up of two parts, the earlier of which was written in Northumbria c. $740-50$ to judge by the script of the main hand, and is now Münster in Westfalen, Staatsarchiv MSC. I. 243, fols. 1-2 and 11-12 (Northumbria, s. viii ${ }^{2 / 4}$, provenance Fulda, Werden and Corvey). ${ }^{6}$ Folios 3-10, which complement the contents of the earlier Northumbrian leaves, were written in Fulda before the end of the eighth century (see below). The Northumbrian annals are found, as might be expected, in the section of the book that was written in northern England. ${ }^{7}$ This was once a handsome volume of generous proportions, with folios measuring about $300 \times 224 \mathrm{~mm}$ (estimated writing space $175 / 180 \times 140 / 175$ $\mathrm{mm}){ }^{8}$ It was ruled especially for the Easter tables, with only one table per

Manuscripts M, F, K, see below, pp. 61-7.

5 Manuscripts W, P1, P2, B, see below; pp. 67-72.

6 E.A. Lowe, Codices Lalini Antiquiores: a Palaeograpbical Guide to Latin Manuscripts prior to the Ninth Centurg [CL.A], 11 vols. plus Supplement (Oxford, 1934-71) IX.1233 [s. viii ${ }^{1}$ ] and Supplement, p. 4; idem, English Uncial (Oxford, 1960), Tab. XVIII a-c [s. viii']; Prinz, Corieger Annalen, pls. 14-16; B. Bischoff, V. Brown and J. J. John, 'Addenda to Codices Latini $\Lambda$ ntiquiores (II)', $M / S$ 54 (1992), 286-307, at 303; J. Petersohn, Neue Bedafragmente in northumbrischer unziale saec. VIII', Scriptorium 20 (1966), 215-47 [c. 740]; B. Bischoff, Mfittelalterlicbe Studien: Ausgen'äblte Aufsätze zur Sebriftkunde und Literaturegescbicbte, 3 vols. (Stuttgart, 1966-81) II, 337; Jones, 'Handlist', no. 37 [c. 746]; Stevens, 'Handlist', 39 [746-50]; H. Gneuss, Handlist of Anglo-Saxion Manuscripts: a List of Manuscripts and Manuscript Fragments I'ritten or On'ned in England up 10 1100, Med. and Renaissance Texts and Stud. 241 (Tempe, $\Lambda Z, 2001$ ), no. 856 [s. viii'].

7 These annals and those that follow them were edited by G. H. Pertz, MGH SS 3 (Hanover, 1839), 1-18; P. Jaffé, Monmmenta Corbeiensia, Bibliotheca rerum Germanicarum 1 (Berlin, 1864), 28-65; Prinz, Coneger Annalen, pp. 14-15. See also Lchmann, Fuldaer Studien, Pp. 37-8 and Molinièr, Sources de l'bistoire, p. 221, no. 723.

${ }^{8}$ Lowe estimates the original size of each folio to have been c. $300 \times 224 \mathrm{~mm}$, and the writing space $c$. 175-180 $\times 140-175 \mathrm{~mm}$. The lower and right margins are usually trimmed in the published plates disguising the scale of the manuscript. The lower margin is more than $11 \mathrm{~cm}$ in height in the extant fragments, with up to $6 \mathrm{~cm}$ in the right-hand margin where the $A$ ngloSaxon annals are written; Lowe, CLA IX.1233, and Petersohn, 'Ncue Bedafragmente', 218; Prinz, Corveyer Annalen, pls. 14-16. 


\section{Joanna Story}

page and ample space for marginal notes at the foot and in the right-hand margin. Indeed, it is possible that the page was designed with an extra column for the annals, making them integral to the text being presented, rather than as a marginal afterthought. All that now remains of this section of the book are four fragments of the folios that contained the Easter tables - for the years 589-740, which survive as bookbinding off-cuts (now fols. 1, 2, 11 and 12). Some have Anglo-Saxon annals added in the right-hand margin as well as a more extensive series added to the book at Corvey in the twelfth century. ${ }^{9}$ The scribe of the tables was also responsible for copying the annals, and used a compressed uncial script of 'unmistakable Northumbrian type' for the text of both. ${ }^{10}$ The four bookbinding strips are arranged today not in the original order of the tables, but according to the chronology of the later annals, known as the Amales Corbienses, that are written into the lower margins (pl. Ia). ${ }^{11}$

The fragmentary state of these leaves makes it hard to ascertain the structure of the gathering to which they once belonged. But it is likely that additional leaves, now lost, extended the tables beyond 740 , into 'present and future time' for the scribe who was copying them. Our four fragments were probably part of a quaternion, the last leaf of which contained tables 12 and 13 for the years $741-78$, perhaps part of a full 532-year Cjclus pasclialis covering the years 532-1063. ${ }^{12}$ This arrangement is supported by the chance survival of several similar fragments now in Bückeburg and Braunschweig from a contemporary copy of Bede's De temportum ratione (DTR), also copied in Northumbrian uncials, written very likely by the same scribe and deriving from the same volume as our Easter tables and their accompanying annals. ${ }^{13}$ The $D T R$ is usually prefaced by

9 The Annales Corbienses span the years 822-1117; G. H. Pertz, MGH SS 1 (Hanover, 1826), 1-18; Prinz, Corveyer Amalen, pp. 101-39 and pls. 14-16.

${ }^{10}$ Lowe, CIA IX.1233; idem, English Uncial, pp. 13 and 20, and pl. XVIII (a-c), 'the script is Amiatine capitular type in decline'. See also, M. B. Parkes, The Scriplorium of IF'earmontl-Jarron', Jarrow Lecture (1982), repr. in his Scribes, Scripts and Readers: Studies in the Commnnication, Presentation and Dissemination of Medietal Texts (London, 1991), pp. 93-119, at 95-6.

11 The original order was fols. 11, 12, 1, 2; Lowe, CLA, IX.1233; Petersohn, 'Ncue Bedafragmente', pp. 239 (at n. 158) and 241.

12 Corradini, 'Rhetoric of Crisis', pp. 281-2. If correct the tables must have been prefaced by three folios containing prefatory material.

13 Bückeburg, Niedersächsisches Staatsarchiv; Depot 3/1, fols. i-viii and Braunschweig, Stadtbibliothek, Fragm. 70; Gneuss, Handlist, no. 856; Parkes, 'Scriptorium', p. 96. Fragments of another very early copy of the DTR, perhaps from Bede's lifetime, also in Northumbrian uncial survive as Darmstadt, Hessische Landes- und Hochschulbibliothek, 4262, s. viii ${ }^{2 / 4}$ (Wearmouth-Jarrow); Gneuss, Handist, no. 818; F. Wallis, Bede: the Reckoning of Time, Translated 'Texts for Historians 29 (Liverpool, 1999), lxxxvi; K. H. Staub, 'Ein Beda-Fragment des 8. Jahrhunderts in der Hessischen Landes und Hochschulbibliothek Darmstadt', Bibliothek und W'issenschaft 17 (1983), 1-7. 


\section{The Frankish Amnals of Lindisfarne and Kent}

e right-hand ith an extra $g$ presented, this section Easter tables ow fols. 1, 2, and margin 1 the twelfth $\mathrm{g}$ the annals, mbrian type' today not in r of the later o the lower

in the strucsly that addint and future 'ere probably ad 13 for the ing the years ral of several ontemporary brian uncials, olume as our $y$ prefaced by

Hanover, 1826),

c), 'the script is "earmonth-Jarron', e Communication, $95-6$.

:tcrsohn, 'Neue

een prefaced by

Braunschweig, ?. 96. Fragments is Northumbrian 4262 , s. $\mathrm{viii}^{2 / 4}$ ckoning of Time, i Beda-Fragment istadt', Bibliotbek a copy of the full Cyclus pasclualis, ${ }^{14}$ and this copy of the DTR was written by a hand using a compact English uncial script which is sufficiently similar to that of the Easter tables and annals to be fairly considered the work of the same scribe. $^{15}$

Petersohn argued that the uncial script used in these fragments also bears a close resemblance to that used in parts of the St Petersburg HE, which contains chronological notes on $159 \mathrm{r}$ implying that they were composed in $746 .{ }^{16}$ This comparison led Petersohn to argue that the Münster-Bückeburg codex had been written at Wearmouth-Jarrow $c .740$, a view supported by Parkes's analy'sis of the book-hands used at Bede's monastery in the earlier part of the eighth century. But, not wishing to contradict Lowe's statement that the Easter tables had been copied 'possibly at Lindisfarne to judge by contents', Petersohn suggested that the manuscript had been taken to Lindisfarne at some point in the second half of the eighth century where the annals had been added. ${ }^{17}$ This second stage is unnecessary; Petersohn's interpretation of the more 'decadent' script of the annals as a chronological indicator reflects simply' the relative marginality of the annals and the slightly less carcful script used to write them. There is no palacographic reason to suppose that the annals were written in a different place or at a different time from the tables. Furthermore, as we shall see, all of the Northumbrian information contained in the annals could have been derived from Bede's $H E$ and need not have come direct from Lindisfarne. It is most likely, therefore, that our earliest copy of the annals was

${ }^{14}$ As stated by Bede in DTR, ch. 65. The presence of the names and dates of both Roman and Byzantine emperors in the margins of the uncial portion of the text also supports the case for a full Great Cycle. Had the scribe copied only the tables to 778, the chronology of the emperors in the 'first' Great Cycle would have been broken in $A D 246(778$ minus $532=246)$ only to be resumed in 532 at the start of the 'second' Great Cycle; 'Adnotationes antiquiores ad cyclos Dionysianos', ed. 'T. Mommsen, MGH, Auct. antiq. 9 (Berlin, 1891), 751-6, and below pp. 76-9.

15 The low, almost horizontal bar of $N$ is particularly characteristic. Petersohn, 'Ncue Bedafragmentc', 239-47; idem, 'Die Bückeburger Fragmente von Bedas De tempormm ratione', DALEII 22 (1966), 587-97; Wallis, Reckoning of Timse, p. Ixxxvi; Gneuss, Handlist, no. 856 and Pp. 120-1.

${ }^{16}$ St Petersburg, National Library of Russia, lat. Q. v. I. 18 (Wearmouth-Jarrow, $731 \times 746$ ); Gncuss, Handlist, no. 846; Petersohn, 'Neue Bedafragmente', pp. 233-9 and pl. 18. See also, O. Arngart, The Leningrad Bede: an Eighth Century Mlanuscript of the Vesterable Bede's Historia Ecclesiastica Gentis Anglorum in the Public Library, Leningrad, EEMII 2 (Copenhagen 1952), 17-18; D. H. Wright, 'The Date of the Leningrad Bede', $R B 71$ (1961), 266-73.

${ }_{17}$ Petersohn, 'Neue Bedafragmente', pp. 237 and 247. Lowe's comments are made in CLA IX.1233, but he did not repeat the Lindisfarne attribution for the tables or annals in English Uncial, p. 20; $\Lambda$. Borst, Die Karolingische Kalenderreform, MGH Schriften 46 (Hanover, 1998), 50. See also, Corradini, 'Rhetoric of Crisis', pp. 282-3, where he suggests that the whole of the uncial element in $\mathbf{M}$ could have been copied in Fulda from an Insular exemplar; but this introduces another stage into the transmission process for which there is no real evidence.

63 


\section{Joanna Story'}

copied at Wearmouth-Jarrow at some point after the completion of the $H E$ in 731 and before $c .750$.

There are good grounds, in any case, for thinking that the manuscript left Northumbria fairly soon after it had been written and that it arrived in Fulda around 750 , or by 778 'at the latest'. ${ }^{18}$ The uncial Easter tables were amplified at Fulda by a second gathering containing tables 14-28 (779-1063), which replaced or completed the second half of the Great Cycle in the uncial copy: This second gathering was copied by a Fuldan scribe using a distinctive, skilled Insular minuscule some time before the end of the eighth century, probably not long before 779 when the new tables commenced; these leaves are now Münster in Westfalen, Staatsarchiv, MSC. I. 243, fols. 3-10 (Fulda, s. viii ${ }^{3 / 4}$; provenance Werden and Corvey). ${ }^{19}$ This gathering survives intact as four conjoined bifolia, cut and ruled to match the uncial portion of the manuscript with a single table to a page; the verso of the last folio contains computistical notes in a later, ninth-century hand. That the uncial and minuscule sections of $M$ have been together from an early stage, is shown by the addition of annals which indicate that, by the second decade of the ninth century at the latest, the manuscript had left Fulda for the monasteries of Werden and Corvey; indeed, it may have left as early as 780 since none of the characteristic annals concerning Fulda was added to either section. ${ }^{20}$ This must imply that the original structure of the uncial codex containing the Easter tables and Bede's DTR was rearranged to incorporate the new minuscule quaternion very early in its history.

The restructuring of the Northumbrian uncial volume may have been associated with the compilation of another computistical manuscript at Fulda. 'The

18 Corradini, 'Rhetoric of Crisis', p. 281; R. Corradini, 'Zeiträume - Schrifträume. Überlegungen zur Komputistik und Marginalchronographie am Beispeil der Annales Fuldenses antiquissimi, Iom Nutzen des Scbreibens: Sociales Gedäcbtnis, Herrschaft und Besitz in Mittelalter, ed. W. Pohl

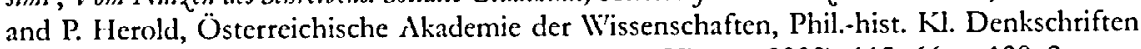
306, Forschungen zur Geschischte des Mittelalters 5 (Vienna, 2002), 113-66, at 130-2.

${ }^{19}$ Lowe, CLA IX.1234; B. Bischoff, Katalog der festländiscben Handscbriften des nesmten Jabrbunderts (nit Alusmabme der nisigotiscben), 2 vols. (Wiesbaden, 1998-2004) II, no. 3546a, 303; Prinz, Die Cortejer Amalen, pp. 10-13 and pls. 1-13. On the Anglo-Saxon script of Fulda, see esp. H. Spilling, 'Angelsächsische Schrift in Fulda', Ion der Klosterbibliotbek zur Landesbibliotbek. Beiträge zum ₹meihmudertjäbrigen Besteben der Hessiscben Landesbibliotbek Fulda, ed. A. Brall, Bibliothek des Buchwesens 6 (Stuttgart and Fulda, 1978), 47-98. Corradini argues that this second quire was completed in two stages, to 822 and then to 1063 . There is a cross in the left-hand margin against 822 with an annal reading incboatis noure corbeie monasterii (4r) but no other indication of a change in stint; Corradini, 'Rhetoric of Crisis', 283-4; Prinz, Die Correjer Annalen, pls. 1b and $16 \mathrm{~b}$.

20 Though the crucial folio with the tables for 741-78 which would have carried these entries is now lost. Prinz, Correjer Anmalen, pp. 100-39; Corradini, 'Rhetoric of Crisis', pp. 284-5. The alternative scenario is that the tables in $\mathbf{M}$ were superceded at Fulda by $\mathbf{F}$, which acquired the additional Fulda annals. Corradini notes that the Werden annals, which begin in 809 , could have been added to the manuscript at Fulda. 


\section{The Frankish Annals of Lindisfarme and Kent}

Fuldan scribe who added the second gathering to $\mathbf{M}$ containing the Easter tables for 778-1063 was also responsible for copying the first part of the Gyclus pascbalis (as far as table 15 covering the years 798-816) for another manuscript, F. ${ }^{21}$ These Easter tables, now Munich, Bay'erische Staatsbibliothek, clm 14641, $32 \mathrm{v}-46 \mathrm{r}$ (Fulda, s. viiie ${ }^{\mathrm{x}}$; provenance Regensburg), were copied in Fulda in the closing decades of the eighth century, perhaps 6.780 , and are the only tables in our set not linked to a copy of the DTR. ${ }^{22}$ The uncial Easter tables and their accompanying Northumbrian annals in $\mathbf{M}$ served as the direct exemplar for $\mathbf{F}$ at least to the end of the eleventh paschal cycle (721-40). The scribe of $\mathbf{F}$ copied the Northumbrian annals from $\mathbf{M}$ very carefully, noting corrections to the chronology in exactly the same manner as he found in his exemplar. Thus, in the space alongside the calculations for the years 663 and 664, the uncial scribe of $\mathrm{M}$ had written a note about the 664 solar eclipse in the line above the entry for the departure of Colman from Northumbria. A scribe added a dotted line from the word eclipsis to the line below, indicating that it was to be read as a record for 664 and not 663 . The scribe of $F$ followed this layout exactly ( $p l$. I). Again, against the year 668 the uncial scribe of $\mathbf{M}$ drew a dotted line to indicate that the start of the reign of the Byzantine emperor Constantine IV should properly be read as an entry for 669 rather than 668 against which it was written, and the scribe of $F$ copied this exactly. Twice the scribe of $F$ corrected the reading from his exemplar; he changed the verb in the annal for 658 from Finan meritur (M) to Finan moritur $(F)$, and again in the annal for 664, from Colman abiit $(\mathbf{M})$ to Colman obiit $(\mathbf{F})$. His corrections were a reasonable inference given that the other annals refer either to the obits of bishops or accessions of kings, but his corrected reading changed Colman's departure in 664 to a record of his death, which was wrong (pl. I). ${ }^{23}$

${ }_{21}$ B. Bischoff, Die Sïdostdeutschen Scbreibschulen und Bibliotheken in der Karolingerzeit, 2 vols. (Wiesbaden, 1974-80), I, 252.

22 Bischoff, Katalog, II, no. 3235a, p. 261; Lowe, CLA IX.1306; C. Halm, F. Keinz, G. Meyer and G. Thomas, Catalogus Codicum Latinorum Bibliothecae Regiae Monacensis 2.ii (Nunich, 1876), 208-9. Spilling, 'Angelsächsische Schrift', 86; Corradini, 'Rhetoric of Crisis', pp. 287 and 294 at n. 107 (for the contents of the manuscript), and pls. 1-5; idem, 'Zeiträume - Schrifträume', pp. 134-6 and 164-5 (for a full codicological description). The manuscript also contains one of the carliest examples of Carolingian minuscule from Fulda, fols. 1-31 as well as an carly copy of Charlemagne's epitaph on 31v; B. Bischoff, 'Manuscripts in the Age of Charlemagne',

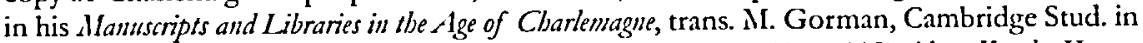
Palaeography and Codicology 1 (Cambridge, 1994), 20-55 (at 43, n. 113); idem, Katalog II, no. 3235, p. 261. Folios 46-7 contain early-ninth-century copies of two letters of Pliny; B. Munk Olsen, L'ÉEtude des auteurs classigues latin an XIe et XIIe siècles, 3 rols. (Paris, 1982-9) II, 278-9.

23 Lehmann, Fuldaer Studien, pp. 42-3. The correct reading is found alongside the Easter tables in both manuscripts now in Paris, P1 and P2. This reading implies that the scribes of those books either had access to $\mathbf{M}$ or, more probably; to another set of the Northumbrian annals, conflated with those of Kent. 
By comparing the range of annals in $\mathbf{F}$ with that in $\mathbf{M}$ we can suggest that $\mathbf{M}$ had originally contained a few more Northumbrian annals, and perhaps several additional records of the accession of Roman and Byzantine emperors, than survive in the mutilated uncial section of that book. $F$ has two Northumbrian annals that are absent from $\mathbf{M}$ in its present state; these note the death of Aidan in 651, Aidan episcopus obiit (35v), and the beginning of the reign of Gsred in 704, Osrediss regnarit (37v). It is possible that the Northumbrian annals finished in $\mathbf{M}$ as in $\mathbf{F}$, with the entry for the accession of Osred in $704 .^{24}$ F also contains a note of the death of Bede s.a. 735 , which marks the end of the Anglo-Saxon annals in that book. This entry is not in $\mathbf{M}$ since most of table $11(722-40)$ is missing; only the lowest line of the table, for the year 740 , survives on $2 \mathrm{v}$. 'The record of Bede's death may indeed have been in $\mathbf{M}$ but news of his death also reached Fulda by different means and could have been added to $\mathbf{F}$ independently of the annals in $\mathbf{M}$. This Fuldan scribe continued the annals that he had copied into $F$ with additional entries concerning Frankish events and the history of his own monastery; the last entry in his hand is that which records the conversion of the Saxons in 776. Eight other scribes amplified his notes by inserting further annals into the margins of $F$; these annals continue up to 822 and are commonly known as the Amales Fuldenses antiquissimi. ${ }^{25}$

Another copy of the Easter tables and their Northumbrian annals was made in Fulda between 814 and 822 under the supervision of Hrabanus Maurus. This manuscript, $\mathbf{K}$, is now Kassel, Hessische Landesbibliothek und Murhardsche Bibliothek (Gesamthochschulbibliothek), $2^{\circ} \mathrm{ms}$. astron. 2 (Fulda, c. 814-22), and has the full Cyclus pascbalis on $1 \mathrm{v}-8 \mathrm{r}$, copied in Carolingian minuscule by three hands. ${ }^{26}$ Folios $1 \mathrm{r}$ and $8 \mathrm{v}$ were originally blank, indicating

${ }^{24}$ See below; p. 78. See also, Lehmann, Fuldaer Studien, p. 42, and Corradini, 'Rhetoric of Crisis', p. 283 where it is argued that the obit of Bede marks the transition between the Northumbrian and Fuldan annals. Note too that Bede finished the De temporibus in 703.

${ }^{25}$ Annales Fuldenses antiguissimi, cd. G. H. Pertz, MGH SS 1 (Hanower, 1826), 95; ed. J. Grimm, MGH SS 2 (Hanover, 1829), 237; ed. Pertz, MGH SS 3 (Hanover, 1839), 116*-17; ed. F: Kurze, MGH SRG 7 (Hanover, 1891), 136-8; Molinièr, Sostres de lbistoire, p. 219, no. 710. Another late-eighth-or early-ninth-century manuscript from Fulda also contains the $A F A$ but without the Northumbrian entries, namely, Vienna, Osterrcichischen Nationalbibliothek, Crp 460 (pars II), on which, see E. Irblich, Karl der Grosse und die IV'issenscbaft. Ausstellung karolingischer bandscbriften der Österreicbischen Nationalbibliotbek zum Europa-Jabr 1993 (Vienna, 1994), no. 1, pp. 36-7. On the Annales Fuldenses antiquissimi and the relationship betwcen these manuscripts, see Lehmann, Fuldaer Studien, pp. 24-46; Corradini, 'Rhetoric of Crisis', pp. 286-92; idem, 'Zeiträume - Schrifträume', pp. 133-4 and 164-5.

26 Bischoff, Katalog I, no. 1790, p. 372; M. L. W. Laistner and H. H. King, A Hand-list of Bede Manuscripts (New York, 1943), p. 14; Jones, 'Handlist', no. 79; Lehmann, Fuldaer Studien, p. 33; H. Spilling, 'Dic frühe Phase karolingischer Minuskel in Fulda', Kloster Fulda in der IV't der Karolinger und Ottonen, ed. G. Schrimpf, Fuldaer Studien. Schriftenreihe der thcologischen 


\section{The Frankish Amnals of Lindisfarne and Kent}

uggest that nd perhaps z emperors, $E$ has two se note the of the reign rthumbrian ed in 704.24 the end of ost of table ar 740 , sur$\mathbf{A}$ but news seen added tinued the g Frankish and is that zer scribes of $F$; these 'es Fuldenses

; was made as Maurus. thek und 1. 2 (Fulda, Jarolingian indicating

ric of Crisis', between the in 703.

d. J. Grimm, 6*-17; ed. F! 219, no. 710 . the $A F A$ but liothek, Crp ing karolingis1a, 1994), no. these manupp. 286-92;

dd-list of Bede Studien, p. 33; 1 der llielt der neologischen that it was copied as a separate fascicle and was subsequently bound into the manuscript as a preface to Bede's DTR which follows on $10 \mathrm{v}-84 \mathrm{r}^{27}$ The manuscript, described as a pedagogical manual and probably intended as a school text, is dated both by its script, which belongs to the third phase of AngloSaxon script at Fulda $\left(\mathrm{s} . \mathrm{ix}^{1 / 3}\right)$, and by reference in the annals to the death of Charlemagne in 814 in the hand of the main scribe of the tables; it is likely that the book was completed before Hrabanus became abbot of Fulda in 822 . The Gyclus pascbalis in $\mathbf{K}$ incorporates the Northumbrian annals, and their Fulda Eontinuation, the Amnales Fuldenses antiquissimi. However, whereas the earlier scribe of $\mathbf{F}$ had worked directly from $\mathbf{M}$, the scribe who added the Northumbrian annals to $\mathbf{K}$ worked only from $\mathbf{F}$. He ignored the dotted lines against the entries for $663 / 4$ and $668 / 9$, and transposed the entries for 668-670 down a year.

'The annals in $\mathbf{K}$ represent the latest and 'official' version of the early annals associated with Fulda, tidied up perhaps to mark the election of Hrabanus as abbot. ${ }^{28} \mathrm{It}$ is significant for the historiography of Fulda and for the practice of history writing in eighth- and ninth-century Francia, that Anglo-Saxon annals of seventh-century Northumbria were copied there twice; Anglo-Saxon Easter tables had provided the inspiration and the 'architectural' context for the gathering of historical notes in aid of the collective memoria of one of the major monasteries of the Anglo-Saxon mission to Francia.

\section{Manuscripts of the Kentish annals}

The Anglo-Saxon annals in the remaining four manuscripts share characteristics that suggest that they were derived from a different exemplar from that which supplied the Fulda group. ${ }^{29}$ These manuscripts share the Northumbrian references to the deaths of Aidan and Finan, and to the eclipse in 664 (here abbreviated to a single word), but they omit the annals on Colman, Ecgfrith and Osred, and add another entry to record the beginning of Oswiu's reign in 643. More significantly, three of the four copies incorporate Kentish annals concerning the deaths of Archbishop Theodore and the kings of Kent from Ethelberht to Eadric. No single manuscript contains all of the Kentish annals

Fakultät 7 (Frankfurt, 1996), 249-84, at 258-9; Corradini, 'Rhetoric of Crisis', pp. 278-81; idem, 'Zeiträume - Schrifträume', pp. 138-40. Prinz, Corıejer Alnalen, p. 15, mistepresents the early annals from $\mathbf{K}$ and $\mathbf{F}$, reading for example Heraclie for bora die in $\mathbf{K} 663$, and omitting the entries for 663, 668 and 669 from $F$, and 670 from $K$.

27 The DTR in this manuscript $(10 \mathrm{r}-84 \mathrm{v})$ was copied from an Insular exemplar, and contains marginal glosses in Insular minuscule concerning computistical, historical, grammatical, pedagogical and patristic themes; Corradini, 'Rhetoric of Crisis', p. 279, at n. 41.

28 Corradini, 'Rhetoric of Crisis', pp. 290-1.

29 Levison, England and the Continent, p. 274, at n. 2; D. Whitelock, After Bede, p. 8. 
and none of the extant manuscripts can have acted as the source for the others. The same three manuscripts share an additional set of Carolingian annals for the years 782-97 which notes the places where Charlemagne resided for the Easter celebrations in those years; the connections between the texts in these manuscripts thus extends beyond the Anglo-Saxon material. ${ }^{30}$ We cannot tell, however, whether the Kentish and Northumbrian annals were brought together in a manuscript that was copied in England and subsequently exported to Francia, or whether a Frankish scholar was responsible for bringing together the annals from the two Anglo-Saxon kingdoms.

\section{Verona, St Amand and Saliburg}

Two sets of Easter tables in this group were copied c. 800, namely, Berlin, Deutsche Staatsbibliothek, Phillipps 1831 (Rose 128), fols. 8-14 (Verona, s. ix ${ }^{\text {in }}$ / c. 800; provenance Metz) ${ }^{31}$ and Würzburg Universitätsbibliothek, M. p. th. f. 46, fols. 2-21 (St Amand, s. ix ${ }^{\text {in }} /$. 800; provenance Salzburg after 828, Würzburg after 976). ${ }^{32}$ The Würzburg manuscript (W) includes the five earliest Kentish and Northumbrian annals concerning kings $\mathbb{E}$ Ethelberht and Eadbald

30 That is, W, P1 and P2. The authorship of the entries concerning Charlemagne's Easter locations was attributed by Pertz to Alcuin, for no reason other than they correspond to the years that he was close to the Carolingian court; they were edited by Pertz, MGH SS 1, p. 86. The list is incomplete in the two Paris manuscripts, and the chronology of some events has slipped. The dislocation of the entries in both Paris manuscripts is explicable by comparison with the layout of the entries on $15 \mathrm{r}$ of $\mathrm{W}$ (where the entries are written around notes on Roman emperors, and supplemented by Salzburg notes) and it is likely that the list of Charlemagne's Easter venues in the two Paris manuscripts was copied from the exemplar which supplied these entries to $W$, if not directly from $W$ itself.

31 Bischoff, Katalog I, no. 437, p. 92; idem, 'Italienische Handschriften des 9. bis 11. Jahrhunderts in frühmittelalterlichen Bibliotheken außerhalb Italiens', Atti del Contegno Internazionale Il Ljbro $e$ il Testo, ed. C. Questa and R. Raffaelli (Urbino, 1984), pp. 169-94, at p. 174; V. Rose and F. Schilmann, I'ereichlniss der Lateiniscben Handsclinften der Königlicben Bibliotbek z" Berlin, Vol 1. Die Meerman-Handschriften des Sir Tbomas Pbillipps (Berlin, 1883), pp. 280-9; J. Kirchner, Bescbreibenders Ierzeichnis der Minialuren und des Initialschmuckes in der Pbillips-Handsclbiften (Leipzig, 1926), pp. 9-10 and pl. 12; Jones, 'Handlist', no. 13; Stevens, 'Handlist', p. 40; Laistner and King, Handlist, p. 148; $\Lambda$. Borst, Der karolingische Reicbskalender and seine Überlieferung bis ins 12. Jabrbundert, MGH Libri Mcmoriales 2, 3 vols. (Hanover, 2001), 100-2 and pls. 6 and 7 (2r-2v); P. Mcyvaert, 'Discovering the Calendar (Anualis Libell/us) Attached to Bede's Own Copy of De Temporum Ratione', $A B 120$ (2002), 5-64 at 14.

32 Lowe, CLA IX.1413; Bischoff, Sïdosidentscben Scbreibscbulen II, no. 104, pp. 133-4; H. Thurn, Die Handscbriften der Universitätsbibliotbek WT̈̈raurg: Die Pergamentbandscbriften der ebemaligen Dombibliotbek (Wiesbaden, 1984), pp. 34-6; Laistner and King, Handlist, p. 151 where the book is dated AD 792-807; Molinièr, Sources de l'bistoire, p. 218, no. 697; Stevens, 'Handlist', 40. On the oath of Leo III on 149r in the same codex, see L. Wallach, "The Genuine and Forged Oath of Pope Leo III', Traditio 11 (1955), 37-63 at 56-63, repr. in his Diplonsatic Studies in Latin and Greek Documents from the Carolingian Age (Ithaca, NY, 1977), pp. 299-327. 


\section{The Frankisly Annals of Lindisfarne and Kent}

or the others. in annals for ided for the exts in these cannot tell, ere brought ;ubsequently le for bring-

mely, Berlin, Terona, s. ix ${ }^{\text {in }}$ : M. p. th. f. after 828, five earliest ind Eadbald

e's Easter locaind to the years is 1, p. 86. The me events has by comparison ound notes on hat the list of the exemplar

1. Jahrhunderts azionale Il Libro $V$. Rose and $\mathrm{F}$. erlin, Vol 1. Die ; J. Kirchner, ps-Handscbriften andlist', p. 40; I seine Überliefer30-2 and pls. 6 ched to Bede's

14; H. Thurn, 1 der ebemaligen where the book ndlist', 40. On d Forged Oath ties in I atin and of Kent and Oswiu of Northumbria, and bishops Aidan and Finan of Lindisfarne. The first three of these annals are not found in any of the manuscripts associated with Fulda, and that concerning the burial of Eadbald is unique to W (pl. II). The scribe added the single word eclipsis alongside the year 664 , but mentions neither the departure of Colman nor the burial of Earconberht of Kent in the same year.

The copy of the Easter tables in the manuscript now in Berlin (B) shares with W the entries on the accession of Oswiu in 643, the death of Finan in 658 and the eclipse in 664, but has no other Anglo-Saxon entries among an otherwise extensive series of notes concerning mostly Roman and Byzantine emperors. ${ }^{33}$ $A$ few Carolingian notes were added to this imperial chronology by a second hand, and an eleventh-century scribe added annals for 934-1039 - with many relating to S. Vincent in Metz - to $106 \mathrm{v}$, separate from the Easter tables. Other features of $B$, however, confirm its affiliation to $W$ rather than the Fulda-group; the two volumes, $\mathbf{W}$ and $\mathbf{B}$, have copies of the $D T R$ that are more closely related to each other than to any other copy of that text. ${ }^{34} \mathbf{B}$ is an important computistical collection; in addition to the $D T R$, it contains the only surviving copy of a Frankish manual compiled in 737 that explained for an audience of children and laity why it was that the Easter calculations of Dionysius (the Greek Easter) were to be preferred to those of Victorius (the Latin Easter). This manual had an important influence on the development of the debates on chronology in eighth-century Francia and indicates that the introduction and acceptance of the Dionysiac system in Francia was not entirely dependent on the computistical

33 The entry concerning the 664 eclipse is added in the margin of $\mathrm{B}$ by the main hand of the table; the other annals are added by a second hand. 'Adnotationes antiquiores' (above, p. 63, n. 14); the imperial list goes up to the reign of Philippus (712) but may have continued to the beginning of the reign of Lco III, the Isaurian (717-41) as in Bede's Chronica maiora (ch. 66 $D T R)$; however the manuscript is torn at that point.

${ }^{34}$ They are part of Group Ia in Jones's edition; 'Handlist', nos. 13 and 242. Linked to these is the copy of the DTR in Leiden, Bibliotheek der Rijksuniversiteit, Scaliger 28 (Flavigny; s. $\left.\mathrm{ix}^{1 / 4}\right)$, which is Jones's no. 82 and Stevens, 'Handlist', p. 40. This manuscript contains Easter Tables only up to 1006 , and marginal calculations correlating the years $A D$ with the $A m m$ s Mundi chronologics devised by Euscbius (to 789) and revised by Bede as far as 806 (which may indicate a terminus post quem for the scribe). Both these features indicate some eschatological anxietics on behalf of the scribe; Wallis, Reckoning of Time, p. 363. Scaliger 28 also has an extensive series of Roman, Byzantine and Frankish annals which some have argued are written in the hand of the main scribe of the tables to 816 , on which, see $R$. McKitterick, "Constructing the Past in the Early Middle iges: the Case of the Royal Frankish Annals', TRHS 6th ser. 7 (1997), 101-29, at 112-13; R. Landes, 'Lest the Millenium be fulfilled: $\lambda$ pocalyptic Expectations and the Pattern of Western Chronography 100-800 CE', The Use and Abuse of Eschatology in the Middle Ages, ed. W. Yerbeke, C. Yerhelst, A. Welkenhuysen, Mediaevalia Lovaniensia Scr. 1/Studia 15 (Leuven, 1988), 137-209, at 188-9. 


\section{Joanna Story'}

works of Bede. ${ }^{35}$ The volume also contains the best extant copy of the ' $\mathrm{A}$ ' version of the Carolingian Encyclopaedia on Time that was produced in 793, perhaps at Verona where this manuscript was made, and which acted as a precursor to the ' $\mathrm{B}$ ' version compiled at Aachen in 809. 'The text of the encyclopaedia in our Berlin manuscript draws on Bede's DTR but does not cite him by name, even though a full copy of that text is included earlier in the same volume on $16 \mathrm{t}-89 \mathrm{v}^{36}$ This copy of the DTR is preceded by a calendar (as well as the Easter tables) which is among a group considered by Meyvaert to be very close to Bede's own astronomical calendar. ${ }^{37}$

The Würzburg copy of the Easter tables was made probably at St Amand in north-east Francia, early in the ninth century. The script is typical of the style developed during the career of Alcuin's friend Arn as abbot of St Amand and bishop of Salzburg (783-821, bishop from 785, archbishop from 792), and the annus praesens on $89 \mathrm{r}$ in ch. 49 of the DTR is given as DCCC. ${ }^{38} A$ Salzburgtrained scribe added the Cloronica maiora and the remaining chapters of the DTR (chs. 66-71, fols. 98v-144v) some time after 821 (perhaps while the manuscript was still in St $A$ mand), and around 828 the manuscript was taken to Salzburg where annals concerning Salzburg and Bavaria, as well as wider Frankish issues, were added to the Easter tables by a number of different scribes. ${ }^{39}$ 'The AngloSaxon entries, however, are in the same hand as the Easter tables and seem to

${ }^{35}$ The unique copy of the text is on $138 \mathrm{r}-142 \mathrm{r}$. B. Krusch, 'Das älteste fränkische Lehrbuch der dionysianischen Zeitrechnung', Melanges offerts a Emile Chatelain (Paris, 1910), pp. 232-42; $\Lambda$. Borst, 'Alkuin und die Enzyklopädic von 809', Science in W"estern and Eastern Civilization in Carolingian Times, ed. P. L. Butzer and D. Lohrmann (Basel, 1983), pp. 53-78; On the relative importance of Bede's chronological treatises in Francia, sec McKitterick, "Constructing the Past', p. 109, with the case restated and tcinforced in her History and Memory in the Carolingian Irorld (Cambridge, 2004), pp. 946.

36 The 793 ' $N$ ' version of the Encyclopacdia is found on 116v-125v; Borst, 'Alkuin und die Enzyklopädic', pp. 53-78; Borst, Karolingische Kalenderreform, pp. 317-18; Corradini, 'Zeiträume - Schrifträume', pp. 122-3.

37 The calendar in this volume has several additions relating to the cult of $S$. Zeno who was vencrated in Verona; Meyvaert, 'Discovering the Calendar', p. 37; Borst, Reiclskealender, pp. 100-3.

38 Wallis, Reckoning of Time, pp. lxxxix, at n. 253, and 130. On the reading and writing of history at St $\lambda$ mand, see McKitterick, History and Memor', pp. 210-17, and H. Reimitz, 'Ein karolingisches Geschichtsbuch aus St $\lambda$ mand. Der Codex Vindobonensis palat. 473', Text-Sclbrift - Codex: Quellenkundlicbe Arbeiten aus den Institut fir Österreicbische Geschicbtsforschung, ed. C. Egger and H. Wieigl, Mitteilungen des Instituts für Österreichische Geschichtsforschung, Ergänzungsband 35 (Munich, 2000), 34-76. On the connections between the scriptoria at St $A$ mand and Salzburg during Arn's tenure of both places, sce Bischoff, Sïdostdentschen Sclireibscbulen, pp. 53-161.

39 W. Wattenbach, W'. Levison and H. Löwe, Dentstblands Gescbichtsgtrellen im Mittelalter (Weimar, 1953), pp. 190-1; Bischoff, Sïdostdentscben Scloreibscbulen, p. 134; Thurn, Handsclinffen, p. 34. On the Amales Inratenses maiores, see MIGH SS 1,86-9; MGG SS 3, 122 (which gives the annals in the left hand margin) and MGH SS 30.ii, 727-44, where Bresslau identified the author/scribe as Baldo the Fat. 


\section{The Frankish Annals of Lindisfarne and Kent}

' of the ' $A$ ' iced in 793 , ed as a pre$f$ the encylot cite him $\mathrm{n}$ the same dar (as well t to be very

$t$ Amand in of the style Amand and 12), and the Salzburgof the DTR manuscript o Salzburg kish issues, The Angload seem to

Lehrbuch der ग. 232-42; $A$. Cinilization in $\mathrm{n}$ the relative structing the be Carolingian kuin und die ; Corradini,

who was venr, pp. 100-3. ig of history in karolingisbrift - Codex. igger and $\mathrm{H}$. inzungsband Amand and ibschulen, pp.

lier (Neimar, $e n$, p. 34. On the annals in thor/scribe have been copied at the same time as the tables probably at St Amand. Again, as in Fulda, this manuscript shows that the copying of the Anglo-Saxon Easter table annals in Francia encouraged the recording of events local to the monastery that owned it.

\section{Alscerre}

- Two more copies of the annals were made in Francia before about 830, both apparently at the monastery of St Germain at Auxerre. These are now Paris, Bibliothèque nationale de France, lat. 13013, 8v-18r (Auxerre, c. 830; provenance St Germain-des-Près), hereafter $\mathbf{P 1},{ }^{40}$ and Paris, Bibliothèque nationale de France, Nouv. acq. lat. 1615, 10r-18v (Auxerre, c. 830; provenance Fleury), hereafter P2. ${ }^{41}$ They contain the same selection of Northumbrian annals as $\mathrm{W}$, adding the reference in 664 to the departure of Colman from Lindisfarne. Both copies have, correctly, Colman abiit, which indicates that their exemplar was not one of the Fuldan copies of the annals where abiit was misread and copied as obiit but rather a copy - more like $\mathbf{M}$ - that retained the correct reading. Both manuscripts contain Kentish annals but these must have been derived from a common source rather than one from the other. They share the Kentish entries for 673-690 but P1 adds the entry for the death of $/$ Ethelberht (which it shares with $\mathrm{W}$ but not P2), and P2 includes a unique entry s.a. 664 for the burial of Earconberht and adds the day of the week to the record of the death of Hlothhere in $685 .^{42}$ Neither has the entry for 640 on the death of Eadbald that is unique to $\mathrm{W}$.

$\mathbf{P 2}$ includes an abbreviated chronicle later in the volume on $171 \mathrm{v}-172 \mathrm{r}$, which is known from a number of ninth-century manuscripts and counts the number of years from Adam to the 'present day', being the forty-second year of the reign of Charlemagne and the ninth of his imperial rule, that is, late in

40) Intentaire de manuscrits latins conseriés à la Bibliothèque Nationale sous les numéros 8823-18613. Pt II. Intentaire des manuscrits de Saint-Germain-des-Prés (Paris, 1868), p. 84. The Amales Lindisfarmenses, Cantuarienses, Sancti Germani minores from this manuscript are edited by G. H. Pertz, MGH SS 4 (Hanover, 1846), 1-4. Sec also Wattenbach and Levison, Deutscblands Gescbicbtsquellen, p. 190; Molinièr, Sonrces de l'bistoire, no. 711; Levison, England and the Continent, p. 274; Stevens, 'Handlist', p. 40; Borst, Reiclskkalender, pp. 148-50 (sighm/ c 4, 2r-8r).

" L. Delisle, Catalogme des manuscrits des Fonds Libri et Barrois (Paris, 1888), pp. 70-6; Stevens, 'Handlist', p. 41. The calendar that precedes the Easter 'Tables in P2 (3r-9v) includes some Anglo-Saxon entries such as the burials of Cuthbert (20 March), Bede (26 May), Paulinus of York (10 October); Borst, Reichskalender, pp. 143-5 (siglum c 1).

42 In the annal for 673, P2 substitutes Cantia rex for the more usual Cantuariormm rex. On the different styles, see Charters of St Angustine's Abbey, Canterbury and Minster-in-Thanet, ed. S. E. Kclly, $A$ S Charters 4 (Oxford, 1995), p. lxxvii, and A. Scharer, 'Die Intitulationes der angelsächsischen Könige im 7. um 8. Jahrhundert', Intitulatio III: Lateinische Herrschertitel und Herscbertitulaturent tom 7. bis z"lm 13. Jabrbundert, Mitteilungen des Instituts für Österreichische Geschichtsforschung, Ergänzungsband 29 (1988), 9-74, at 39-48. 


\section{Joanna Story'}

$809 .{ }^{43}$ The author also provides the annus mundi (AM 4761), according to Bede's recalculation as explained in the DTR rather than the Eusebian chronology (AM 6009). This agrees with the conclusions of the Carolingian calendrical Encyclopaedia of 809 , which declared that Bede's recalculation was correct thus deferring the eschatological complexities associated with the ending of the Age of Christ in AMI $6000 .{ }^{4+}$ The manuscript also has, on $143 \mathrm{v}-144 \mathrm{v}$, a copy' of a report from 809 of a discussion among a group of Carolingian scholars about computus, drawn up perhaps by $A$ dalhard of Corbic. ${ }^{45}$ Like $W$ and $\mathbf{B}$, the annals in $\mathbf{P 1}$ and $\mathbf{P} 2$ incorporate the Roman and Byzantine list of emperors up to the eighth year of the reign of Leo III (717-42), and both add a list of Charlemagne's Easter venues (782-792/4) derived from W or its exemplar. P2 has no further Frankish information and is the only one of our set that did not inspire the collection of annals local to the monastery where it was kept. P1, however, adds a set of brief Frankish annals for the years 642-793 (in the hand of the main scribe of the tables), followed by annals for the ninth century that show an increasing interest in the Paris region. These are continued until 1146 and are known as the Amales $S$. Germani minores. ${ }^{46}$

\section{Manuscript summary: Easter tables and the bistorical record}

The manuscript evidence for the 'Frankish' Annals of Lindisfarne and Kent demonstrates that our earliest copy of these annals, $M$, predates the earliest extant copy of the Anglo-Saxon Clbronicle by about 150 years, and may be considered our earliest surviving Anglo-Saxon annalistic manuscript. ${ }^{47}$ These annals and these manuscripts thus have an important place in English historiography, not least in the 'chicken and egg' debate concerning the place of paschal annals in the formation of the historical record in Anglo-Saxon England. ${ }^{48}$ In this respect it is also significant that the copies of the English annals made in Francia attracted further marginal annals which concerned events of national significance to the Frankish kingdom as well as annals more

43 'Chronica de sex aetatibus mundi', ed. Pertz, MGH SS 2 (Hanover, 1829), 256. See also, 'Generationum regnorumque laterculus Bedanus cum continuatione carolingica altera', ed. 'T. Mommsen, MGH Auct. antiq. 13 (Berlin, 1898), 346-54.

" J. Heil, "Nos nescientes de hoc velle manere" - "We Wish To Remain Ignorant $\lambda$ bout This". Timeless End or $\Lambda$ pproaches to Reconceptualising Eschatology after $\Lambda \mathrm{D} 800$ ( $\Lambda \mathrm{M} 6000)$ ', Traditio 55 (2000), 73-105. On the Encyclopacdia of 809, see Borst, 'Alkuin und die Enzyklopädie', pp. 53-78. $\quad$ 45 Wallis, Reckoning of Time, p. lxxxix (at n. 246).

46 'Annales Lindisfarnenses, Cantuarienses et Sancti Germani minores', ed. Pertz, MGH SS IV, (Hanover, 1846), 3-4.

47 The Anglo-Saxon Chronicle $M S A$, ed. J. Batley, The $\Lambda$ S Chronicle: a Collaborative Edition, $\mathrm{ed}$. D. Dumville and S. Keynes 3 (Cambridge, 1986).

ts For example, Poole, Cbronicles and Amnals, pp. 27-34; M. McCormick, Les annales du bant moyen age, Typologie des Sourecs du Moyen Age Occidental (Turnhout, 1975), pp. 13-24; M. Lapidge, 'Annals', Engrlopaedia of Anglo-Saxion England, ed. I apidge et al., pp. 39-40. 


\section{The Frankish Annals of Lindisfarne and Kent}

g to Bede's hronology calendrical vas correct ending of $3 \mathrm{v}-144 \mathrm{v}$, a Zarolingian e. ${ }^{45}$ Like W itine list of $\mathrm{d}$ both add I W or its one of our ry where it : the years annals for .. These are es. ${ }^{46}$

and Kent the earliest lay be cont. ${ }^{47}$ These ish historiic place of nglo-Saxon he English concerned nnals morc

256. See also, altera', ed. T.

About This". I (AM 6000)', suin und die

MGH SS IN, e Edition, ed. specifically related to particular Frankish monasteries. The copies from Fulda ( $F$ and $\mathbf{K}$ ) and St Amand (W) are among the earliest extant Carolingian annalistic manuscripts and thus they also hold an important position in Carolingian historiography. ${ }^{49}$

In Frankish, as in Anglo-Saxon, historiography it has long been assumed that paschal annals represent the most 'primitive' form of historical record, and that longer and more detailed chronological narratives (such as the Anglo-Saxon Chronicle or the Annales regni Francormm) evolved from the concept of a year-by'year record established by brief marginal notes alongside Easter tables such as those in our manuscripts discussed here. ${ }^{50}$ Furthermore, it has been argued that paschal annals stimulated the production in Francia of 'minor' sets of annals, which often displayed an interest in the events of a particular region or community and which themselves provided the inspiration and material for the 'official' sets of annals produced at the court. Rosamond McKitterick, revising her views, has recently argued against this long-held hypothesis, arguing instead that the minor annals were produced in response to the court-centred construction of a 'national' (Carolingian) historical narrative that was first put together in the late $780 \mathrm{~s}^{51}$ She has argued also, partly on the date of particular manuscripts, that paschal annals produced in individual monastic houses around Francia were part of this response; a reaction rather than a prompt to the formation of a centralized dynastic narrative.

Our manuscripts demonstrate that historical notes about past events in England were being copied, certainly in Fulda, before the end of the eighth century, and that before 800 annals concerning contemporary Frankish events of kingdom-wide significance were being copied into the same manuscripts as well as entries of concern to the monasteries in which the books were kept. Several of our manuscripts are comparable in date to the earliest surviving manuscript of extended Frankish annals, Vienna, Österreichische Nationalbibliothek, cod. 515 (Alemannia, c. 800; provenance Reichenau by 835), which contains the Amales Laureshamenses for the years 794-803, written up by four

49 The ongoing work of Richard Corradini and Helmut Reimitz in Vienna on manuscripts containing historical texts and 'minor' annals such as these demonstrates their importance in the construction and maintenance of community identities in Carolingian Francia.

50 Wattenbach and Levison, Deutscblands Gescbichtsquellen, pp. 180-3; L. Halphen, Etudes rritiques sur I'histoire de Charlemagne (Paris, 1921), pp. 16-59; H. Hoffmann, Untersuchungen zur karolingiscben Annalistik, Bonner historische Forschungen 10 (Bonn, 1958), 69-75; Ganshof, 'L'historiographie', pp. 665-76; R. McKitterick, The Frankish Kingdoms under the Carolingians, 751-987 (London, 1983), pp. 2-7.

il McKitterick, 'Constructing the Past', pp. 110-14, expanded and revised in her History and Memor', pp. 20-2 and 97-104, with a useful summary of the historiography of Frankish annalistic compositions. The earliest extant manuscript of the Amnales regni Francortm dates to the reign of Louis the Pious, Cologne, Sankt Maria in Kapitol, AII/18, s. ix ${ }^{1 / 3}$ (post 824); ibid. pp. $20-2$. 


\section{Joanna Story}

different scribes in short stints that are very nearly contemporaneous with the events they describe. ${ }^{52} \mathrm{~A}$ study of this material shows us, at the very least, that the two forms of annals were being produced simultaneously; the longer, more literary annals, free of the constraints of the tabular framework of the Easter table, were being written up in a monastery in Alemannia at the same time as Easter table annals were being copied and composed at Fulda, St Amand, and perhaps Werden too.

It is probably wrong to think of the Easter tables annals as being the more antiquated structure; the two forms of historical writing served different purposes. The Amnales Lauresbamenses and other 'minor' annals like them provided a forum for the development of a nuanced, narrative account of Carolingian history; the Easter tables provided a rigid structure that linked the Frankish present to the whole of the Christian past, and provided systematic chronological stepping-stones back via the emperors of old to the birth (and death) of Christ himself. Uniquely, as a form of historical expression, the tables also provided a route to the future, since they contained not only the ghosts of Easters past but also those of Easters-yet-to-come.

THE CONTENT OF THE ANNALS

\section{Bede, Boniface and Alcuin}

The seven sets of Easter tables in these manuscripts contain between them thirteen entries concerning seventh- and early-eighth-century England. The earliest entry refers to the death of Ethelberht, the first Christian king of Kent, and the last to the accession of Osred of Northumbria s.a. 704. Some of the manuscripts contain additional notes concerning Anglo-Saxons, namely records of the deaths of Bede in 735, Boniface in 754 and Alcuin in 804. But these three entries are of a different character from those of the

52 The attribution of the annals to Lorsch is misplaced and derives from an assumption that the prominence given to Lorsch in the text was an indication of its origin. These annals are particularly important as they offer an alternative view of the events surrounding Charlemagne's impcrial coronation in 800 to that disseminated by the Amnales regni Francorum., see Das IVTener Fragment der Lorscher Annalen, Clbristus und die Samariterin. Kateclese des Niceta ton Remesiana. Codex I Indobonensis 515 der Österreichiscben Nationalbibliotbek Facsimile Ausgabe, ed. F. Unterkircher, Codices Sclecti 15 (Graz, 1267); Irblich, Karl der Grosse und die IVissenscbaft, no. 3, pp. 40-1; McKitterick, Histog' and Memory', pp. 104-11; R. Collins, 'Charlemagne's Imperial Coronation and the Annals of Lorsch', Charlemagne: Empire and Socieb', ed. J. Story (Manchester, 2005), Pp. 52-70. $A$ full, later copy of the Amales Lauresbamenses survives as Benediktinerstift $\mathrm{St}$ Paul in Lavanttal, Stiftsarchiv cod. 8/1 (s. 835, Richenau), on which see C. Steigemann and M. Wemhoff, 799 Kunst und Kultur der Karolingerzeit. Karl der Großie und papst Leo III. in Paderborn, 2 vols. (Mainz, 1999), II.3, 38-40. The only other text in that manuscript (most of which has been lost) are Easter Tables covering the years $777-835$ which, unusually, use the calculations of Theophilus of Alexandria. 


\section{The Frankish Annals of Lindisfarne and Kent}

as with the least, that nger, more the Easter me time as mand, and $\mathrm{g}$ the more ferent pur$n$ provided Jarolingian e Frankish ic chronod death) of s also proof Easters

ween them gland. The an king of 704. Some lo-Saxons, 1 Alcuin in ose of the tion that the inals are parharlemagne's se Das Il'iester yesiana. Codex Unterkircher, 3 , pp. 40-1; 1 Coronation er, 2005), pp. tift St Paul in zann and $M$. "Paderborn, 2 of which has e calculations earlier group, and should be considered separately. Notice of the martyrdom of Boniface is found, as might be expected, in the two Fulda manuscripts, $F$ and $\mathrm{K}$, along with other annals relating to the foundation and history of Boniface's monastery there; the annal is thus considered part of the first redaction of the Ammales Fuldenses antiquissimi. ${ }^{53}$ A letter of condolence from Bishop Milred of Worcester to Lul indicates that news of Boniface's death had reached England quickly, but given the Fuldan provenance of these manuscripts it is unnecessary to suppose that the annal was re-exported from England to Fulda. ${ }^{5+}$ There are no Fuldan entries in the margins of the Northumbrian portion of $\mathbf{M}$ (though tables 12 and 13 for the years 741-78 are lost) nor in the quire that was added to it at Fulda; this may indicate that $M$ left Fulda shortly after the additional quire was added or that it was superseded there by $\mathbf{F}$, which had recently been copied by the same scribe as that which had added the second gathering of Easter tables to $\mathbf{M}$. Likewise, it is no surprise to find reference to the death of Alcuin in a manuscript from St Amand and Salzburg (W); its location in that manuscript reflects the close friendship between Alcuin and Arn, abbot of St Amand and archbishop of Salzburg, rather than a continuation of the interest in Anglo-Saxon history evident in earlier annals in the same book.

Notice of the death of Bede, however, is a commonplace in Frankish annalistic manuscripts and is found widely beyond this group of books. ${ }^{53}$ This reflects the popularity of Bede's works in the Carolingian schools and the reference was often copied independently of any other notices of Anglo-Saxon history. Letters from Boniface and his successor Lul ( $\uparrow 786)$ to WearmouthJarrow and York requesting copies of Bede's works illustrate a non-annalistic mechanism by which news of the date of Bede's death may have reached Francia. ${ }^{56}$ Cuthbert's Epistola de Obitu Bedae was also in the hands of Frankish readers in the eighth century; the copy in the Hague manuscript contains a

53 Amales Fuldenses antiquissimi, ed. Pertz, MGH SS 1, 95; MGH SS 3, 116*-17; Corradini, 'Zciträume - Schrifträume', p. 144 (the first redaction goes from 744-78). The $A E A$ are also found in ÖNB Cvp. 460 (pars II), 790-820 (Fulda), above, p. 66, n. 25.

5t S. Bonifatii et Lullii Epistolae, ed. M. Tangl, MGH Epp. Sel. 1 (Berlin, 1916), no. 112, pp. 238-4; The Letters of Saint Boniface, trans. E. Emerton (New York, 1940), pp. 187-9.

55 The annal is in F (37v), K (4r), and P1 (12v; s.a. 737). It is also found in, for example, the texts known as the Anmales Ifosellan;, ed. I. M. Lappenburg, MGH SS 16 (Hanover, 1859), 492; the Amales Alemannici and the Amales Nazarini, ed. G. H. Pcrtz, MGH SS 1 (Hanover, 1826), 24-5; the $A$ innales Sangallenses breves et maiores, ed. G. H. Pertz, MGH, SS 1 (Hanover, 1826), 64 and 73; Annales Argienses, ed. G. H. Pertz, MGH SS I (Hanover, 1826), 67. It is also in the Continuation to the $H E$, known only from a group of twelfth-century manuscripts from the lower Rhine region, Bede's Ecclesiastical History of the English People, cd. B. Colgrave and R. A. B. Mynors, ONT (Oxford, 1969), pp. lxvii-lxix and 572-3.

56 S. Bonifatii et Lullii Epistolae, ed. Tangl, no. 75-6 and 91, pp. 156-9 and 206-8; Letters of Saint Boniface, trans. Emerton, pp. 132-4 and 167-9. 
prefatory letter addressed to Albinus, perhaps to be identified as one of Boniface's Anglo-Saxon assistants who became the bishop of Büraburg, near Frizlar, Hesse in 741 or $742 .{ }^{57}$ The continental versions of the Epistola contain the original Northumbrian version of Bede's Death Song, rather than the later West Saxon version that survives in the later English copies of the text. ${ }^{58}$ The date of Bede's death may thus have had an independent route of transmission into our manuscripts, separate from the other Anglo-Saxon annals. But it is just possible that the reference to Bede's death in 735 had also originally been in $\mathbf{M}$ since it Is included in the two Fuldan copies of our annals, $\mathrm{F}$ and $\mathrm{K}$, which are derived from it; however, the loss in $\mathbf{M}$ of most of table 11 covering the years $722-40$ makes this impossible to verify. ${ }^{59}$

\section{Imperial Rome and Byzantitum}

The Anglo-Saxon annals in all our manuscripts are embedded within a variety of other historical notes concerning, variously, the reigns of Roman and Byzantine emperors and Frankish political history, as well as events of local interest to particular Frankish monasteries. In the early part of the series we have references to the accession of Roman and Byzantine Emperors from the accession of Tiberius in AD 13 to the eighth year of the reign of Leo III, the Isaurian (717-41). Here we are looking at a palimpsest of Great Cycles where notes accompanying the first complete $\mathrm{Great} C y$ cle from the year preceding Christ's birth to 531 underlie the second Great Cycle from 532 to $1063 .{ }^{60}$ Thus, for example, the accession of Antoninus Pius in the year 137 and the length of his rule is found alongside the entry for the year 669 (669 minus $532=137$ ); in $M$ this entry, ANTON[INUS] PIUS XX III, sits below the reference in 668 to the accession of the Byzantine Emperor Constantine IV, CONSTANTIN[US] XVII, and above the annal recording the accession in 670 of Ecgfrith, king of Northumbria, + ECGFRID REGN[ARE] COEPIT.

It is important to note that Roman and Byzantine references are included in the uncial section of $\mathbf{M}$, indicating that the Northumbrian annals arrived in

${ }^{57}$ The Hague, Koninklijke Bibliotheek, 70. H. 7, fols. $42-65$ (s. $\left.x^{\text {in }}\right)$; N. R. Ker, "The Hague Manuscript of the Epistola Cutbberti De obitu Bedae with Bede's Song', ILE 8 (1939), 40-4. For the identification of Albinus as the bishop of Büraburg rather than Alcuin, see P. SimsWilliams, Religion and Literature in I"estern England, 600-800, CSASE 3 (Cambridge, 1990), pp. $353-4$.

${ }^{38}$ Epistola Cutbberti De obitu Bedae, ed. Colgrave and Mynors, Bede's Ecclesiastical Histor, pp. 579-87; E. van K. Dobbie, Caedmon's Hymm and Bede's Death.Song (New York, 1937); R. Sharpe, Handlist, no. 212. ${ }^{59}$ Corradini, 'Zeiträume - Schrifträume', pp. 141-4.

(s) In W the original scribe put some of the imperial entries from the second $C_{y}$ cle in the lefthand margin, and a later scribe added a note, or [do] $i i$, to avoid confusion with the entries from the first. Unsurprisingly; the imperial chronology in these tables has sometimes slipped by a year or two; E. J. Bickerman, Cbronology of the Ancient ll"orld (London, 1968), pp. 193-5. 


\section{The Frankish Annals of Lindisfarme and Kent}

s one of urg, near 'a contain 1 the later xt. ${ }^{58}$ The ismission It it is just eeen in $\mathbf{M}$ which are the years

a variety man and s of local series we from the :O III, the les where preceding $3 .^{60}$ Thus, length of $=137)$; in in 668 to JTIN[US] $h$, king of scluded in arrived in

'The Hague 1), 40-4. For jee P. Simse, 1990), pp.

History, pp. ); R. Sharpe, $:$ in the leftentries from slipped by a 193-5.
Francia embedded in this wider world history that stretched back to the beginning of the Christian Era. This arrangement implies that the author of the Easter table annals as found in $\mathbf{M}$ was working with a full Great Cycle of 532 years, and had understood that it was truly cyclical and could be projected backwards to the year before the birth of Christ, thus permitting the events of the first 531 years of the Christian Era to be set alongside the tables for the next 532 years. ${ }^{61}$ Bede explained the phenomenon of the 532-year cycle in chapter 13 of his first work on time, De temporibus, that he finished in 703 but in his later treatise De temportm ratione (DTK) of 725 he expanded his analysis to explain how the Great Cycle provided a framework for the course of human history. 'Thus', he says, 'whoever reads [the tables] can, with unerring gaze, not only look forward to the present and future, but can also look back at each and every date of Easter in the past, and in order to clarify an ancient text, he can clearly identify all the years since it is sometimes doubtful when and of what sort they were. ${ }^{62}$ This is the context for the transposition of the imperial chronology to the margins of the Easter table (and from the era AM to $\Lambda D$ ), and suggests a date of compilation of the set of annals in $\mathbf{M}$ after 725 when Bede had completed the DTR and the Great Cycle that accompanied it.

Indeed, all the Roman and Byzantine references in our annals are found in the world chronicle (Cbronica maiora) which is ch. 66 of the DTR. ${ }^{63}$ This was probably the source of imperial references accompanying our annals, rather than Eusebius's Kanones (translated and continued by Jerome, Prosper and others) that had supplied Bede with the same data. Levison and Lehmann assumed that the exchange had worked the other way around, and that Easter tables accompanied by an imperial chronology pre-existed the DTR and had been available to Bede and others in early eighth-century Northumbria. ${ }^{64}$ The last imperial entry in the Cluronica maiora notes that the Emperor Leo was in the

61 Marianus Scottus took this process a stage further in the elcrenth century, and began to add the events of the third great cycle, beginning in 1064 to his world chronicle (under a revised $\Lambda \mathrm{D}$ chronology).

62 DTR, ch. 65; Jones, Opera Didascalica, CCSI. 123B, p. 460; Wallis, Reckoning of Time, pp. 155-6 and $352-3$.

63 Mommsen, MGH $A$ uct. antiq. 13 (Berlin, 1898), 223-354; Opera Didascalica, ed, Jones, CCSL 123B, 463-535; Wallis, Reckoning of Time, pp. 157-237 and 353-66. Bcde included a smaller world chronicle, the Cbronica minora, in his De temporibus (cc. 16-22) which he completed in 703; Opera Didascalica, cd. Jones, CCSL 123C, 580-611, at 607-11. The imperial entries in our annals continue to 725 , which indicate use of the larger Clbronica maiora.

of Lehmann, Fuldaer Studien, pp. 34-46, where he notes that Wattenbach thought this compilation was the work of a monk in Lindisfarne, c. 700 - a reference to our manuscript, $\mathbf{M}$; Levison, England and the Continent, p. 270. Under this scenario, Bede would have translated the $A D$ dates of the tables into his revised $\lambda M$ chronology for the DTR. Levison's argument (at least) is underpinned by the assumption that paschal annals were familiar in England before Bede's day. 


\section{Joanna Story}

eighth year of his reign, that is, $A D 725 .{ }^{65}$ This is matched by the imperial entries in our manuscripts; those copies that include Leo III within the imperial chronology note only the first eight years of his rcign, as in the DTR. The beginning of Leo's reign is recorded in W, $\mathbf{P} 1$ and $\mathbf{P} 2$; it was probably once in $\mathrm{B}$ as well but the lower corner of folio 10 in that manuscript is torn and the entries for the end of table 10 (703-21) are missing. ${ }^{66}$

With the Fulda-group of manuscripts $(M, F, K)$ the evidence is more difficult. We know that the uncial portion of $\mathbf{M}$ contained imperial annals from both the first and'second Great Cycles, but because that part of the manuscript is now so fragmentary we do not know for how long the imperial annals continued. The gathering that was added to the uncial part of $\mathbf{M}$ in Fulda (containing tables 14-28, AD 779-1063) has no imperial annals at all among the multiplicity of Frankish entries in its margins. The copy of $M$ that was initiated at Fulda by the same scribe, and which is now in $\mathbf{F}$, as well as the later Fuldan copy now in $\mathbf{K}$, finish their run of imperial annals s.a.698/9 with the reign of Tiberius III who, they say, ruled for six years, that is, to 704 . This corresponds with the last Northumbrian entry in both manuscripts, which notes the beginning of the reign of Osred in 704. At first sight, this might be taken to imply that the source of the imperial annals was not the Clsronica maiora, completed with the DTR in 725 , but the Cbronica minora that was part of the De temporibus, which Bede completed in 703 with the note Tiberius deline quintum agit anmum ind. primum. ${ }^{67}$

However, not only are the imperial entries after 704 absent from $F$ and $K$, but so too are all of the imperial references from the first Great Cycle after the entry on table 9 for $A D 166 / 698$. Thus, both $F$ and $K$ have imperial entries from the first Great Cycle from the beginning of the reign of the Emperor Tiberius in AD 13 to Marcus Antoninus Verus (Marcus Aurelius) in AD 160 (corresponding to the years $A D 545$ and 692 in the second Great Cycle), and imperial entries for the second Great Cycle from the beginning of the rule of the Emperor Justin II in AD 565 to that of Tiberius III in 698; but the entries from the late second century through to the mid-sixth century are missing. ${ }^{68}$ This must imply that the exemplar of $\mathrm{F}$ and $\mathrm{K}$ was deficient. What it does not tell us is whether that exemplar, which we know to have been our manuscript $\mathbf{M}$, was incomplete when it arrived in Fulda and that the second gathering, made at Fulda, added tables $14-28$ to an otherwise incomplete or damaged text, or whether an uncial copy of tables 14-28 was replaced at Fulda by a gathering copied from another manuscript without the imperial entries, or if the Fuldan scribe, copying $\mathbf{M}$, simply chose to omit the imperial entries as irrelevant to his

${ }^{65}$ Chs. $49,52,54$ and 58 of the DTR also indicate a date of composition of 725 for the calculations in those chapters.

66 'Adnotationes antiquiores', ed. Mommsen, pp. 751-6. ${ }^{67}$ Lehmann, Fuldaer Studien, pp. 41-2. ${ }^{68}$ Ibid. p. 40. 


\section{The Frankish Amnals of Lindisfarne and Kent}

re imperial the impe$D T R$. The bly once in rn and the

re difficult. $\mathrm{m}$ both the it is now so inued. The ning tables Itiplicity of ulda by' the now in $\mathrm{K}$, us III who, th the last ing of the the source he DTR in Bede com'm. ${ }^{67}$

and $\mathrm{K}$, but e after the atries from or Tiberius 60 (correId imperial ule of the ttries from ing. ${ }^{68}$ This not tell us ipt $\mathbf{M}$, was 3 , made at d text, or I gathering the Fuldan vant to his or the calcur Studien, pp. needs. Any of these scenarios would explain why there are no imperial entries in $\mathbf{F}$ and $\mathrm{K}$ for tables 14-28 (779-1063) but none explains why the imperial entries after Tiberius III in 698 to 778 are absent from $F$ and $\mathrm{K}$ since we know that the uncial portion of $\mathrm{M}$ continued to at least 740 and probably to the end of table 13 in 778.

\section{Francia}

After the Anglo-Saxon entries finish in 704, further annals on Frankish affairs Were added to five of our seven copies of the Easter tables. Annals concerning Werden (809-40) and Corvey (791-1117) were added by several hands to M; the Annales Fuldenses antiquissini (744-838) were added in stages to $\mathbf{F}$ and $\mathbf{K}$; the Amales Inravenses minores (725-835) were added to W; and the Amnales Sancti Germani minores (642-1146) were added to P1. No further Frankish annals were added to the margins of the Easter tables in $\mathbf{B}$, but annals focused on $\mathrm{St}$ Vincent at Metz were added later in the volume in the eleventh century. Only P2, made in Auxerre c. 830 and later at Fleury, did not inspire the collection of local annals. But that manuscript shares with $\mathbf{P 1}$ and $\mathrm{W}$ the notes about where Charlemagne spent Easter between 782-97. The Frankish entries thus record events that were of wider significance to the whole Frankish people as well as events that were of local significance to the place where each manuscript was kept. Each of our seven copies is, therefore, in some senses an independent and distinct Frankish chronicle that has Anglo-Saxon annals and an imperial chronology' at its core.

This is not the place to offer a detailed analysis of the Frankish annals in these manuscripts but a few observations can be offered that are relevant to scholars of historical writing in Anglo-Saxon England. Firstly, the manuscripts reveal stages in the collection and consolidation of information relating to particular places over time and across redactions of the texts. Richard Corradini has shown this most clearly with the Amales Fuldenses antiquissimi that survive in our manuscripts $\mathrm{M}, \mathrm{F}$ and $\mathrm{K}^{69} \mathrm{He}$ has revealed the stages of the development of the text in these manuscripts, and has shown how the text of the Annales Fuldenses antiquissimi was consolidated at times of particular anxiety for the community at Fulda. The stages of composition preserved in $\mathbf{F}$ and $\mathbf{K}$, along with the palacography of the annals in $\mathbf{M}$ and another related manuscript Vienna, Österreichische Nationalbibliothek, cod. 460 (which contains the Annales Fuldenses antiquissimi but without the prefatory Northumbrian entries) are crucial to understanding how the monks at Fulda constructed the history and consolidated the identity of their own community at key points in the later

69 Corradini, 'Rhetoric of Crisis', pp. 278-90 and 295; idem, 'Zeiträume - Schrifträume', pp. $141-60$. 


\section{Joanna Story'}

eighth and earlier ninth century. The reworking of the brief historical notes was a vehicle for the affirmation of the collective menoria of that monastery; it is significant for us that the Northumbrian annals, copied twice in this process, remained a relevant part of that story.

The Salzburg material added after 828 to the Easter tables from St Amand (W) likewise show the process of consolidation of the history of that monastery set within the politics of the kingdom. That manuscript shows clearly; that information was added at different times by more than one scribe; they tried to organize their material, placing notes of events of local significance in the right hand margin, and those relating to the whole kingdom to the left. The palacography of the annals in this manuscript, like $\mathbf{M}$ and $\mathbf{F}$, shows very clearly that many people were involved in the process of writing and recording history in different centres across Carolingian Francia. The manuscripts show how 'history' could be written by many different hands contributing to the marginalia of a single copy of a text; this is a commonplace of annalistic texts since the anonymity of the entries opens up the annal-series to scribal additions, emendations and changes, in a way that a text by a named author does not. This contrast is very obvious in these manuscripts where the core texts - the Cyclus paschalis or the DTR that follows - are copied with great care and precision; but many hands contribute to the marginalia. ${ }^{70}$

\section{Anglo-Saxon England}

The Anglo-Saxon annals have two major themes; firstly, the succession of the seventh-century kings of Kent where the entries are essentially an obit list and, secondly, Northumbrian history of the later seventh century focusing on the dates of the accession of the kings of Northumbria and the obits of the bishops of Lindisfarne. The death of Archbishop Theodore of Canterbury is also recorded s.a. 690, with the date of his death given precisely to the day of the week; he died on Monday 19 September 690 . We have already noted that none of our manuscripts contains all of the annals on both Kentish and Northumbrian affairs. This observation has implications for our understanding of the transmission of the annals since we must assume that none of the surviving manuscripts was the exemplar for all of the others.

It is theoretically possible that the very fragmentary Northumbrian manuscript, $\mathbf{M}$, did once contain both Kentish and Northumbrian annals and that all bar the extant Northumbrian entries for 658,664 and 670 were written onto the folios that are now lost; but had that been the case we might reasonably

70 The text of the DTR is remarkably stable across the 245 surviving manuscripts, despite its technical language; Jones, Bedae Opera de Temporibus, pp. 140-1. 


\section{The Frankish Annals of Lindisfarne and Kent}

rical notes

inastery; it is process,

St Amand $y$ of that ipt shows ne scribe; of local he whole icript, like le process arolingian by many text; this ies opens in a way $s$ in these at follows ute to the

on of the it list and, ig on the ts of the terbury is he day of oted that atish and rstanding f the sur-

in manuid that all tten onto asonably despite its

have expected to see the Kentish material in the two Fulda manuscripts which derive their Anglo-Saxon material from $\mathbf{M}$. That neither $\mathbf{F}$ nor $\mathbf{K}$ includes the Kentish material encourages us to conclude that it was not in their exemplar, M. It is possible that the Fuldan scribes may have omitted the Kentish material deliberately as irrelevant to their purpose, but this is improbable since both these manuscripts also contain an eclectic mix of annals incorporating references to the abbey of Fulda and wider Carolingian history, as well as the chronology of Roman and Byzantine emperors. It is far more likely that our Earliest manuscript, $M$, which seems to have been written in Northumbria, contained only the annals relating to that kingdom. This implies that another manuscript(s), now lost, carried the Kentish data to Francia where it was conflated with the Northumbrian annals, or that the conflation of the two sets happened somewhere in England to be carried abroad at a date before 800 when the earliest of our manuscripts containing both Kentish and Northumbrian material was written at St Amand (W).

That the Anglo-Saxon annals were originally two distinct sets - one concerning Kent, the other Northumbria - is rendered more likely when we examine the form of the information preserved from each kingdom. The chief characteristic of the Kentish data is the detailed dates provided for each event recorded; all are recorded by year, month, day of the month, and day of the week. This is not the case for the Northumbrian information where the chronological content of the annal is simpler; only the year of each event is recorded and a precise date is given only in the annal recording the solar eclipse in 664. Also, the Kentish annals are exclusively obits, whereas the Northumbrian ones refer to the beginning of kings' reigns, to the obits of bishops and, in 664, to a solar eclipse. These variations in form and content suggest that the annals were recorded originally under two separate traditions in two separate places.

\section{Kent and Canterbury}

The most striking feature of the Kentish annals is the habitual use of the Roman calendar to record dates that (in all bar two cases) are accurate to the day of the week. ${ }^{71}$ Thus, for example, Ethelberht died, according to these annals, on the 6th kalends of March on the fourth day of the week. Bede provided this date in the $H E$ not in the retrograde fashion of the Roman kalends, but directly, projected forwards into the month (as we do in our modern style of dating) so that he says $Æ$ thelberht died on the '24th day of the month of

71 Levison recognized the importance of these annals but noted 'a few mistakes in ycars and days'; Levison, England and the Continent, p. 274, at n. 2. When all the manuscripts are consulted there are only two demonstrable errors in the core text: the year of Wthelberht's death is indistinct, and the day of the week given for the burial of Eadbald is a day late.

81 


\section{Joanna Story}

February' in $616 .{ }^{72}$ In fact, in doing this Bede may have made a slight error, because 616 was a leap jear and 6th kalends of March was, in fact 25 February not 24 February, and in 616, 25 February was a Wednesday as our annals state. ${ }^{73}$ This implies that either Bede or his source for this entry had an accurate record of the date of Æthelberht's death in the style of the Roman calendar, but when the date was turned from the retrograde Roman form to the direct style it was 'forgotten that $\approx$ thelberht's death had occurred in a leap year, thereby causing a dislocation of the date by a single day in $H E$ II.5. This would suggest that Bed 's immediate source here was not an annal sitting alongside an Easter table where the leap years are marked out prominently by the capital letter, B (for bissextilis).

We should note, however, that although the day of the month and day of the week of Athelberht's death is given correctly in our annals, the year of his death is obscure, since the entry is copied over several lines in the two manuscripts in which the note is found; in W it is written alongside the years 620-22 and in P1 the entry brackets an even longer period, 617-24. This is a good illustration of the ease with which the record of an event could slip a year or two when written alongside an Easter table. But even Bede's account of Ethelberht's death in the $H E$ contains inconsistencies: at the beginning of $H E$ II.5, Bede says that IEthelberht died in 'the twenty-first year after Augustine and his companions had been sent to preach to the English nation' ( 595 plus $21=616$ ), whereas later in the chapter he says that Æthelberht's death occurred 'twenty-one years after he had accepted the faith' $(597$ plus $21=618) .^{74}$

The Kentish annals also record the dates on which the next five kings of Kent were buried. The verb used in every case is depositus rather than defunctus or obiit. This distinction may be real since, for the two of the five kings, Bede also provides a precise date of death which is a day earlier than the date of

$72 H E$ II.5. On the transition from the retrograde Roman dating system to cumulative, direct dating (with epigraphic evidence dating from the fourth century), sec M. Handley, Death, Society and Culture: Inscriptions and Epitaphs in Gaul and Spain, $A D$ 300-700, BAR Int. ser. 1135 (Oxford, 2003), 118-21 and figs. 7.5 and 7.6.

73 In order to count the extra day in February in a leap year, 24 February is bis .ti. Kal. Mar. and 25 February is .ti. Kal. Mar., C. R. Cheney, A Handbook of Dates for Students of British History, 2nd cd., rev. M. Jones, R. Hist. Soc. Guides and Handbooks 4 (Cambridge, 2000), 7, 145-6 and 196. On Bede's dates for the seventh-century kings of Kent, see also Cbarters of $S t$ Argustime's, ed. Kelly, $\Lambda$ ppendix 3, pp. 195-203.

$74 H E$ I.25-6 and II.5; DTR c. 66, Bedae Opera de Temporibus, ed. Jones, p. 523; Wallis, Reckoning of Time, p. 226. See also, C. Plummer, Venerabilis Baedae Opera Historica, 2 vols. (Oxford, 1896) II, 85; Harrison, Frameuork, p. 79; D. P. Kirby; 'Bede and Northumbrian Chronology', EHR 78 (1963), 514-27, at 521; J. M. Wallace-Hadrill, Bede's Ecclesiastical History of the English People: a Historical Commentary' (Oxford, 1988), p. 57; R. Gameson, 'Context and Achievement', St Augustine, ed. Gameson, pp. $1-40$, at 21-2. This inconsistency has led some to date AEthelberht's death 616 x 618 . 


\section{The Frankish Annals of Lindisfarne and Kent}

light error, 5 February nals state. ${ }^{73}$ rate record ; but when style it was by causing lggest that iaster table , B (for bis-

day of the $f$ his death uscripts in and in P1 stration of en written eath in the says that impanions iereas later years after

e kings of n defunctus ings, Bede 1e date of

lative, direct adley; Death, nt. ser. 1135

al. Mar. and itish History, 0), 7, 145-6 Darters of $S t$

Reckoning of rd, 1896) II, y', EHR 78 lish People: a wement', $s t$ ne to date

burial given in the annals. Thus, Bede tells us that Earconberht died (defunttus) in 664 on pridie idumm Inliarum (14 July) whereas our annals say that he was depositus idus Iulii feria .ii. (Monday $15 \mathrm{July}) .^{75}$ Similarly, when Bede tells us that in 685 Earconberht's son Hlothhere mortums erat .riii. idus Februarias (6 February) our annals give the following day as the date of his burial, .izii. idus Februarias feria .iii. (Tuesday 7 February). ${ }^{76}$ On both occasions the annals supply the day of the week that is correct for the year cited, thus encouraging confidence in their accuracy.

i Bede does not, however, provide precise dates for the deaths of Eadbald, Ecgberht and Eadric, the other three kings of Kent that are found in our annals, just the year or the year and month of their deaths. For these three kings, therefore, the dates provided by our Kentish annals are unique, and cannot be found elsewhere in the corpus of Anglo-Saxon historical texts. Thus, our annals tell us that Eadbald was buried in 640 on .xiii. kalendas Februarias feria .ti. (Friday 20th January) whereas Bede provides just the year of his death (pl. II). ${ }^{77}$ Ecgberht was buried in 673, according to the annals, on .iiii. nonas Iulii feria .ii. (Monday 4 July) whereas Bede notes only that he had died that year in July (pl. III) ${ }^{78}$ Lastly, Bede tells us that Eadric reigned for 'a year and a half' after the death of Hlothhere in February 685; our annals provide the precise date for Eadric's burial in 686, .ii. kalendas Septembris feria .vi. (Friday 31 August) (pl. IV). ${ }^{79}$

This interest in the dates of burial of the kings may reveal something about the concerns of those recording these events and where these records were kept. It may also suggest that the information noted in the annals was recorded originally in an alternative format, perhaps within a liturgical calendar or necrology, or as epitaphs. For those doing the recording, the dates of burial may have been more immediately knowable than the dates of death, particularly if the record keepers had been based in the place where the kings of Kent were customarily buried. In the seventh century that place was the monastery of SS Peter and Paul at Canterbury.

75 HE IV.1. This annal is only found in P2. ${ }^{76}$ HE IV.26.

77 HE III.8, V.24. In 640, 20 January was in fact a Thursday (it was a leap jear); Cheney, Handbook, p. 206.

${ }_{78}$ HE IV.5, V.24. On the re-dating of the Synod of Hertford to 672, sce Levison, England and the Continent, pp. 266-7. Manuscript P1 preserves the correct day of the week, Monday; P2 gives feria iii, ie: Tuesday:

i9 $H E$ IV.26. See also, Handbook, ed. Fryde, p. 13 where the date 687 is given for these annals. This must be derived from our manuscript $\mathbf{P 1}$ rather than $\mathbf{P 2}$ which provides the earlier, correct year 686; the day of the week given in P1 and P2 is correct for 686. Note how in both manuscripts the annal takes up more space than allotted for one year. Note also in P1 the addition of an annal recording the accession of Pippin I (as mayor of the palace in Austrasia) in 688/89 and, in both copies, the annal for the accession and length of rule of the Emperor Marcus Antoninus Verus (i.e. Marcus Aurelius) s.a. 695 (recte $\mathrm{AD}$ 163) from the first Great Cycle. 


\section{Joanna Story}

These observations demonstrate that the Kentish annals cannot have been derived from the Historia ecclesiastica nor indeed from any of Bede's other writings, and thus they stand independent from the corpus of his work. But clearly, Bede's Canterbury informants - Abbot Albinus and Nothhelm the priest - had provided him with a source that was essentially similar to our Kentish annals, and from that he obtained precise dates for the deaths of Kings $Æ$ thelberht, 'Earconberht and Hlothhere. He may have chosen, for some reason unknown to us now, to omit the full dates of the deaths of the other seventh-century kingl of Kent but, given his obsession with chronology and his habit of interweaving and cross-referencing different dating systems, this is unlikely; if he had had full dates for the death or burial of Eadbald, Ecgberht and Eadric, he would have used them. Thus, these annals prove what we have otherwise assumed from the material embedded in Bede's writing - but which is hard to prove outside the corpus of law codes and later seventh-century charters - that accurate chronological records were calculated and kept in Kent from at least 640 when the precise date of Eadbald's burial was carefully recorded. ${ }^{80}$

\section{Easter tables in seventh-century England}

This is important since these annals have been used to support the case for the existence of Dionysiac Easter tables in England 'throughout the seventh century' long before Bede's own 'scientific' writing popularized the use of the Dionysiac Cychus pascbalis (and with it the habit of writing marginal annals). ${ }^{81}$ Jones followed earlier scholars in believing that our annals had been composed in the margins of Easter tables, and that Bede had received them and others like them either in that form or as free-standing texts derived from paschal annals of this type. Furthermore, he and others have argued that this type of material is reflected in the chronological recapitulation in $H E$ V. $24 .{ }^{82}$ Bede's use of Dionysiac Easter tables to collate Anno Domini dates with those of the Indiction in the $H E$ is not in doubt (these figures are given in parallel in the first and second columns of the tables), ${ }^{83}$ but it is much less clear that

${ }^{80}$ Charters from Minster-in-Thanet use precise calendar dates, whereas those from St Augustine's have simpler dating clauses. Amno Domini dates are an eighth-century development; Charters of St Augustiue's, ed. Kelly; pp. lxxxiii-lxxxiv: See also, Handley; Deatb, Society and Calture, p. 21.

81 Jones, Bedae Opera de Temporibus, pp. 119-21. Levison is more circumspect, and argues that such tables and accompanying annals were circulating from the early eighth century, Levison, England and the Continent, p. 270, and n. 3. But sce Wattenbach and Levison, Dentscblands Gescbicbtsquellen, p. 52. On the importance of Bede's work for the promotion of the Dionysiac over the Victorian version of the Alexandrian calculation, see Wallis, Reckoning of Time, pp. 1xii-lxiii.

82 For Bede's citation of two solar eclipses in 538 and 540 derived from an Italian annalistic source, and his use of material in $H E$ V.24 that is not in the main body of the text, sec Levison, 'Bede as Historian', pp. 135-7. ${ }^{83}$ See, for example, HE III.18.

84 


\section{The Frankish Annals of Lindisfarne and Kent}

have been other writBut clearly, riest - had ish annals, :thelberht, unknown th-century it of interkely; if he Eadric, he othervise is hard to ters - that im at least 1.80

ise for the e seventh ase of the annals). ${ }^{81}$ composed nd others $n$ paschal is type of ${ }^{82}$ Bede's sse of the llel in the clear that

e from St ry developb, Society and argues that ry, Levison, Destsschlands a Dionysiac of Time, pp. n annalistic ae text, see
Dionysiac Easter tables had been used for the yearly record of events in England very long before Bede's day. Our annals apparently' provide the main evidence that they had. ${ }^{84}$ Much depends, however, on whether our Kentish data are true annals (as Jones and others believed) that were noted down contemporaneously alongside Easter tables, or whether they were historical notes, derived retrospectively from different types of sources (such as epitaphs, cal-

- endars or necrologies) and copied from there into an Easter table long after the events they describe.

IEaster tables were certainly used for recording historical events by Bede's day; the earliest surviving manuscript of the tables devised by Victorius of Aquitaine in the mid fifth century, Gotha, Landesbibliothek, Mbr. I.75, fols. $70-122$ (Jouarre?, s. viii ${ }^{1}$ ), has a note in its margins concerning an cvent that took place in the year 501. But this note may have been interpolated from a copy of the Historiae of Gregory of Tours that was at Jouarre when the manuscript was copied in the earlier eighth century, rather than being transferred from the exemplar of its Victorian Easter tables. ${ }^{85}$ Harrison also argued, on the basis of probability rather than proof, that the Frankish priest Liudhard was likely to have been in possession of a set of Victorian Easter tables when working in Kent as chaplain to Ethelberht's queen, Bertha, before Augustine's arrival in 597, and that such a table could have provided the impetus and a chronological framework for the translation of oral memories concerning the succession of the earliest kings of Kent into written form. ${ }^{86}$ Similarly, O Croinin has argued that annals were noted alongside the tables of the eightyfour-year cycle in Ircland by the mid-seventh century, and perhaps as early as the mid-sixth century. ${ }^{87}$ Others have argued that the discordant chronology of

84 Harrison, Framenork, p. 46; Levison, England and the Continent, p. 267; Jones, Bedae Opera de Temporibus, p. 121 , at n. 5 . For the suggestion that an annalistic chronicle was being kept in Northumbria, perhaps at Jarrow; and perhaps alongside an Easter Table, from 685, see P. H. Blair, 'The Northumbrians and their Southern Frontier', $A A$ e, 4 th ser. 26 (1948), 98-126, at 105-12.

85 Lowe, CLA VIII.1208. Jones, Bedae Opera De Temporibus, pp. 99, 103-4 and 119; D. Ó Cróinín, 'Early Irish Annals from Easter-Tables: a Case Restated', Peritia 2 (1983), 74-86 at 77 . On the origin and date of the manuscript see R. Mchitterick, 'Nuns' Scriptoria in England and Francia in the Eighth Century', Francia 19.i (1992), 1-35 at 5, reprinted as chapter VII in her Books, Scribes and Learning in the Frankish Kingdons, 6tb-9tb centuries (Aldershot, 1994), and McKitterick, History and Memory, p. 98.

86 Harrison, Framenork, pp. 123-4, citing D. P. Kirb;; 'Vortigern', BBCS 23 (1968), 37-59, esp. 44-8. Victorius's second Great Cycle began in $A D 560$ ( $A \mathrm{P} 532$ ).

87 Ó Cróinin, 'Early Irish Annals from Easter-Tables', pp. 77-8 and 80-3. See also, D. McCarthy and Ó D. Cróinín, "The "Lost" Irish 84-year Easter Table Rediscovered', Peritia 6-7 (1987-8), 227-42. McKitterick questions $O$ Cróinin's assumption that extant Easter tables acquired their marginal annal entries from their exemplars rather than being copied retrospectively from another source (all his examples survive in other forms); Mickitterick, History and Memory' pp. 97-8. 


\section{Joamna Story}

the late fifth- and early sixth-century West Saxon annals in the Anglo-Saxon Chronicle derives from the slippage of data from one nineteen-year Dionysiac Easter table to the next. No-one, however, has suggested that this copying error could have happened before the mid-seventh century at the earliest, implying that the West Saxon annals were applied retrospectively to an Easter Table from another type of record (written or oral)..$^{88}$ This dislocation of the - early West Saxon data could only have happened after the point at which it was realized that the Dionysian system could be expanded to a Great Cycle of 532 yeark, and that the Great Cycle could be projected backwards in time (as well as forwards) to cover the first 531 years of the Christian Era. Bede was the first to publish a Dionysian Great Cycle, though - Wallis argues - it it possible that such a Great Cycle was in circulation before the DTR was composed. ${ }^{89}$

The Irish eighty-four-year cycle used no era to anchor its calculations and Victorius's cycle was dated according to the annus Passionis (alongside a list of consuls as far as 457), rather than the anmus Domini that was used in Dionysius's system. The difference in era between the Victorian and Dionysiac systems was of secondary importance to those who used the tables to discover the date of Easter in future years, since contemporary temporal orientation was usually sought by a combination of the indiction and regnal years. ${ }^{90}$ But the difference in era used by the two systems was crucial to anyone using an Easter table to record 'historical' events, since an annal recorded alongside a Victorian table using the era of the Passion would appear to have occurred twenty-seven years

88 The mid-seventh century date supposed for the miscopying of the annals is based on two assumptions: that it cannot have happened until after the conversion of the West Saxons to Christianity and that the conversion quickly stimulated the production of written historical records; F. M. Stenton 'The Foundations of English History', TRHS, 4th ser. 9 (1926), 159-69, repr. in his Preparatory to Anglo-Saxion England (Oxford, 1970), pp. 116-26, csp. 119-21; K. Harrison, 'Early Wessex Annals in the Anglo-Saxon Chronicle', EHR 86 (1971), 527-33, esp. 530; idem, Framenork, pp. 127-34; D. N. Dumville, 'The W'est Saxon Genealogical Regnal List and the Chronology of Early Wessex', Peritia 4 (1985), 21-66, esp. 44-5, repr. in his Britons and Anglo-Saxons in the Early diddle Ages (Aldershot, 1993), ch. 8.

${ }^{89}$ Unless, that is, the calculations were made against a set of Victorian nineteen-year cycles, and the absolute dates later transposed from Ano Passionis to Amno Domini. Victorius's table extended 532 years, beginning in the year of the Passion, according to his calculation of the date of that event (that is by our reckoning, $\lambda D$ 28-559). Dionysius's tables were calculated initially for $5 \times 19$ years, that is $532-626$, and extended by ' $F$ clix' for a further ninety-five, from 627-721; Wallis, Reckoning of Time, pp. 155-6 and 352-3, and below; n. 92. On the possible use of Victorian Easter tables in the preservation of the early West Saxon regnal chronology; see P. Sims-Williams, 'The Settlement in Bede and the Cbronitle', ASE 12 (1983), 1-41, esp. 35-6.

${ }^{90}$ See the carliest Kentish charters from the reign of Hlothhere, $\mathrm{S} 7$ (dated 1 April 675, Cbarters of St. Augustine's, ed. Kelly, no. 6) and S 8 (dated 679, reproduced in Lowe, English Uncial, pl. xxi). In references to Anglo-Saxon charters, $\mathrm{S}=\mathrm{P}$. H. Sawyer, Anglo-Saxion Charters: an Amotated List and Bibliograply, R. Hist. Soc. Guides and Handbooks 8 (London, 1968), followed by the number of the document. 
iglo-Saxon Dionysiac is copying ac earliest, , an Easter ion of the hich it was cle of 532 ne (as well as the first sssible that $\mathrm{d}^{89}$

ations and te a list of Jionysius's 'stems was he date of ras usually' difference er table to srian table even years

ased on two st Saxons to en historical :r. 9 (1926), esp. 119-21; 71), 527-33, gical Regnal repr. in his

r cycles, and orius's table ation of the re calculated ty-five, from possible use onology, sce 1 , esp. 35-6. 575, Charters sh Uncial, pl. Charters: an , 1968), fol-

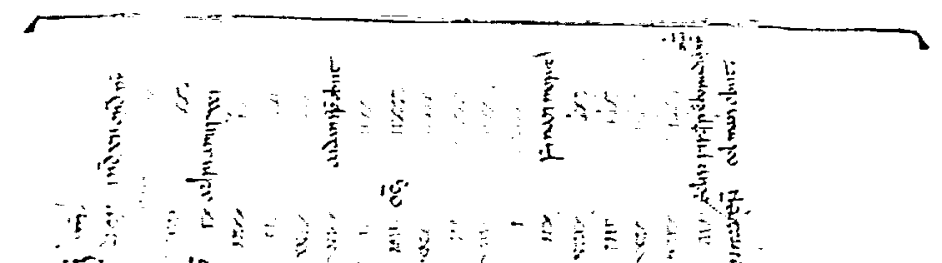

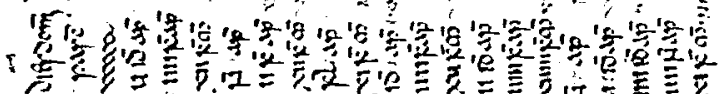

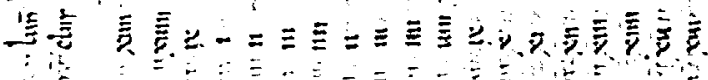

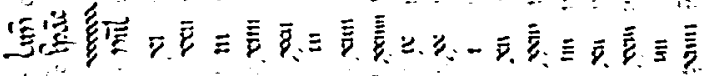

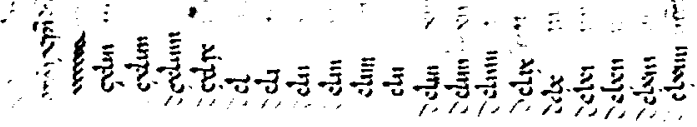
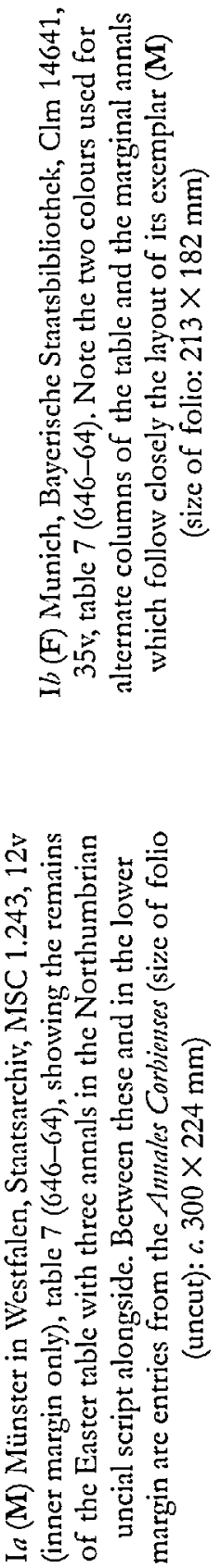
iglo-Saxon Dionysiac is copying re carliest, an Easter ion of the hich it was cle of 532 ae (as well as the First ssible that d. 89

ations and le a list of jionysius's stems wats he date of ras usually difference or table to rian table even years

ased on two st Saxons to en historical :r. 9 (1926), esp. 119-21; 71), 527-33, vical Regnal repr. in his

r crdes, and orius's table ation of the e calculated $y$-tive, from possible use jology, ste 1, esp. 35-6. 375, Cbarters ih Lacial, pl. Charters: an , 1968 , 5ol-

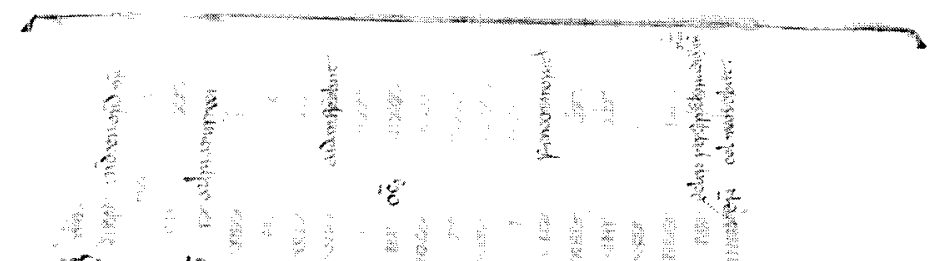

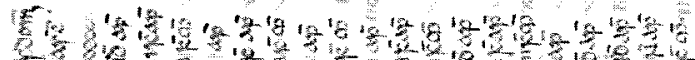

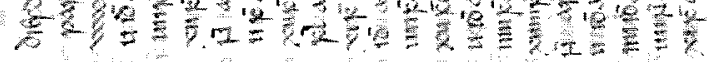

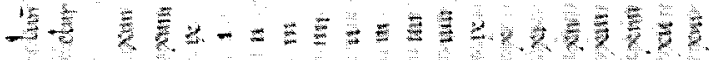

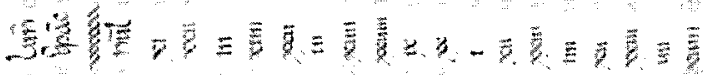

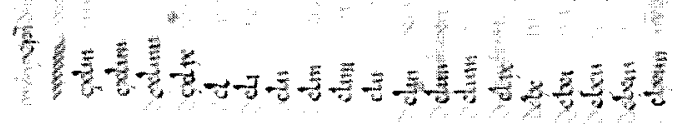

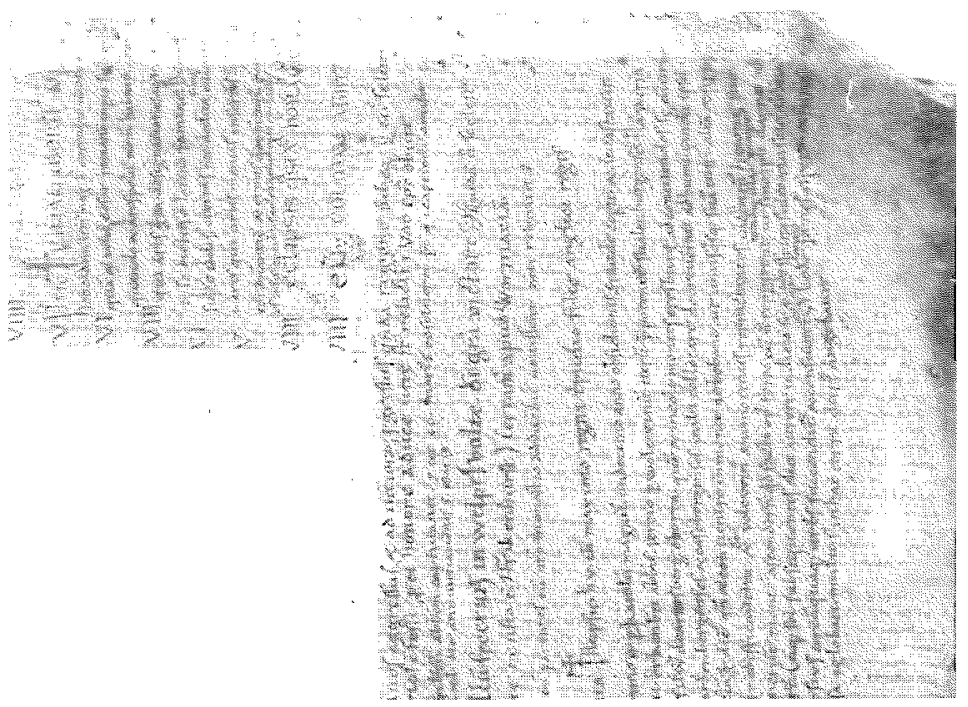

ब $\frac{E}{E}$ 焉

व

$\because \mathscr{E}$

$\bigcup_{2}=0.5$

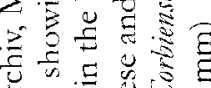

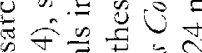

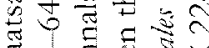

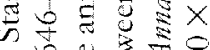

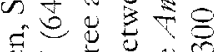

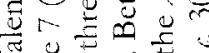

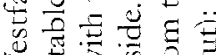

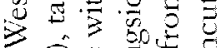
$\Xi$ E

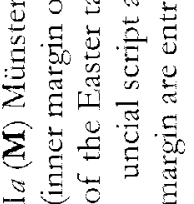




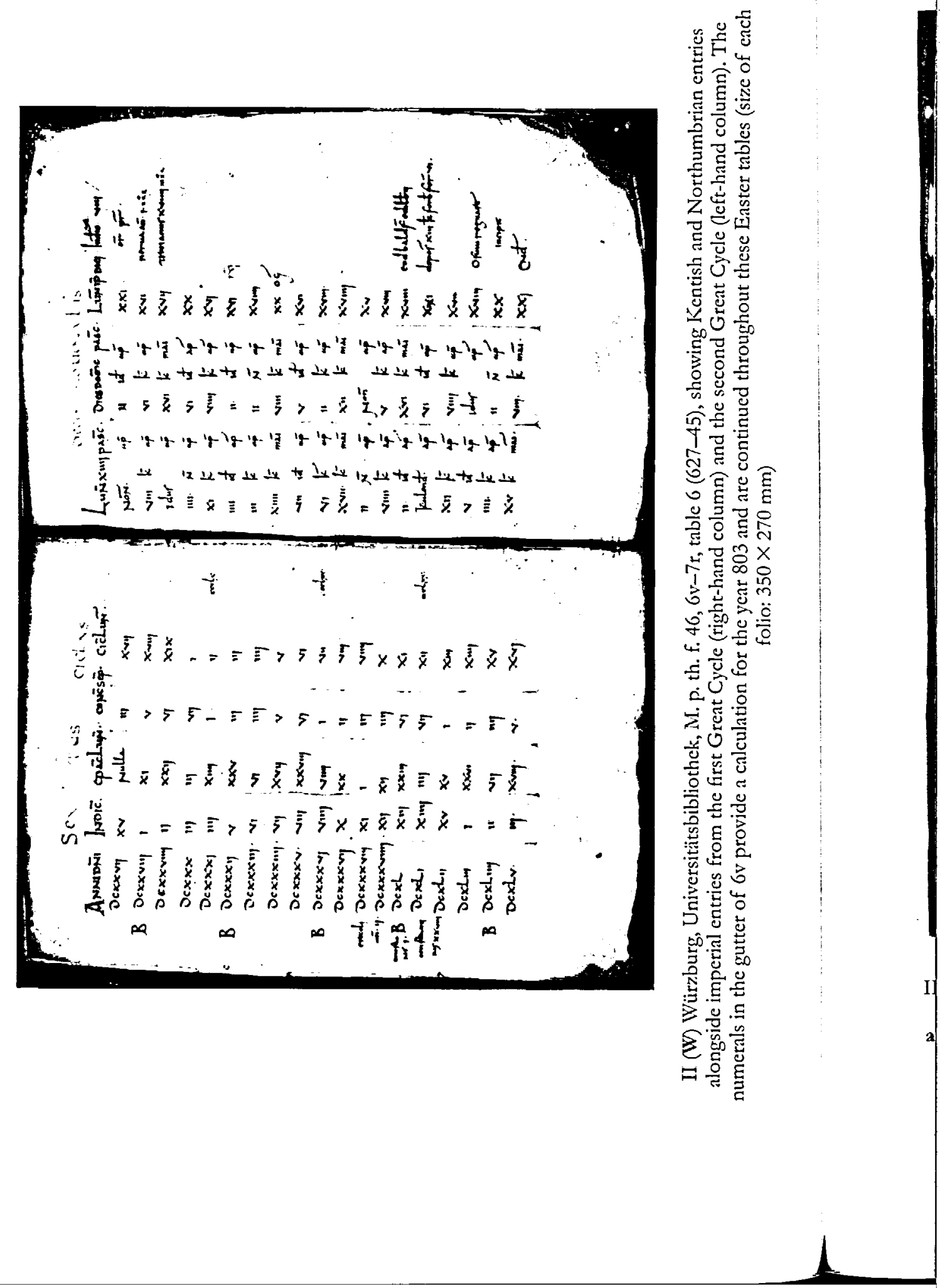




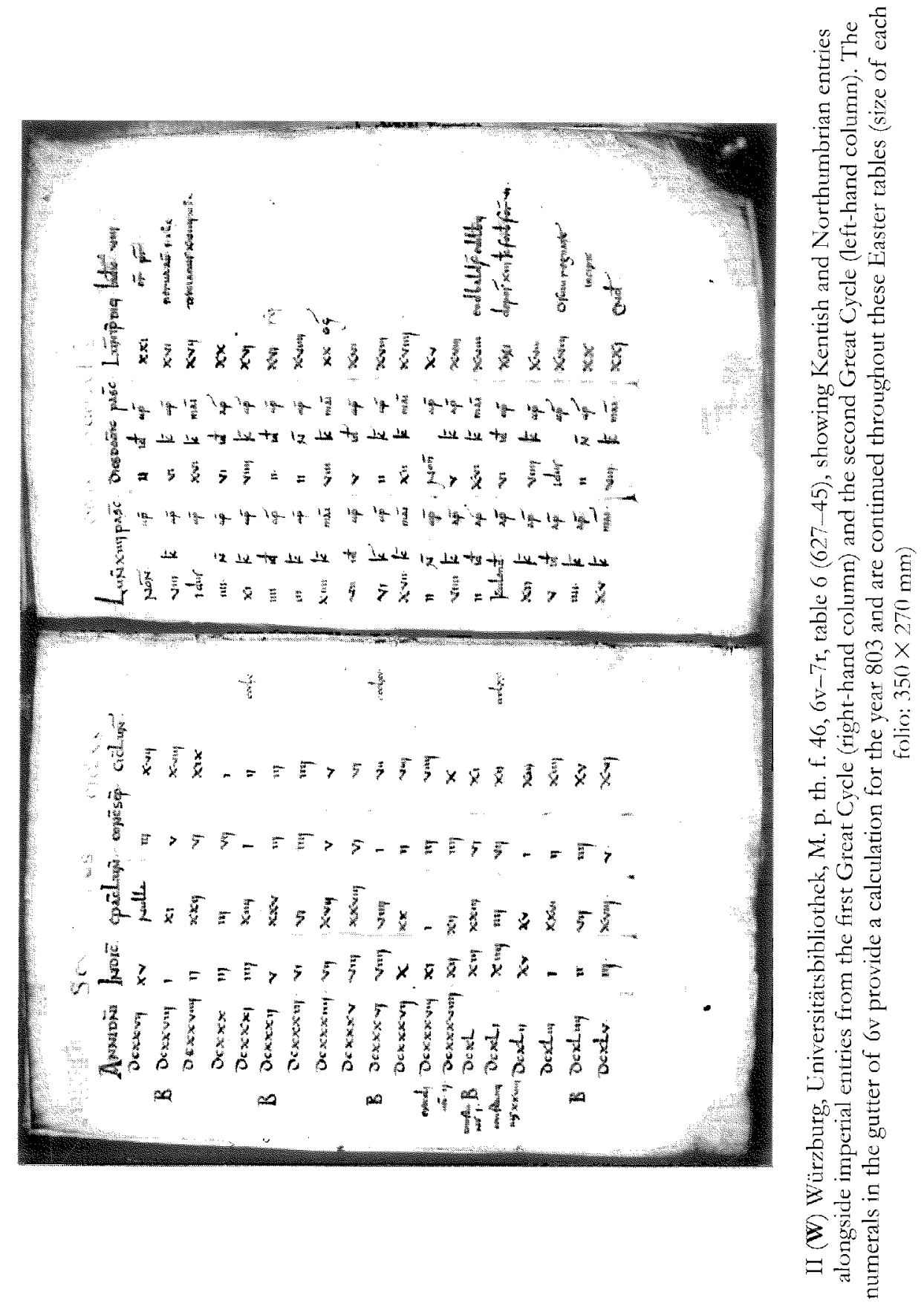




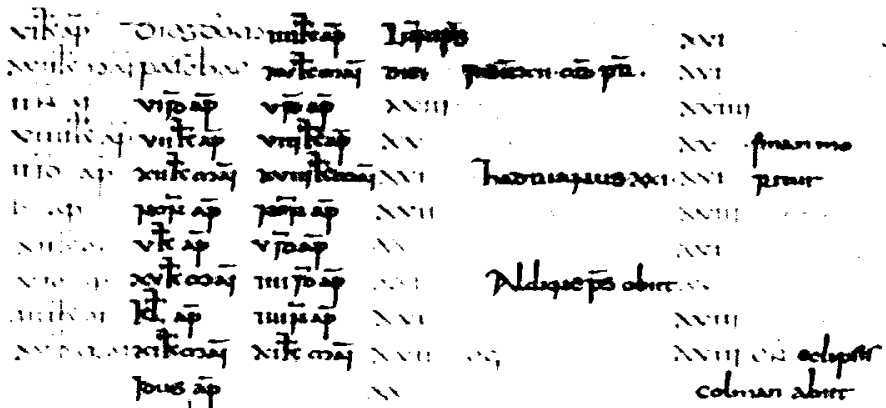

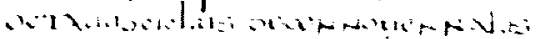

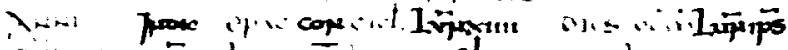

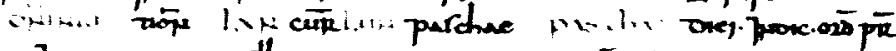

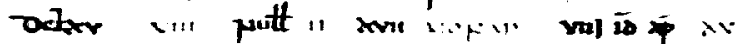

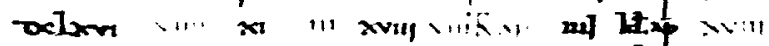

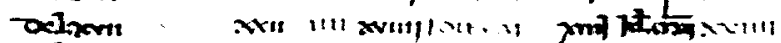

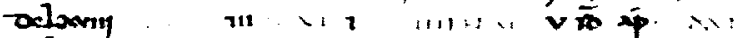

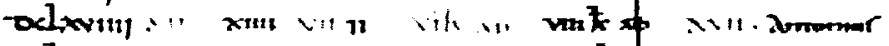

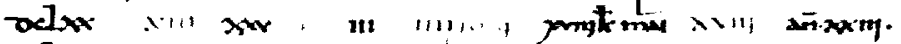

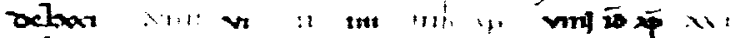

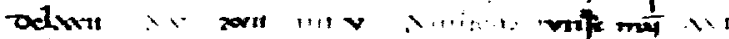

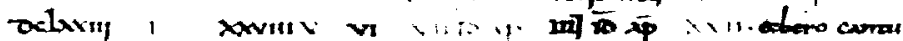

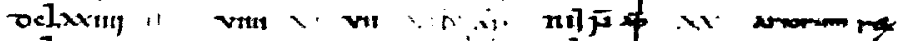

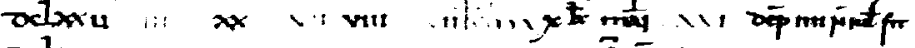

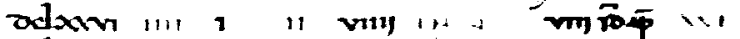

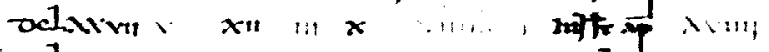

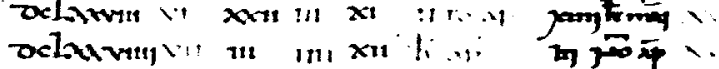

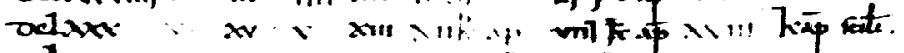

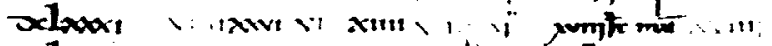

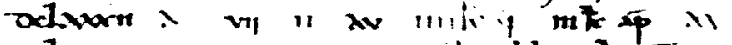

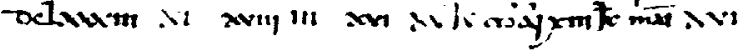

III (P1) Paris, Bibliothèque nationale de France, lat. 13013, 11 , table 8 (665-83), with part of table 7 above, showing a combination of imperial, Kentish, Northumbrian and Frankish entries (the latter by a second, later hand) (size of folio: $287 \times 227 \mathrm{~mm}$ ) 
III (P1) Paris, Bibliothèque nationale de Irance, lat. 13013, 11v, table 8 (665-83), with part of table 7 above, showing a combination of imperial, Kentish, Northumbrian and Frankish entries (the latier by a second, later hand) (size of folio: $287 \times 227 \mathrm{~mm}$ ) 


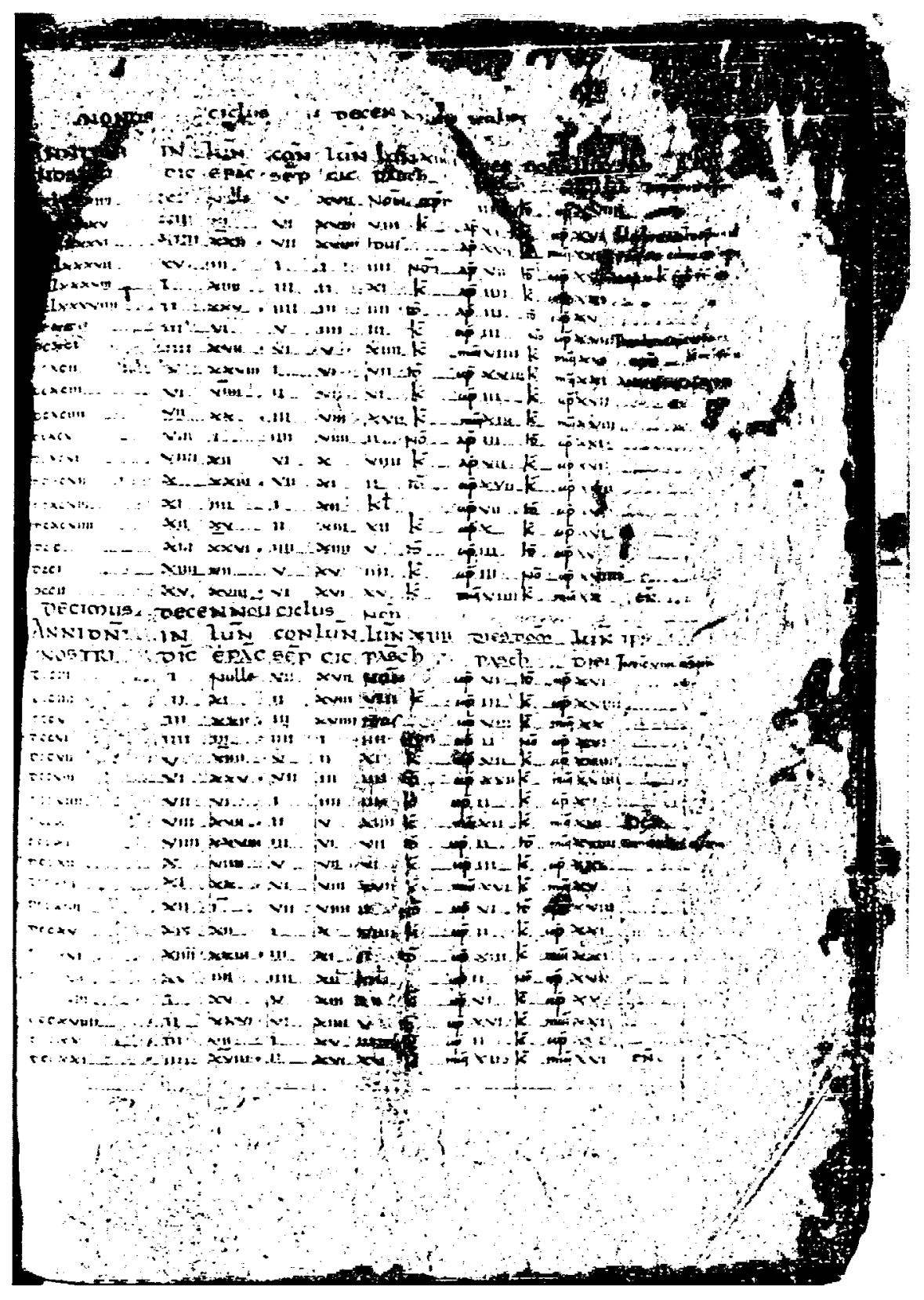

IV (P2) Paris, Bibliothèque nationale de France, nouv: acq. lat. 1615, 14r, table 9 (684-702) and table 10 (703-21), showing a combination of imperial and Kentish entries (size of folio: $320 \times 237 \mathrm{~mm}$ ) 


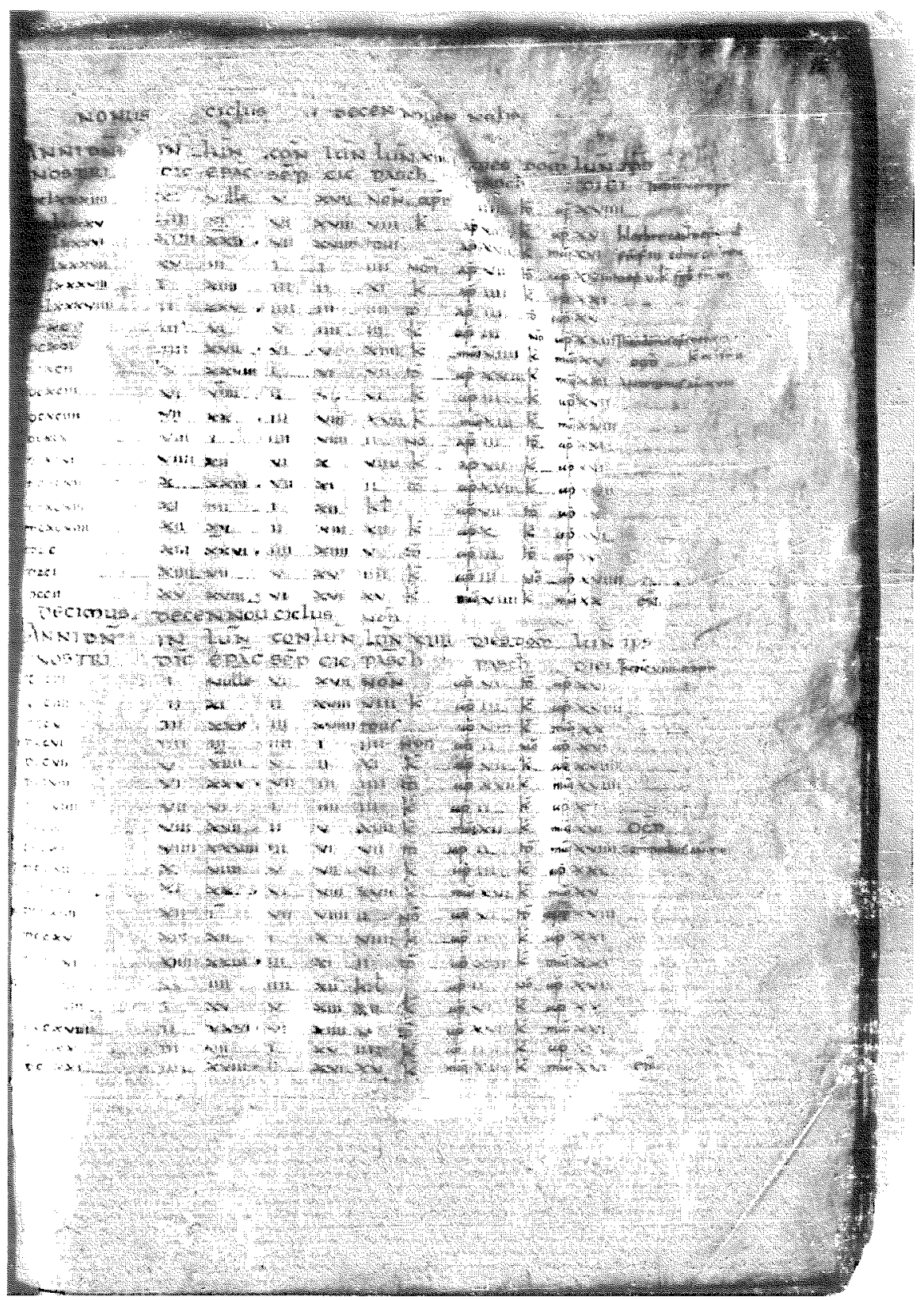

IV (P2) Paris, Bibliothèque nationale de France, nouv. acc. lat. $1615,14 \mathrm{r}$, table 9 (684-702) and table 10 (703-21), showing a combination of imperial and Kentish entries (size of folio: $320 \times 237 \mathrm{~mm}$ )

earliet era of Incarn Fastert that st signifie But centut svstem systen in wes fact th be pre John I they $x$ duced from Irelank defeno to aldo the $S$. was at which systert culatio have eative

9 poo matt Wall drave Cról

$92 \mathrm{On}$ is p. live 


\section{The Frankish Amnals of Lindisfarne and Kent}

earlier than if it had been recorded alongside a Dionysiac table which used the era of the Incarnation. Our Kentish annals, recorded by the era of the Incarnation, have been used to argue both for the existence of Dionysiac Easter tables in Kent in the first half of the seventh century and as evidence that such tables were used at the time for recording events of historical significance.

But the evidence for the presence of Dionysiac tables in early-seventhcentury England is not straightforward; nor is it certain exactly when that system came to be preferred in Canterbury over and above the alternative system provided by the tables of Victorius of Aquitaine that was used widely in western Europe, especially in Gaul. This problem is complicated by the fact that we cannot be sure exactly when Dionysius Exiguus's system came to be preferred in Rome itself. ${ }^{91}$ His revised calculations were presented to Pope John I in 525, and were known later to Cassiodorus and to Isidore of Seville; they were circulating in North Africa c. 616, when 'Felix of Ghyllitanus' produced a continuation of the first table, extending it a further ninety-five years from $627-721 .^{92}$ The Dionysiac calculation was also known in southern Ireland in 632-3 when Cummian wrote his Epistola de controversia pascbali in defence of the 'Alexandrian reckoning', which the southern Irish had decided to adopt as a consequence of a letter from Pope Honorius and the debate at the Synod of Mag Léne. ${ }^{93}$ Furthermore, Bede's major source for the DTR was an Irish computistical collection, compiled in southern Ireland in 658, which included the Dionysiac tables and argumenta as well as the Victorian system. ${ }^{94}$ However, despite fundamental differences in the principles of calculation between Dionysius's system and that of Victorius, there seems to have been little distinction made between these two sets of tables in the earlier seventh century probably because, in practice for this period, they

91 Poole, Studies in Cbronology and History (Oxford, 1934), pp. 28-37. The debate (to 1976) is summarized by Harrison, Framenork, pp. 55-62. Readers are referred to the lucid exposition in Wallis, Reckoning of Time, pp. xxxiv-lxiii, especially liii-lv, on which the following section draws. Commian's Letter 'De Controtersia Pasclbali' and the 'De Ratione Computandi, cd. D. Ó Cróinin and M. Walsh, Stud. and Texts 86 (Toronto, 1988), 38.

92 On the continuation and the identification of its author as Felix of Ghyllitanus, Poole, Studies in Cbronology and History', p. 23; Levison, 'Bede as Historian', p. 118; Wallis, Reckoning of Time, p. liv, but see Jones, Bedae Opera De Tentporibus, pp. 73-4.

93 The system adopted and defended by Cummiàn seems to have used the Victorian and Dionysiac tables interchangeably; Wallis, Reckoning of Time, pp. lix-lxii; Ó Cróinin and Walsh, Cummian's Letter, Introduction, Scction $\Lambda$ and p. 46.

${ }^{94}$ This collection is best represented by the so-called 'Sirmond' manuscript, now Oxford, Bodleian Library, Bodley 309 (s. xi; provenance Vendòme); C. W. Jones, "The "Lost" Sirmond Manuscript of Bede's Computus', EHR 51 (1937), 204-19; idem, Bedae Opera De Temporibus, pp. 105-10; D. Ó Cróinín, 'The Irish Provenance of Bede's Computus', Peritia 2 (1983), 229-47; Wallis, Reckoning of Time, pp. Ixxii-lxxix. 
produced the same result for the date of Easter; the point of contention in the earlier seventh century was thus the divergence between the 'Celtic-84' and the 'Alexandrian' system represented by both the tables of Victorius and those of Dionysius. ${ }^{95}$

In its dealings with clergy from the British Isles before c. 640 the papacy seems to have been concerned to enforce a generic Alexandrian system over and above the offensive eighty-four-year Celtic table. ${ }^{96}$ Bede tells us that Pope Honqrius had written to the Irish, c. 628/9, instructing them to conform to the 'correct' reckoning, and that in 640 , Pope-elect John IV had written again with arguments 'of great authority', this time to the clergy of the northern Irish who still refused to conform. ${ }^{97}$ It seems that by the date of John's letter, Rome had come to understand that the problems with the Victorian tables were insurmountable since they produced an unacceptable date for Easter 641, apparently reckoning it to be on the fourteenth day of the lunar month which lay outside the permissible parameters for the date of Easter according to Dionysius's argumenta. ${ }^{98}$ John's letter thus accused the Irish of reverting to the Quartodeciman heresy (an exaggerated charge that Bede knew to be wrong and chose to overlook); in doing so, John's letter suggests that he was aware of the problem caused by the Victorian calculation for 641 and that the virtues of the Dionysiac reckoning were understood and preferred in Rome. ${ }^{99}$

It was certainly the Dionysiac reckoning that Wilfrid learned from Archdeacon Boniface in Rome in 654. Dissatisfied with the system he had learned in Lindisfarne, he had travelled from Northumbria, via Canterbury, to Rome where he learned, among other things quae in patria nequiuerat, 'the correct method of calculating Easter'. ${ }^{100}$ Wilfrid's journey has been interpreted as evidence for the absence of Dionysiac Easter tables in Northumbria or Kent in the early 650s, and thus that Wilfrid was responsible for introducing them on his return, along with the notion of calculating Christian time by the era of Christ's

95 Cheney, Handbook of Dates, pp. 147-54.

${ }^{6}$ For example, Columbanus's letter to Gregory the Great complaining that Frankish bishops were trying to enforce the Victorian reckoning on his monks; Wallis, Reckoning of Time, pp. Iv-lvi. ${ }^{97}$ HE II.19; DTR ch. 66 (AM 4591); Wallis, Reckoning of Time, p. 228.

98 The inscrtion by Victorius of the saltus lomae into the sixth year of the ninetcen-year cycle produced dates that were a day out of line with the lunar month in the Dionysiac tables for the remainder of the cycle. In this case, the dislocation made the Victorian 'Greck' Easter of the fifteenth moon fall on what would be the fourteenth moon in the Dionysiac table. Thus the Victorian tables (but only when viewed alongside the Dionysiac tables) seemed to be reverting to the unacceptable paschal limits of the Celtic eighty-four year-cycle; D. O Cróinín, 'New Heresy for Old: Pelagianism in Ireland and the Papal letter of 640', Speculum 60 (1985), 505-16; Wallace-Hadrill, $A$ Historical Commentor', pp. 82-3 and 224-5.

99 D. O Cróinin, 'A Seventh-Century Irish Computus from the Circle of Cummianus', Proc. $R$ Irish Acad., 82c (1982), 405-30; K. Harrison, "A Letter from Rome to the Irish Clergy, $A D$ 640', Peritia 3 (1984), 222-9. 1(x) HE V.19. 


\section{The Frankish Annals of Lindisfarme and Kent}

contention in the 'Celtic-84' Victorius and

40 the papacy in system over $s$ us that Pope :onform to the tten again with northern Irish i's letter, Rome in tables were or Easter 641, [ month which $r$ according to everting to the , be wrong and is aware of the $\therefore$ virtues of the

learned from sy'stem he had Canterbury, to rat, 'the correct arpreted as evior Kent in the ig them on his : era of Christ's

Frankish bishops koning of Time, $\mathrm{pp}$. p. 228.

zen-year cycle proonysiac tables for ian 'Greek' Easter e Dionysiac table. tables) scemed to r year-cycle; D. Ó of $640^{\circ}$, Speculum 60 -5 .

mmianus', Proc. $R$ Irish Clergy, $\lambda D$ incarnation. ${ }^{101}$ However, his dissatisfaction with his teaching in Lindisfarne implies contact there with alternative systems of calculation, perhaps through Ronan, the fiery Irish priest who 'had learned the true rules of the church in Gaul or Italy', but who had failed to convince the Lindisfarne community and succeeded only in rousing Bishop Finan to open hostility. ${ }^{102}$ That Wilfrid had to travel to Rome to find a teacher may simply imply that no one in Northumbria or Canterbury could adequately explain the principles of the Alexandrian calculation to him, rather than the absence of the tables themselves. ${ }^{103}$

I Our evidence, filtered as it is through Bede's Northumbrian lense, does not tell us much about the system used in Kent in the early decades of the seventh century. In the prelude to his account of the Synod of Whitby, Bede says that those who had come de Cantia uel Gallis objected to the Irish custom as being contrary to the teachings of the universal church. ${ }^{104}$ He clearly wanted his readers to understand that the verum et catbolicam pascha which Ronan, the deacon James, Queen Eanflaed and her Kentish priest Romanus had practised in Northumbria before 664 was based on the Cjrlus pascbalis of Dionysius. But up to 664 the dates produced by the Victorian and Dionysiac tables were sufficiently alike that, 'during the whole period of the English conversion, the two tables had been used with reasonable satisfaction side-by-side. ${ }^{105}$

As Jones pointed out long ago, the different practices of worship at the Northumbrian court provided the broad context for the debate at the Synod of Whitby but it was provoked in 664 by the up-coming divergence in the date for Easter in 665, not between the Irish and 'Roman' reckoning, but between the two 'Roman' (Alexandrian) forms of calculation, which was the first time this had happened in living memory. ${ }^{106} \mathrm{Few}$ people would have been able to tell the difference between the two forms of calculation since, aside from the different eras used to anchor the tables in time, they produced the same date for Easter through most of the seventh century. For our purposes, this means that the tables used for calculating Easter in Kent (and in the south of Ireland) up to 664 are as likely to have been those of Victorius as of Dionysius, no matter what Bede would have us believe. As Faith Wallis has pointed out, it is

101 Harrison points out the connection between the earliest incarnation dates in Anglo-Saxon charters and Bishop Wilfrid's activities especially in Mercia, the earliest of which gives a date of 676 (S 51); Harrison, Framework, pp. 61-75; P. Sims-Williams, 'St Wilfrid and Two Charters Dated AD 676 and 680',JEH 39 (1988), 163-83; Charters of St Augustine's, ed. Kelly; pp. lxxxiii-lxxxiv and 139-46, with reference to the earliest Kentish charter to include an incarnation date (9 January 691) in the confirmation by the Mercian king, Wthelred, namely S 10 (Charters of St Alugustime's, ed. Kelly, no. 40). ${ }^{102} H E$ III.25.

103 Wallace-Hadrill, $A$ Historical Commentary, pp. 54 and 235; Wallis, Reckoning of Time, Pp. lxii-lxiii. ${ }^{104} H E$ III.25. ${ }^{105}$ Jones, Bedae Opera De Temporibus, p. 103 and n. 5.

106 Ibid:; idem, 'The Victorian and Dionysiac Paschal Tables in the West', Speculum 9 (1934), 408-21, at 413; Harrison, Framenork, pp. 59-60; Wallis, Reckoning of Time, pp. lxi-lxii. 
Bede who provides the first unequivocal defence of the Dionysiac system in his DTR; Wilfrid's defence at Whitby 'may have secured the victory of the Alexandrian system in Northumbria, but it may not have struck a decisive blow for the Dionysiac version of that system' ${ }^{107}$ It remains possible that our Kentish annals were collected alongside Dionysiac Easter tables, at least from the death of Eadbald in 640, but we have no evidence independent of the late, Frankish copies of our annals to prove the presence of such tables in Kent in the first half of the seventh century. The annals themselves do not provide the unequivocal proof that we might wish of the presence of Dionysiac Easter tables during the early decades of the Roman mission in Kent.

\section{Calendars and epitaphs}

Given the nature of the records, we should also be alert to the possibility that the information they contain was recorded initially in a different format and transferred subsequently to an Easter table. Since the Kentish annals are essentially part of an obit list, one possibility is that they were collected originally around a liturgical calendar. Whereas an Easter table provides space for a notation for each and every' year, the tabular format of a calendar provides space for a notation alongside every day of each month. Calendars also lend themselves to the accumulation of historical notes. Bede tells us of the use of calendars in this context in $H E$ IV.14 where he relates the story of the vision experienced by a young South Saxon boy, dying of plague. In the vision, the boy was told to discover the day on which the saintly King Oswald had died, by checking the calendar, in annale, 'in which the deposition of the dead is noted down' ${ }^{108}$

The best early English example of such a calendar is that linked with Willibrord (Paris, Bibliothèque nationale de France, lat. 10837, fols. $34-41$ and 44, England or Echternach, s. viii ${ }^{1 / 4}$; provenance Echternach), which is a decade or two earlier than the earliest of our sets of Easter table annals. ${ }^{109}$ This calen-

${ }^{107}$ Wallis, Reckoning of Time, p. lxiii.

${ }^{108}$ Megvaert argues that Bede's own calendar which prefixed the DTR lacked hagiographical entries although the anniversary of Oswald's death on 5 August occurs among the York entries of the 'Lorsch Calendar' and in the original portion of Willibrord's Calendar; Meyvaert, 'Discovering the Calendar', pp. 12 and 15; D. A. Bullough, 'York, Bede's Calendar and a pre-Bedan martyrology', $A B 121$ (2003), 329-55, at 334 and 349-50; The Calendar of St IVilibrord from NIS. Paris Lat. 10837: a Facsimile with Transcription, Introduction, and Notes, ed. H. A. Wilson, HBS 55 (London, 1918), 10 and 36.

109 Lowe, CIA V.606a and 606b; Gneuss, Handlist, no. 897; F. Wormald, English Kalendars before A. D. 1100 , HBS 72 (London, 1934). Another early calendar containing early Insular material, Nunich, Haupstaatsarchiv, Raritäten-Selekt 108, Northumbria (or Continent?), s. viii; provenance Tegernsee or Ilmmünster, s. ix, is now lost. On which see, Lowe, CLA IX.1236; Gneuss, Handlist, no. 855.5 and R. Bauerreiss, 'Ein angelsächsisches Kalendarfragment des bayrischen Hauptstaatsarchivs in München', Studien tund Mitteillungen zur Gesclicbte des Benediktiner-Ordens und seiner Zneige 51 (1933), 177-82; Levison, England and the Continent, pp. 273 , at n. 2 , and 278 , at n. 3 . 


\section{The Frankish Annals of Lindisfarne and Kent}

isiac system in victory of the a decisive blow ;sible that our $s$, at least from ent of the late, bles in Kent in 1ot provide the onysiac Easter

possibility that ent format and inals are essenzcted originally sace for a notaivides space for and themselves of calendars in on experienced boy was told to y checking the down'. ${ }^{108}$

at linked with fols. 34-41 and hich is a decade $3 .{ }^{109}$ This calen-

ied hagiographical ; among the York ibrord's Calendar; k, Bede's Calendar 1; The Calendar of St "1, and Notes, cd. H.

glish Kalendars before early Insular mateontinent?), s. viii?; we, CLA IX.1236; endarfragment des zur Gescljicbte des nd the Continent, pp. dar is accompanied by six (Dionysiac) Easter tables, covering the years 684-797, which were those most immediately relevant for the user of the book. ${ }^{110}$ In that manuscript, though, it is the calendar and not the Easter tables which attracted the historical annotations, most famously the marginal note on $39 \mathrm{v}$ written in the year 728 and thought to be in the hand of Willibrord himself. ${ }^{111}$ The calendar also records the anniversary days of a number of secular figures (albeit those with saintly connotations), including the Northumbrian kings Edwin, Oswald and Oswine and, on two occasions in May, the days on which basilicas had been dedicated. ${ }^{112}$ The conjunction of calendar and Easter table within a single codex thus provides the liturgical architecture for recording accurate anniversaries and the year an event had occurred; one provides the day of the month, the other the year. The calendar of Willibrord demonstrates that such a conjunction of Easter table, calendar, and historical notations existed in the early eighth century in the pragmatic context of a missionary's handbook.

Paul Meyvaert has recently demonstrated that an astronomical calendar was devised by Bede to accompany the DTR alongside the Easter tables. ${ }^{113}$ The group of manuscripts that best reflects Bede's calendar includes our manuscript B, from Verona. The calendars in this group also incorporate a list of saints' festivals that derive from a common, early Insular excmplar. Included in this list is a record of the death of Paulinus, bishop of York in Britamia on 10 October. Donald Bullough has argued that another group of DTR calendars contain a different hagiographical compilation including the depositiones of several Northumbrian bishops, kings and saints, as well as church dedications, including the titulus. Agiae Sopbiae on 19 and 30 October and the depositio Aelbrecti arcliepiscopi on 8 November. These entries link that version of Bede's calendar

110 Table 10 (703-21) was copied on the verso of $40 \mathrm{v}$ in the same hand as that of the main calendar; Table 11 (722-40) and Table 12 (741-59) were copied on fol. 41 by a different, but closely contemporary hand. $\Lambda$ borologizm and the text of the mass for the Vigil of $A$ scension was added by a third hand to fol. 42, and that third hand copicd Table 13 (760-78) and Table 14 (779-97) on fol. 43; Table 9 (684-702) was included as a singleton leaf at the end of the volume on $44 \mathrm{r}$ ( $44 \mathrm{v}$ is blank) in a hand similar to Table 10 and the main body of the calendar. Wilson thought that it had been discarded when redundant and used as a fyleaf for the volume, idem. Calendar, p. ix. For a plate of 42v; dated 'post $A$. D. 760', see Lowe, English Uncial, p. 23, pl. XXXVIIIb. 111 Wilson, Calendar, p. 13.

:12 Dedicatio bassilicae sancta mariae in uaedritlaesm, wii kl imiz (36v); dedicatio bassilicae sancti panli in rumleos, iiii kl imnï (36v); Osualdi regis, nonas Agusti (38r); Osnini regis, xiiii kl septembris (38r) Aeduini regis, ïidus Octobris (39r); Wilson, Calendar, pp. 7, 10, 12,30,36-8 and 41. The annual commemoration of the dedication of basilicas should remind us of the dedication stone in Bede's own church at Jarrow, which records the day on which the church of St Paul was dedicated (tiii kl. Jlaias) but uses the regnal (anno XV Ecgfridi regis) and abbatial years (Ceolfridi abbatis ... anno IIII) to locate the event, rather than the era of the Incarnation. On the Jarrow inscription sec, most recently; J. Higgitt, Odda, Orm and Otbers: Patrons and Inscriptions in Later Anglo-Saxom England, Decrhurst Lecture 1999 (Deerhurst, 2004).

113 Meyvaert, 'Discovering the calendar', Pp. 59-63. 


\section{Joanna Story}

to York, and Bullough has suggested that Alcuin may have taken a copy of it to the Frankish court in the $780 \mathrm{~s}$, from where it was widely disseminated. ${ }^{114}$ These two examples show that historical notes about Anglo-Saxon England were transmitted to Francia as marginal additions to both types of prefatory material to the $D T R$, calendars and Easter tables.

It is evident that the dates of the Kentish kings as preserved alongside the

- Easter tables were compiled in a centre that was familiar with the Roman calendar and had a means of retaining such details across the decades. The obvious Kerltish locus in the seventh century is the monastery of SS Peter and Paul at Canterbury (later, St Augustine's). Founded by Augustine, the monastery was built de noto outside the walls of the town under the patronage of King Ethelberht. ${ }^{115}$ It became not just a place of learning and education for the clergy of the new English church but also, given its extra-mural location, the primary burial place of the archbishops of Canterbury and the royal dynasty of Ethelberht. It remained so until 760 when Archbishop Cuthbert chose the new church of St John the Baptist adjacent to the Cathedral as his own burial place; within a few years of that event the monastery had ceased also to be a burial place for Kentish kings as Mercian aggression curtailed the independence of the kingdom. ${ }^{116}$

114 Bullough, 'York, Bede's Calendar', pp. 337-9 and 349; Meyvaert, 'Discovering the Calendar', pp. 15-16. The York entries form part of the so-called 'Lorsch Calendar', the best copy of which (from an exemplar written at Lorsch before AD 814) is now, Berlin, Staatsbibliothek Preussischer Kulturbesitz, Phillipps 1869 (Rose 131), Prüm, s. ix ${ }^{2 / 3}$; provenance St Maximian, Trier. On the Lorsch Calendar, see Bischoff, Katalog, no. 438, p. 92; W. Böhne, 'Das älteste Lorscher Kalendar und seine Vorlagen', Die Reichsabsei Lorscb. Festscbrift zum Gedenken an ibre Stiftung 764, ed. F. Knöpp, 2 vols. (Darmstadt, 1977) II, 171-220; Borst, Reichskalender, pp. 56-8.

$115 H E \mathrm{I} .33$. On the burial role of the monastery, see K. H. Krüger, Königsgrabkirchen der Franken, Angelsachsen und Langobarden bis zur Mitte 8. Jabrbunderts. ein bistorischer Katalog, Münstersche Mittelalter-Schriften 4 (Munich, 1971), 264-87. See also, Charters of St Argustine's, ed. Kelly; pp. xiii-xxv and xxvii (for the suggestion that a lost early gospel book, the Textus S. Adriani, may have included a set of annals with copies of charters from St Augustine's and Minsterin-Thanet).

116 Eadmer (Vita Bregonine) and the Christ Church cartulary of c. 1090 recall the innovation of Archbishop Cuthbert's burial in the church of St John the Baptist, just to the east of the Cathedral; only the fiercely pro-Kentish archbishop Jaenberht (d. 792) was buried thereafter at St Augustine's; N. Brooks, The Early History of the Church of Canterbury: Cbrist Church from 597 to 1066 (Leicester, 1984), pp. 39-40, 51 and 81; Levison, England and the Continent, pp. 181-7. Thomas of Elmham says that $/$ thelberht II (d. 762) was the last king to be buried in St Augustine's. W. St John Hope, 'Recent Discoveries in the Abbey Church of St Austin of Canterbury', Arcbacologia 66 (1915), 377-400, repr. in AC 32 (1917), 1-26; R. U. Potts, 'The Tombs of the Kings and Archbishops in St $\lambda$ ustin's Abbey', $A C 38$ (1928), 97-112; R. Gem, 'The Anglo-Saxon and Norman Churches', English Heritage Book of St Augustine's Abby' Canterbur', ed. R. Gem (London, 1997), pp. 90-122, at 105; $A$. Thacker, 'In Gregory's Shadow? The Pre-Conquest Cult of St Augustine', St Augustine and the Contersion of England, ed. R. Gameson (Stroud, 1999), pp. 374-90 and esp. fig. 14.2. On the end of the Kentish independence, see Charters of St Alugustine's, ed. Kelly; Pp. xv-xvi and 200-3.

92 


\section{The Frankish Annals of Lindisfarne and Kent}

a copy of it ieminated. ${ }^{114}$ con England of prefatory

longside the : Roman calThe obvious $r$ and Paul at onastery was ige of King ation for the location, the al dynasty of hose the new burial place; o be a burial pendence of

$g$ the Calendar', he best copy of Staatsbibliothek ce St Maximian, ıne, 'Das älteste Gedenken an ibre alender, pp. 56-8. chen der Franken, gg, Münstersche stine's, ed. Kelly; Textus S. Adriani, e's and Minster-

te innovation of the east of the ricd thereafter at Cburch from 597 inent, pp. 181-7. be buried in St of St Austin of 3. U. Potts, 'The 17-112; R. Gem, Augustine's Abbey r, 'In Gregory's ssion of England, he Kentish inde-
Bede tells us that Ethelberht had been buried in the church of SS Peter and Paul alongside his Frankish wife, Bertha, in the porticus dedicated to St Martin. ${ }^{117}$ Frankish practice may have provided the example; Clovis, the first Christian king of the Franks, had endowed a church (dedicated first to the Holy Apostles, later St Geneviève) on the highest point of the left (south) bank of the Seine in Paris to serve as his burial place, and by Bertha's day the church built over the shrine of St Denis to the north of the city had become a focal burial place for members of the Merovingian dynasty. ${ }^{118}$ As a royal convert $\mathbb{E}$ thelberht would have been concerned to create a suitably splendid focus for his own burial and those of his successors, one that did justice to his status as well as his new faith, and which would stand in answer to his pagan critics who preferred such things to be done the old way. ${ }^{119}$ Ethelberht's son, Eadbald, continued his dynasty's patronage of the monastery by founding a second church on the site, dedicated to the Virgin, a short distance to the east of the main church. This building became his burial place as well as that of many of the early abbots. ${ }^{120}$ Goscelin's account of the translation of Augustine's relics in 1091 says that Eadbald's tomb, along with those of his seventh-century successors and many of the seventh-and eighth-century abbots, was moved from St Mary's when Abbot Scotland, the first Norman incumbent, commenced work on a new abbey church to replace the two old Anglo-Saxon buildings. ${ }^{121}$

It is very likely that the dates of the burials of the seventh-century kings as found in our annals were remembered in the monastery where they were entombed and their memories venerated as benefactors of the community. These records may have been kept in more than one format, most publicly perhaps as tituli written on or near the tombs themselves. No contemporary royal epitaphs survive from Canterbury, but in this context it is relevant that our annals also record the date of Archbishop Theodore's burial in 690. The

117 HE II.5.

118 Those buried at St Denis in the sixth century included Bertha's stcpgrandmother $\lambda$ regund, wife of Clothar I, and her cousin, Dagobert; S. McKnight Crosby; The Rojal Abbey of Saint Denis from its Beginnings to the Deatls of Suger, 475-1151, ed. P. Z. Blum (New Haven, 1987), pp. 7, 9 and 13-27; I. N. Wood, The Meroringian Kingdoms, 450-751 (London and New York, 1994), pp. 344-5 and 352-5.

"19 S. Kelly; 'The Anglo-Saxon Abbey', St Augustine's Abbey Camterbur', ed. Gem, pp. 33-49, at 35-6.

120 HE II.6. H. M. Taylor and J. Taylor, Anglo-Saxon Arcbitecture, 2 vols. (Cambridge, 1965) I, 134-42 and 145; E. Cambridge, 'The Architecture of the Augustinian Mission', St Aurgustine, pp. 202-27, esp. 209 (where he emphasizes the Ravennan parallels for the mid-seventhcentury churches at St Augustine's).

121 Goscelin, Historia translationis S. Augusfini Episcopi Anglormm Apostoli Il.7-10 and II.28, ed. J. Migne, PL 155 (Paris, 1854), cols. 13-46, at 33-6, and 42-5. See also R. Sharpe, 'The Sctting of St Augustine's Translation, 1091', Canterbury and the Norman Conquest. Churcbes, Saints and Scbolars, 1066-1109, ed. R. Eales and R. Sharpe (London, 1995), pp. 1-13.

93 


\section{Joanna Story}

date given by the annals, .xiii. kal. Octobris, feria .ii. (Monday 19 September), matches Bede's record of the date of Theodore's death in HE V.8. There, Bede quotes the date from the metrical epitaph of 'thirty-four heroic verses' that he says had been written on (or over) Theodore's tomb. His tomb was located within the main body of the church because, by 690 , the north porticus that housed the tombs of Augustine and every archbishop before Theodore was full. ${ }^{122}$

Bede also quotes Augustine's epitaph which, he says, was written on his tomb, scriptum est in tumba. ${ }^{123}$ The last line of the inscription gives the date of Augustine's death, defunctus est septima kalendas Imuias (26 May), which reads like a date from our Kentish annals. No year is given in the epitaph, which says merely that he died during the reign of Ethelberht, and Bede does not supply one here or elsewhere in the $H E{ }^{124}$ We do not know whether Augustine's epitaph was written onto his tomb when his body was moved into the new church by his successor, Lawrence, or if it was supplied at a point later in the seventh century and the date derived from a liturgical calendar (which would have recorded the day but not the year of his death). ${ }^{125}$ But in either case it is interesting that the year of Augustine's death had either been forgotten or was not considered necessary for the perpetuation of his memory at Canterbury.

As a consequence, the year of Augustine's death does not seem to have been available to Bede amid the information that was sent to him from Canterbury by $A$ bbot Albinus. However, the epitaphs of both Augustine and Theodore indicate that in seventh-century Canterbury' such records included calendrical dates that provided the day and the month of their deaths, and that these records were cut or painted on to the tombs or nearby walls. The north porticus where the tombs and the epitaphs of the archbishops were located was the physical locus of the community's collective memoria for the leaders of their church, and mass was celebrated there every Saturday in their honour. ${ }^{126}$ The archiepiscopal epitaphs provide an alternative model for understanding where and why the dates of the burial of the Kentish kings were compiled and preserved, and should encourage us to consider the possibility that the primary context in which these dates came to be written down was as inscriptions associated with the royal tombs.

122 HE II.3. Taylor and Taylor, Anglo-Saxon Arrbitecture I, 134-42 and fig 62.

123 HE II.3; A. Orchard, The Poetic Art of Aldhelm, CSASE 8 (Cambridge 1994), 277-80.

${ }^{124}$ The limits of Augustine's death are marked by Bede's reference to his consecration of Mellitus and Justus in 604 ( $H E$ II.3) and Mellitus's attendance at a Synod in Rome on 27 February 610 (HE II.4); Brooks, Early Histon', p. 11.

125 The depositio domni Atrgustini in Cantia on 26 May is one of the York entries included in the 'Lorsch Calendar'; Mejvaert, 'Discovering the Calendar', p. 15; Borst, Reichskalender, pp. 920-1; Handley, Death, Culture and Socieg, p. 21. 126 HE II.3. 


\section{The Frankish Annals of Lindisfarne and Kent}

19 September), 8. There, Bede verses' that he nb was located ith porticus that Theodore was

written on his ves the date of which reads like ph, which says loes not supply 1er Augustine's $\mathrm{d}$ into the new oint later in the $r$ (which would either case it is orgotten or was it Canterbury. $\mathrm{m}$ to have been om Canterbury and Theodore ded calendrical and that these ie north porticus ocated was the eaders of their honour. ${ }^{126}$ The standing where npiled and preat the primary scriptions asso-

4), $277-80$.

is consecration of od in Rome on 27

ies included in the Reichskalender, pp.
Although no contemporary, early royal Kentish epitaph survives, Goscelin's account of Augustine's translation in the late eleventh century describes in some detail the location, form and decoration of the early archbishops' tombs as thcy appeared in his day, as well as a discussion of some of the seventhcentury royal tombs. ${ }^{127}$ His account was tested by excavation in the early twentieth century when the original location of the archiepiscopal tombs was discovered in the north porticus of the first church on the site. The excavators also uncovered the tombs of some of the Kentish kings in the south transept of the new Norman abbey, where they had been placed after being moved from St Mary's. ${ }^{128}$ Goscelin described how the tombs of four kings, Eadbald (d. 640), Hlothhere (d. 685), Mull (d. 687) ${ }^{129}$ and Wihtred (d. 725) were transferred from St Mary's 'in solemn procession' and placed before the altar of the Virgin in the western tower until they could be translated again into the new church. ${ }^{130}$

The excavation of the south transept of the Norman church uncovered several tombs, two of which contained lead coffin plates identifying the burials as those of Hlothhere and Wihtred. The reference to both kings as rex Anglorum and the form of the script dates both coffin plates to the time of the late-eleventh-century reburial of the kings rather than objects surviving from the original internments in 685 and 725 respectively. ${ }^{131}$ The coffin plates record the obits of the kings:

Hic requies/cit Lotharius / rex : Anglor $m$ : / .VIII. idus. Feb: / obiit ann. DC. // ann. DC / LXXX . V.

Hic requiescit / Wihtredus tex / Anglor $u m$.VIII. kld. / mai obiit anno / DCC.XX.V.

These dates are also provided by Bede and were probably derived from $H E$ IV.26 and V.23 at the time of the eleventh-century reburials rather than local

127 Goscelin, Translatio S. Alugustini I.3, I.9-10, I.16-24, I.28-33, II.7-11, II.27-8; cols. 16-18, 20-8, 34-8, 42-5. $\quad{ }_{128}$ Potts, 'Tombs of the Kings', p. 109.

129 Mull is mentioned in $A S C$ 686-7 as one of the reges dubii rel externi who, Bede says (HE IV.26), attacked Kent after the death of Eadric in August 686 . The disputed succession could provide an explanation for the cessation of the Kentish data as we have them after the death of Eadric. $\quad{ }_{130}$ Goscelin, Translatio S. Augustini II.8-10, cols. 35-6.

131 Potts, 'Tombs of the Kings', pp. 109-12; Gem, 'The Anglo-Saxon and Norman Churches', p. 116 and fig. 54; E. Okasha, Handlist of Anglo-Saxion Non-Runic Inscriptions (Cambridge, 1971), Pp. 60 and 149. The usual style for Kentish kings in the seventh century is rexCantuarionum or rex Cantie (both of which are used in our annals); Charters of St Azgustine's, ed. Kelly; pp. Ixxvii and 232-3; Levison, England and the Continent, p. 187; $A$. Scharer, 'Die Intitulationes der angelsächsischen Könige im 7. und 8. Jahrhundert', Intitulatio III: Lateinische Herrscbertitel und Herrscbertitulaturen rom 7. bis zum 13. Jabrhundert, Mitteilungen des Instituts für Österreichische Geschichtsforschung, Ergänzungsband 29 (1988), 9-74, at 39-48.

95 


\section{Joanna Story}

Canterbury sources (although Wihtred's death is dated a day later on the tablet than by Bede). Nevertheless, Goscelin's account indicates that in late-eleventhcentury Canterbury there was a strong local memory of the places at which individual members of the early Kentish dynasty had been buried. The eleventh-century coffin plates reinforce the suggestion that the community's collective memory of the early Kentish kings may have been sustained by inseriptions which identified the location of their tombs by displaying their names and the calendar date of their deaths or entombments.

The forion in seventh-century Canterbury for recording the dates of royal burials probably came from Rome with the early missionaries. The sixth-and seventh-century entries in the Liber Pontificalis end with a reference to the day of the month on which the pope was buried, often in St Peter's but sometimes in one of the other extra-mural cemeteries. ${ }^{132}$ Rome may also have provided the inspiration for tituli written on or over tombs. Syllogae of metrical epigrams were collected from the mid-seventh century and were brought to AngloSaxon England before the end of the century where they became a hugely influential source for contemporary Anglo-Latin poetry. ${ }^{133}$ Epitaphs from the papal tombs were at the core of these collections and inspired scholars such as Aldhelm, Bede, Cuthbert (archbishop of Canterbury 740-60), and Milred (bishop of Worcester, $733 \times 745-774 \times 775$ ) to compose Latin epigrams in the same manner, along with tituli to celebrate the foundation or dedication of churches. ${ }^{134}$ 'Theodore's epitaph, perhaps composed by Aldhelm, derives directly from this Roman tradition of metrical epitaphs composed for adorn-

132 L. Duchesne, Le Liber Pontificalis: texte introduction et commentaire, 2 vols. (Paris, 1886-92) I, pp. 312-76; R. Davis, The Book of the Pontiffs (Liber Pontificalis): the Ancient Biographies of the First Ninety Roman Bislops to $A D$ 715, 2nd cd. (Liverpool, 2000), pp. 45-89; M. Borgolte, Petrusnacbfolge und Kaiserinnitation: die Grablegen der Päpste, ibre Genese und Traditionsbildung, Veröffentlichungen des Max-Planck-Instituts für Geschichte 95 (Göttingen, 1989), 75-119; J.-C. Picard, 'Étude sur l'emplacement des tombes des papes du $\mathrm{III}^{\mathrm{c}}$ au $\mathrm{X}^{\mathrm{Te}}$ siècle', Meélanges d'Arcbéologie et d'Histoire 81 (1969), 725-82, at 726-7 and 749-58.

133 For the argument that the collection preserved as the Syllogae Laureshamenses Quarta (Vatican City; Biblioteca Apostolica Vaticana, Pal. lat. 833, Lorsch, s. $\mathrm{ix}^{2 / 4}$ ) was compiled by an Anglo-Saxon visitor to Rome in the mid-seventh century; see $\Lambda$. Silvagni, Inscriptiones Clristianae Urbis Romae, nuova serie (Rome, 1922) 1, xxvii; Corporis Lauresbamensis Sylloge Quarta, ed. G. B. De Rossi, Inscriptiontes Cbristianae Urbis Romae septimo saeculo antiquiores, 2 vols. (Rome, 1861-88) I, 95-118. For the suggestion that $A$ ldhelm may have compiled such a sylloge during a journey to Rome, sce Orchard, Poetic Art, pp. 210-12, and M. Lapidge and M. Herren, Aldbelms the Prose II'orks (Cambridge, 1979), p. 164.

${ }^{134}$ On the knowledge and use of these s/llogat in eighth-century England, see Sims-Williams, Religion and Literature, pp. 328-59; idem, 'Nilired of Worcester's Collection of Latin Epigrams and its Continental Counterparts', ASE 10 (1982), 21-38; M. Lapidge, 'Some Remnants of Bede's Lost Liber Epigrammata', EHR 90 (1975), 798-820; Orchard, Poetic Art, pp. 203-12; Lapidge and Herren, Aldhelm, p. 11. 


\section{The Frankish Annals of Lindisfarne and Kent}

$r$ on the tablet late-eleventhlaces at which I buried. The : community's i sustained by isplaying their

dates of royal The sixth- and nce to the day sut sometimes have provided rical epigrams sht to Anglo:ame a hugely aphs from the holars such as ), and Milred pigrams in the dedication of helm, derives sed for adorn-

s, 1886-92) I, pp. raplies of the First 39; M. Borgolte, ' Traditionsbildurn, a, 1989), 75-11); 'c siècle', Mélanges

is Quarta (Vatican compiled by an agni, Inscriptiones ireshamensis Sylloge antiquiores, 2 vols. compiled such a I M. Lapidge and

e Sims-Wiilliams, f Latin Epigrams me Remnants of $A t t$, pp. 203-12; ment of the tomb of the honoured dead. ${ }^{135}$ Commemorative inscriptions of this type would have been familiar to Augustine and his missionaries who accompanied him from Rome in 597, as well as those who reinforced the mission in later years. Ravenna may also have provided a comparable example of such practices. There too the archbishops were buried in a porticus attached to the extra-mural basilica of Sant'Appollinare in Classe, and were identified by epitaphs on the walls above their tombs. ${ }^{136}$ In fifth- and sixth-century Grado, donations, dedications, and burials were remembered in the style of the Eastern Church by floor inscriptions in mosaic. ${ }^{137}$

\section{Lindisfarne}

The Northumbrian annals, as noted already, are of a different character from that of the Kentish entries, and, with the exception of the annal concerning the solar eclipse in 664, no Northumbrian annal in the set is more than two or three words long. In contrast to the Kentish entries that record the ending of reigns, the Northumbrian annals record the year of the accessions of three Northumbrian kings, as well as the year of death (or departure) of three bishops of Lindisfarne. The entry concerning the solar eclipse in 664 is more like the Kentish annals in that it records the day and hour of the event, but it belongs securely to the Northumbrian group, not least because the maximum totality of the eclipse occurred over northern England at the time stated in the annal. ${ }^{338}$ But unlike the Kentish annals, all the information in the Northumbrian entries is found in the HE (but not the $D T R$ ) and may thus have been derived from that text rather than existing independently of it. With the possible exception of the record of the eclipse in 664 , there is no unequivocal evidence that the Northumbrian entries in our annals existed in this form before the composition of the $H E$, despite the desire of Lehmann and others to see

135 T. F. X. Noble, 'Rome in the Seventh Century', Arcbbishop Theodore: Commemorative Studies on bis Life and Infuence, ed. M. Lapidge, CSASE 11 (Cambridge 1995), 68-87; M. Lapidge and J. L. Rosier, Aldhelm: the Poetic IVorks (Cambridge, 1995), pp. 16-17; Orchard, Poetic Art, pp. 277-80.

136 See for example the epitaphs of Bishop John I (477-94) and $A$ rchbishop $A$ gnellus (557-70) from Sant' $\lambda$ gata or the tomb of $A$ rchbishop John II Romanus (d. 595), J.-C. Picard, Le sontvenir des érêgures: sépultures, listes épiscopales et culte des érêques en Italie du Nord des origines an Xé siècle, École Française de Rome 268 (Rome, 1988), 180-9 and figs. 33 and 38; also Thacker, 'In Gregory's Shadow', p. 379. See too, the suggestion by Eric Cambridge that Ravenna provided a closer architectural model than Rome for Canterbury buildings in the mid-seventh century; E. Cambridge, 'The Architecture of the Augustinian Mission', St Algzistine, ed. Gameson, pp. 202-36.

137 Picard, 'Le Souvenir', fig. 52; G. Brusin, Aquileia e Grado, Guida Storico-Artistica (Padua, 1964), pp. 242-58.

138 Whitby was in the path of maximum totality; J. Moreton, 'Doubts about the Calendar: Bede and the Eclipse of 664', Isis 89 (1998), 50-65, esp. fig. 1; Harrison, Framenork, pp. 93-4.

97 
these annals as further proof of the collection of annals in Northumbria before the composition and dissemination of the DTR and $H E \cdot{ }^{139}$ However, there are differences between the chronology of the annals and Bede's work; for example, the date of Finan's death is given as 658 and is common to all our manuscripts, whereas Bede implied in $H E$ III.26 that Finan had had an episcopacy of ten years and thus had died in 661, a decade after Aidan whose death - is given in 651. Also, Osred's accession is dated here to 704, whereas in $H E$ V.18 Bede placed it a year later. ${ }^{140}$ Some but not all of the annals are found in the rhronicle recapitulation in $H E$ V.24, which Levison considered, 'a kind of skeleton and guide for [Bede's] narration ... as remnants of preparatory work', rather than a free-standing source. ${ }^{1+1}$ The overlaps with $H E$ V.24 are the succinct notices for the death of Aidan in 651, and an abbreviated notice of the eclipse and departure of Colman in 664. The Durham group of HE texts (based on Durham, Dean and Chapter Library, B. II. 35, s. xi ${ }^{\text {ex }}$ ) interpolate extra annals to the chapter including a brief addition, Ecefridus regnum suscepit, to the entry for 670 and Osred regnum suscepit to the annal for $705 .{ }^{142}$ Both of these are found in our group of Northumbrian annals, but could have been derived from the main body of the text of the $H E$ rather than from a preexisting set of annals.

The solar eclipse in May 664 is recorded in all of our manuscripts and is the most likely candidate among our Northumbrian annals to have been a note of a contemporary observation, perhaps even one recorded before Bede's day alongside a Dionysiac Easter table. ${ }^{143}$ Bede said that it was an event, 'still remembered in our days'. ${ }^{144}$ The date, however, has been tampered with, for motives intimately associated with the Easter debate; but whether this was Bede's doing, or the work of an earlier Northumbrian computist is not clear. The amended reference to the eclipse as found in our annals is also found in the main body of the $H E$ at III.27, as well as the recapitulation in V.24 and in the world chronicles that Bede embedded in the DTR

139 Lehmann, Fuldaer Studien, pp. 34-7. With reference to the status of the annals in HEV V.24, see Levison, 'Bede as Historian', 136-7, where he argues for Bede's possession of a set of Italian annals as a source for the records of the eclipses in 539 and 540 in $H E$ V.24; idem, England and the Continent, p. 270; C. W. Jones, Saints' Lives and Chronitles in Earb' England (Ithaca, NY, 1947), pp. 31-7; C. R. Hart, 'The Ramsey Computus', EHR 85 (1970), 29-44, at pp. 35-7; Harrison, Frameark, pp. 123-41; Poole, Chronicles and Annals, p. 26.

${ }^{1+0}$ Levison, England and the Continent, pp. 274 and 279, at n. 7, defends the date given in F and $\mathrm{K}$.

${ }^{1+1}$ Levison, 'Bede as Historian', 136.

${ }^{142}$ The 'Durham group' of manuscripts is listed in Bede's Ecclesiastical History, ed. Colgrave and Mynors, pp. xlix-1. The additions made in this group to $H E$ V.24 are given in the critical notes to the chapter, in C. Plummer, I'enerabilis Bedae Opera Historica, 2 vols. (Oxford, 1896) I, 352-60.

${ }^{143}$ W'allis, Reckoning of Time, p. 332; Moreton, 'Doubts about the Calendar', p. 50.

${ }^{144}$ DTR ch. 66, Wallis, Reckoning of Time, p. 230; Jones, Bedae Opera de Temporibus, p. 527. 


\section{The Frankish Annals of Lindisfarne and Kent}

Jorthumbria

${ }^{39}$ However, 3ede's work; on to all our had an episwhose death reas in $H E$ are found in $d$, 'a kind of atory work', are the sucotice of the if $H E$ texts interpolate jnum suscepit, i. ${ }^{142}$ Both of could have from a pre:ripts and is lave been a ded before it it was an ; been tamdebate; but ibrian comund in our as the recain the DTR is in HE V.24, on of a set of IE V.24; idem, Early England (1970), 29-44, ?.6. $\mathrm{en}$ in $\mathrm{F}$ and $\mathrm{K}$. Colgrave and in the critical Oxford, 1896) and in his $D e$ Temporibus. ${ }^{145}$ The manuscripts connected with Fulda (M, F and K) have full details of the event including the hour of totality and the date, but the other copies abbreviate the entry to a single word, eclipsis (further evidence, perhaps, of the two redactions of the text). In five of our manuscripts the next line records the departure of Colman from Northumbria. ${ }^{146}$ These two events are similarly linked in Bede's chronological recapitulation in $H E$ V.24 and the Anglo-Saxon Cbronicle (which is based here on Bede's account in $H E$ III.27 and V.24), but neither of these texts nor our annals makes any refErence to the Synod of Whitby that was the catalyst for Colman's return to Iona. ${ }^{147}$

The date of the solar eclipse of 664 as given in our annals and in all of Bede's texts is two days too late; in these texts we are told it occurred at the tenth hour on the fifth nones of May (3 May; 4.00 p.m.). Only the Irish annals preserve the true date of 1 May. 148 The discrepancy between the observed and recorded date of the eclipse was a particularly awkward problem, both to those seeking to argue for the Alexandrian reckoning at the Synod of Whitby in 664 and for Bede seeking to clinch the argument for the Dionysiac reckoning when writing the DTR sixty years later, since the anomaly cast doubt on the accuracy of the Dionysiac Easter tables. It had been observed at least since Pliny's day that a solar eclipse occurs only when the moon is new; the Easter tables provide the means for calculating the date of the new moon after Easter since the sixth column of the table provides the date of the full moon before Easter and the final column gives the age of the moon on Easter day. ${ }^{149}$ It is a simple matter therefore to count from either of these figures to find the date of the new moon after Easter. In 664, the Dionysiac tables state that the new moon occurred on $3 \mathrm{M}$ ayy, but the eclipse had actually been observed two days earlier. Thus, either the tables were mistaken in the calculations of the age of the Easter moon, or the date of the eclipse in 664 had to be modified to make it agree with the tables rather than the contemporary observation of the phenomenon.

It is natural that our paschal annals record the 'Dionysiac' date for the

145 These are the chronicles edited by Mommsen as the Chronita maiora and the Chronica minora respectively, see above, p. 77, n. 63; also Jones, Beda Venerabilis Opera Didascalica, CCSL 123B, 462-535, at 527, and CCSL 123C, 600-11, at 611, respectively:

${ }^{1+6} \mathbf{M}, \mathbf{P} 1$ and $\mathbf{P} 2$ have Colman abiit, $\mathbf{F}$ and $\mathrm{K}$ have Colman obiit.

$1+7$ Only ASC(E) records the date of the eclipse; The Anglo-Saxon Clironicle M/S E, ed. S. Irvine, The AS Chronicle: a Collaborative Edition, ed. D. Dumville and S. Keynes 7 (Cambridge, 2004), 30.

148 The Amnals of Ulster, cd. S. Mac Airt and G. Mac Nicaill (Dublin, 1983), p. 34; 'Te[ne]brae in kalendis maii in nona hora', i.e. $1 \mathrm{May}, 3.00$ p.m, where the difference in hour represents the time taken for the totality of the eclipse to pass from Ireland to northern England.

149 DTR ch. 27, citing Pliny, Historia naturalis 2.10.56-7; Wallis, Reckoning of Time, pp. 78-80.

99 
eclipse, which concurs with the calculations of the table alongside. In ch. 66 of the DTR the date of the solar eclipse is recorded in exactly the same form as our annals, quasi decima bora diei $V$ nonas Maias (whereas in HE III.27 the direct form of the date is used, die tertio mensis 1 laii, hora circiter decima diet) (pl. I). It is simplest to suppose that the annal for the eclipse as we have it was derived directly from the DTR, which follows the text of the Easter tables in our man- uscripts. But it remains possible that Bede had found the modified Dionysiac dating of the eclipse alongside an Easter table and, realizing that it masked a dingerous computistical anomaly, attempted to explain, with computistical reasoning in chapter 43 of the DTR, 'why the moon sometimes appears older than its computed age. ${ }^{150}$

\section{EIGHTH-CENTURY EXCHANGES}

The Frankish Annals of Lindisfarne and Kent evidently have a complex twoway relationship with the writings of Bede and the transmission of his texts to and within Francia. ${ }^{151}$ They were copied as marginalia to the Cyclus pasclatis, which formed one of the prefatory texts to the De temporum ratione, and the Northumbrian entries are likely to have been derived from the $H E$ rather than from a source common to both. But the Kentish data are independent of Bede's historical works; they seem to fossilize the sort of raw chronological source that was available to him in Jarrow in the early eighth century, and as such are a very rare glimpse of seventh-century Anglo-Saxon history without the Historia ecclesiastica.

The Anglo-Saxon annals preserved in these Frankish manuscripts are not alone in preserving annalistic records that were exchanged between England and Francia in the eighth-century. Another example of news from England being incorporated into a set of Frankish 'minor' annals is provided by the Amales Mosellani (703-97) preserved in a late eleventh-century manuscript ( $\mathrm{St}$ Petersburg, National Library of Russia, lat.O. v. IV. 1, $65 \mathrm{v}-72 \mathrm{v}$, northern France, s. xi/xii) which contains an Anglo-Saxon reference under the year 713, mors Alfidae et Halidulfi regis. ${ }^{152}$ This note is shared with the Carolingian texts known as the Annales Laureshamenses (discussed above), the Annales Alemannici, the Annales Nazarini, and the Amales Guelferbytani, suggesting that the early

150 Wallis, Reckoning of Time, pp. 331-2.

151 R. A. B. Mynors, 'Textual introduction', Bede's Ecclesiastical History, ed. Colgrave and Mynors, pp. xxxix-lxxiv; esp. lxi-Lxx; McKitterick, History and Memory, pp. 92-6 and 209; D. IV: Rollason, Bede and Germany', Jarrow Lecture (2001).

152 Annales Mosellani, ed. I. M. Lappenburg, MGH SS 16 (Hanover, 1859), 491-9; Wattenbach and Levison, Dentschlands Gescbicbtsquellen, pp. 185-8; Ex Insula Lux: Manuscripts and Hagiographical Material Connected with Medietal England, ed. M. Kilpiö and L. Kahlas-Tarkka (Helsinki, 2001), pp. 63-6. The manuscript also contains on fol. 81 a contemporary reference to the compilation of Domesday Book. 


\section{The Frankish Annals of Lindisfarne and Kent}

ch. 66 of ie form as the direct pl. I). It is as derived our manDionysiac masked a istical reaolder than

iplex twois texts to $s$ paschalis, $e$, and the ther than endent of nological $\mathrm{ry}$, and as $y$ without

ts are not I England angland ed by the iscript (St northern year 713 , gian texts Alemannici, the early

nd Mynors, 209; D. WY. inscripts and hlas-Tarkka ry reference parts of all share a common source. ${ }^{153}$ The Anglo-Saxon note refers to the deaths of AElflxd, abbess of Whitby, and Aldwulf, king of the East Angles, who was the son of Abbess Hild's sister, Hereswith. This date fits with Bede's comment in $H E$ III.24 that $\approx$ Elfled lived about sixty years, and that she was barely a year old when her father dedicated her to the church after his victory at the battle of the River Winwaed in 655. The date of Aldwulf's death is not

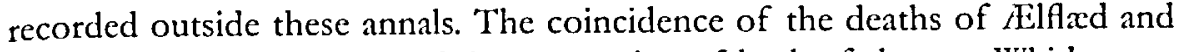
$\Lambda$ diwulf in the same year and the connection of both of them to Whitby suggests that news of their death may have been recorded and disseminated by that monastery. Aldwulf's mother, Hereswith, had retired to the monastery at Chelles in Francia, like several other royal women of the East Anglian dynasty. ${ }^{154}$ Perhaps a connection through which such news might have travelled was maintained with these Frankish monasteries into the early decades of the eighth century. Connections of a similar sort may also account for the obit notices in the Amnales Laureshamenses for the years $704-7$ and $725 / 6-729$ of a number of Irish ecclesiastics including Cellan in 706, abbot of Péronne in Picardie. ${ }^{155}$

There is also evidence for eighth-century Frankish annals being incorporated into Anglo-Saxon annalistic compilations. The best-known example is the eighth-century Latin chronicle interpolated into the twelfth-century composite text commonly known as the Historia regum, which was edited in the late tenth century by Bythtferth of Ramsey and in the early twelfth by Symeon of Durham. ${ }^{156}$ The eighth-century chronicle component of the text, which shows a close interest in the affairs of York, contains several contemporary Frankish annals, which, I have argued elsewhere, were interpolated into that text very early in its history. A group of annals from the 790s section of the Historia regum 'York Annals' shows close textual affiliation with several entries in the

153 Amales Lauresbamenses, Alamannici, Guelferbytani et Nazariani, ed. G. H. Pertz, MGH SS 1 (Hanover, 1826), 19-30, at 22-5; Wattenbach and Levison, Deutscblands Geschicbisquellen, pp. 188-9; W: Lendi, Untersucbuggen zur friihalemamiscben annalistic. Die Murbacher Amalen, Scrinium Friburgense 1 (Frieburg, 1971), 146-7; Collins, 'Charlemagne's Imperial Coronation', pp. 57-8 and n. 28; Halphen, Ėudes critiques, pp. 18-26. ${ }^{154}$ HE IV.23.

155 NIGH SS 1, 22-5; 704, mors Camiani episcopi; 705, dormitio Dommani abbatis, 706, mors Cellani ablatis, 707, dormitio Tigermal; 725, Betto mortum, 726, Martinus et Dubdecris abbati morthi; 728, Hadulfus episcopus mortums, 729, Mlacflatbei morturs.

156 P. Hunter Blair, 'Some Observations on the "Historia Regum" attributed to Symeon of Durham', Celt and Saxon: Studies in the Early British Border, ed. N. K. Chadwick (Cambridge, 1963), pp. 63-118; M. Lapidge, 'Byrhtferth of Ramsey and the Early' Sections of the Historia Regum attributed to Symeon of Durham', ASE 10 (1982), 97-122, repr. in his, Altglo-Latin Literature, 900-1066 (London, 1993), pp. 21-36; C. R. Hart, 'Byrhtferth's Northumbrian Chronicle', EHR 97 (1982), 558-92; J. Story, Carolingian Connections: Anglo-Saxion England and Carolingian Francia, c. 750-c. 870 (Aldershot, 2003), pp. 117-21; D. W. Rollason, Nortbumbria, 500-1100: Creation and Destruttion of a Kingdom (Cambridge, 2003), pp. 15-17.

101 


\section{Joanna Story'}

Annales Laureshamenses; McKitterick has suggested that this may reflect the piecemeal distribution of a libellus or gathering of annalistic entries shortly after they were written. ${ }^{157} \mathrm{~A}$ similar scenario could account for the particular selection of earlier Frankish annals contained in the Historia regum 'York Annals', which from 754 to 775 match closely the subject matter of the abbreviated annals identified by Corradini as representative of the first redaction of the Amales Fuldenses antiquissimi ${ }^{158}$ The Historia regum annals are longer and more descriptive than the Fulda entries, and another annal is included for 772 on Charlemagne's campaign against the Saxons, but the correspondence of subject matter of the two sets of material is striking.

Symeon of Durham was also responsible for compiling and copying another set of annals, which Pertz argued preserved material that was essentially similar to the early Lindisfarne material in the redaction of our annals represented by the St $A$ mand/Salzburg, Verona and Auxerre manuscripts. ${ }^{159}$ These annals, which Pertz and Levison called the Ammales Lindisfarmenses et Dunelmenses, extend from 532-1199 and are found in an early-twelfth-century manuscript from Durham (now Glasgow, University Library, Hunterian 85, Durham, s. xii ${ }^{1 / 3}$, $18 \mathrm{r}-24 \mathrm{v}$ ), where they are written alongside an Easter table. ${ }^{160}$ Pertz considered the annals representative of the common stock of Northumbrian annals on which Symeon and others drew for historical details. ${ }^{161}$ Levison, however, considered the borrowing to have been the other way' around, and that the annals were compiled in the early twelfth century from sources available in Durham; Michael Gullick's identification of the hand of the annals accompanying the second Great Cycle (532-1063) in the Glasgow manuscript shows that this compilation was made and copied by Symeon himself. ${ }^{162}$ The annals in this manuscript deserve greater attention than they can be given here, not least for

157 Story, Carolingian Connections, pp. 95-114; McKitterick, History and Memory, p. 108.

158 Corradini, 'Rhetoric of Crisis', p. 287; idem, 'Zeiträume - Schrifträume', pp. 144-5.

159 Annales Lindisfarnenses et Dunelmenses, ed. G. H. Pertz, MGH SS 19 (Hanover, 1866), 502-8.

${ }^{160}$ W. Levison, "Die "Annales Lindisfarnenses et Dunelmenses" kritisch untersucht und ncu herausgegeben', DAEM 17 (1961), 447-506; J. Young and P. H. Aitken, A Catalogue of the Manuscripts of the Hunterian Musetum in the University of Glasgow (Glasgow; 1908), no. 85, p. 91; R. A. B. Mynors, Durbam Calbedral Manuscripts to the End of the Tuelfth Century (Oxford, 1939), no. 71, p. 55; N. 'Thorpc, The Glory of the Page: Medieval and Illuminated Manuscripts from Glasgon' University Library (London, 1987), no. 9, p. 57.

161 Annales Lindisfarmenses et Dumelmenses, ed. Pertz, pp. 502-3; R. Pauli, 'Karl der Große in Northumbrischen Annalen', Forscbungen zur destscben Gescbicbte 12 (1872), 129-66; Lehmann, Fuldaer Studien, pp. 38-9.

162 Levison, 'Die "Annales", pp. 475-8; $\Lambda$. J. Piper, "The Durham Cantor's Book (Durham, Dean and Chapter Library; MS B.IV.24)', Anglo-Norman Durbam 1093-1193, ed. D. WV. Rollason, M. Harvey and M. Prestwich (Woodbridge, 1994), pp. 79-92; M. Gullick, "The Scribes of the Durham Cantor's Book (Durham, Dean and Chapter Library, MS B.IV.24) and the Durham Martyrology Scribe', ibid. pp. 93-101. 


\section{The Frankish Annals of Lindisfarne and Kent}

reflect the ies shortly : particular ?gum 'York the abbredaction of onger and ed for 772 ndence of ng another ally similar esented by se annals, ses, extend zript from n, s. $\mathrm{xii}^{1 / 3}$, :onsidered annals on 'ever, conthe annals i Durham; anying the ; that this als in this t least for

$-5$.

56), 502-8. and neu her'alogule of the 10. 85, p. 91; :ford, 1939), from Glasgon"

a Große in ; Lehmann,

k (Durham, ed. D. W: ullick, The 3.IV.24) and what they reveal about the methods of a twelfth-century historian and the Anglo-Saxon historical sources available in early Norman Durham. ${ }^{163}$ They show Symeon to have been an avid collector of historical data and a capable scholar who was well able to use and rework historical material for his own ends. It was quite typical of Symeon's intellectual approach and Norman background that he chose to incorporate historical data concerning Carolingian

- Francia as well as entries from an imperial chronology alongside his AngloSaxon material. ${ }^{164}$ The identification of Symeon as the compiler of this twelfth-century set of retrospective paschal annals makes the connection between his text and the 'Frankish annals of Lindisfarne and Kent' that are preserved in our eighth- and ninth-century copies less direct and less secure than Pertz and his followers supposed.

More difficult is the evidence for the set of annals known commonly as the Continuatio Bedae. This text continues the annals in HE V.24 from 732-66, and is found only in a group of late manuscripts from the lower Rhine region, but the late date of the manuscripts and the complexity of the eighth-century Northumbrian chronicle tradition has meant that this text is less well understood than it deserves. ${ }^{165}$ The manuscripts preserve a set of annals closely linked to the eighth-century Historia regum 'York Annals' and to eighth-century annals in the northern recension of the Anglo-Saxon Chronicle. It is generally' assumed that the annals were written into a copy of the $H E$ that was made probably not long after the date of the last annal, ${ }^{166}$ in the extant manuscripts the additions continue the chronicle in the middle of $H E$ V.24 and are followed, as standard, by Bede's autobiography and bibliography which complete the chapter.

The Continuatio contains two Frankish references, recording the death of

163 The annals suggest access to a copy of the northern recension of the Anglo-Saxon Chronicle, the twelfth-century catalogue from Durham records Cronica dro Anglica and Historia Anglorum Anglice, Catalogi Veteres Librorum Ecclesiae Cathedralis Dunelm: Catalogues of the Library of Durbam Catbedral at tarions periods from the Conquest to the Dissolution, cd. B. Botfield, Surtees Soc. 7 (1838), 5; A. J. Piper, 'The Historical Interests of the Monks of Durham', Symeon of Durbam: Historian of Durbam and the North, ed. D. W' Rollason (Stamford, 1998), pp. 301-32, at 312 and 321.

${ }_{16 t}$ Gullick, 'Scribes of the Durham Cantor's Book', pp. 93 and 108. Sce also the short text copied by Symeon now in Durham, Dean and Chapter I.ibrary, B. IV. 22, 3-5r, in which he places Frankish and Anglo-Saxon annals in parallel columns; J. E. Story, 'Symeon as Annalist', Symeon of Durbam, ed. Rollason, pp. 202-13 and pls. 32-41.

165 Continuatio Bedae (CB); Bede's Ecclesiastical History, ed. Colgrave and Mynors, pp. lxviii-lxix and $572-7$.

166 The annal for 757 recording the death of Cynewulf of Wessex wrongly, in error for 786 , seems to be a misreading of the famous annal in the $A S C$ for 755 (recte 757). This may imply: that the $C B$ in the form that we have it today was not written until after the archetype of the $A S C$ was compiled in the later ninth century. Note though that the $C B$ annal does not have the chronological dislocation common to all versions of the $A S C$.

103 
Charles Martel and the accession of Carloman and Pippin in 741, and the martyrdom of Boniface in 754 with fifty-three others and the accession of Hrethgar (Chrodegang) to the bishopric of Metz. 'The reference to Boniface's death is very close to that in the Historia regum 'York Annals', and, like it, should be considered an early import. The reference to the death of Charles Martel is not in the Historia regum, but is probably also an early entry since it shares a curious crror with the Amnales Fuldenses antiquissimi as found in our manuscripts $\mathrm{F}$ and $\mathrm{K}^{167}$ The Annales Fuldenses antiquissimi under the year 742 and the Continuatio Bedae refer to Charles Martel as rex Francorum, which was a rank he never obtained. That this error occurs in our manuscript $F$, in the hand of the primary scribe whom we know to have been working at Fulda in the later eighth century, shows that the error was an early one. This error could be considered a further example of Carolingian historical creativity, clevating Charles Martel to a rank that contemporaries thought he should have had, but it seems more likely that it arose from an eighth-century confusion in which the date of the death of Charles Martel was conflated with the birth of his grandson, Charlemagne.

The Amales Fuldenses antiquissimi have simply Karolus rex Francormm alongside the year 742. It seems that the correct year of Charlemagne's birth was not recorded, or was quickly forgotten. His contemporary epitaph (recorded independently of Einhard's text in our manuscript $F, 31 \mathrm{v}$ ) notes that he died aged 'in his seventies' on 28 January 814 . This would put his birth into the earlier 740 s or later $730 \mathrm{~s}$. By the late 820 s the year of Charlemagne's birth had been narrowed down to 742; a Salzburg scribe adding Frankish annals retrospectively to our manuscript $W$ in the 820 s has natus est Carolus written against the year 742 in the left-hand margin of table 12. Einhard, in his Vita Karoli, concurs with this date saying that Charlemagne had died in the seventy-second year of his life, which gives a date of 742 for his birth. ${ }^{168}$ This date has been accepted by scholars until recently, but Becher has shown that Charlemagne must have been born in 748 (on $2 \mathrm{April}$ ), which is rather later than the estimate given at the time the epitaph was made. ${ }^{169}$ It seems possible that at some point during Charlemagne's lifetime, as illustrated by the date of the annal written into the

167 Corradini, 'Zeiträume - Schrifträume', pp. 141-3, where he suggests that the Fulda annals for 720 (the death of Radbod of Frisia), 735 (the death of Bede), and 742 (Charles) might have been a continuation to the Lindisfarne annals copied into the uncial portion of our manuscript, $\mathbf{M}$.

168 Einhardi Inta Karoli Magni, cd. O. Holder-Egger, MGH SS rer. Germanicarum (Hanover and Leipzig, 1911), pp. 35-6, for the epitaph and Einhard's more precise calculation; Charlenagne's Courtier: the Complete Einhard, ed. and trans. P. E. Dutton, Readings in Med. Civilization and Cultures 2 (Peterborough, Ont., 1998), 35-6.

169 M. Becher, 'Neue Überlieferung zum Geburtsdatum Karls des Grossen', Francia 19 (1992), $37-60$, at $50-4$. 


\section{The Frankish Annals of Lindisfarne and Kent}

ad the marcession of Boniface's :e it, should es Martel is it shares a nanuscripts 12 and the s a rank he and of the in the later uld be coning Charles ut it seems the date of grandson,

'/l alongside th was not orded indee died aged , the earlier h had been retrospecagainst the oli, concurs ond year of in accepted must have ate given at oint during en into the

Fulda annals harles) might ortion of our

(Hanover and ; Charlemagne's vilization and

cia 19 (1992), margins of $F$ at Fulda, the uncertain memory of the year of the king's birth was conflated with a perfectly sound record of the death of his grandfather and namesake, resulting in the ambiguous annal for 742 . Einhard, who was educated at Fulda, seems to have taken this date, perhaps as he found it in the community's Easter tables, and used it to firm up the king's biographical details in his account of his master's death. The Continuatio Bedae preserves an extended version of the Fulda-type annal in its entry for 741, Karolus rex Francormm obiit, adding the names of his successors, et pro eo filiz eizs Karoloman et Pippinum regnum acceperunt. This extended annal seems to have been preserved in Northumbria, because in the 1120s Symeon copied it into the margins of his Easter table annals. But, knowing better, he swapped rex for priuceps. ${ }^{170}$

\section{CONCLUSION}

The annals recorded in these manuscripts repay close attention. As we have seen, not only do they preserve accurate details of the dates of the burials of seventh-century kings of Kent, but they also provide important clues as to the contexts under which such historical notes were first recorded in early Christian England. The Frankish context is crucial; some of the annals are preserved in an English manuscript (M) which we can show was taken to Francia in the mid-eighth century, and we can show that this book (and at least one other that contained the combined Kentish and Northumbrian material) inspired the collection of additional annals relating to particular Frankish monasteries. The textual history and palacography of our manuscripts indicates that the scriptoria of Boniface's monastery at Fulda and that of Alcuin's friend Arn at St Amand and Salzburg were key to the transmission of these texts. That the English annals were recopied in these places and that they remained a relevant part of the collected historical memories of those communities is important testimony to the contribution of Anglo-Saxons to the Carolingian church throughout the eighth century.

The Frankish copies of these annals demonstrates not just the depth of penetration of Bede's writings into the Frankish schools but also of the efforts of many other nameless Anglo-Saxons who travelled to the Continent to fulfil their calling to evangelism and conversion. Theirs was a colonization with deep roots, and one which harked back to the folk memories and origin myths of the 'English peoples' on the Continent. But it is worth pausing in conclusion to consider the possibility that the ninth-century Frankish scribes who copied these historical records, may have done so, not just because of recent memories

170 Lcvison, "Die "Annales", pp. 482 and 496. There was a copy of the Annales Mettenses Priores at Durham in the early twelfth century; it contains one of the fullest histories of the early Carolingian period. It is now, Durham, Dean and Chapter Library, C. IV. 15.

105 
of the Anglo-Saxon missionaries and scholars who had travelled to Francia; they may have copied these notes also because some of the names in them sounded faintly Frankish and familiar. As indeed they were; both Ethelberht and his son Eadbald had married Frankish princesses, and their dynasty used Frankish names. Irminric, Eorcenberht and Hlothhere are all good Frankish names. The recopying of the Kentish annals by Frankish scribes in the ninth century catches echoes of the time when the Kentish royal dynasty; with its Frankish sounding names, had been closely related to Frankish royalty. In short, these 'Prankish Annals of Lindisfarne and Kent' provide a palimpsest of connections between the Franks and the Anglo-Saxons that stretched from before Augustine's mission in the late sixth century through to the age of Charlemagne. ${ }^{171}$

171 My thanks to the British $A$ cademy for grants which enabled me to undertake this research and present the results at the 2003 conference of the International Society of AngloSaxonists, in Arizona, and to the University of Leicester for granting me leave to write it up. I am very grateful too for the constructive comments of Rosamond McKitterick, Elaine Treharne and Alex Burghart on earlier versions of this paper. The 2005 conference of the International Society of $\mathrm{Anglo}$-Saxonists in Munich prompted an exhibition of Anglo-Saxon manuscripts in Bavaria, including manuscript F, Munich, Bajerische Staatsbibliothek, Clm 14641. In addition to the references listed in $\mathrm{nn} .21$ and 22 above, a plate and description of this manuscript can now be found in Angelsäcbsisches Frbe in Mänclen. Anglo-Saxon Heritage in Minicl, ed. H. Sauer, with B. Ebersperger, C. Schreiber and $A$. Schröcker (Frankfurt am Mlain, 2005), pp. 48-9, no. 8.

All of th concerni Anglo-S? the many tions are brackets 
to Francia; ies in them Ethelberht inasty used d Frankish $n$ the ninth ity; with its ty. In short, est of conrom before he age of

this research ty of Angloto write it up. terick, Elaine erence of the Anglo-Saxon bliothek, Clm description of von Heritage in furt am Mlain,

\section{The Frankish Annals of Lindisfarne and Kent}

\section{APPENDIX}

All of the Anglo-Saxon annals given below are found alongside other historical notes concerning Roman, Byzantine or Frankish events. This edition provides simply the Anglo-Saxon entrics. The orthography and capitalization of each entry follows that of the manuscript. Omissions are indicated within square brackets []; common abbreviations are expanded silently; ambiguous abbreviations are indicated within pointed brackets $<>$.

M Münster in Westfalen, Staatsarchiv; MSC 1.243, 1-12r (Northumbria, s. viii ${ }^{2 / 4}$; provenance Fulda, Werden, Corvey)

i. Cyclus Paschalis, fols. 1, 2, 11 and 12

ii. Cyclus Paschalis, fols. 3-10

F Munich, Bayerische Staatsbibliothek, Clm 14641, 32v-47 (Fulda, s. viiiex; provenance Regensburg)

K Kassel, Landesbibliothek, Astron. Fol. 2, 1v-8r (Fulda, s. ix ${ }^{1 / 4}$ )

W Würzburg, Universitätsbibliothek, M. p. th. f. 46, 2r-21r (St Amand, s. ix ${ }^{\text {in }}$; provenance Salzburg)

B Berlin, Deutsche Staatsbibliothek, lat. 128 (Phillipps 1831), 8r-14v (Verona, s. $\mathrm{ix}^{\text {in }}$; provenance Metz)

P1 Paris, Bibliothèque nationale de France, lat. 13013, 8v-18r (Auxerre, c. 830; provenance St. Germain-des-Près)

P2 Paris, Bibliothèque nationale de France, nouv. acq. lat. 1615, 10r-18v (Auxerre, $c$. 830; provenance Fleury) 

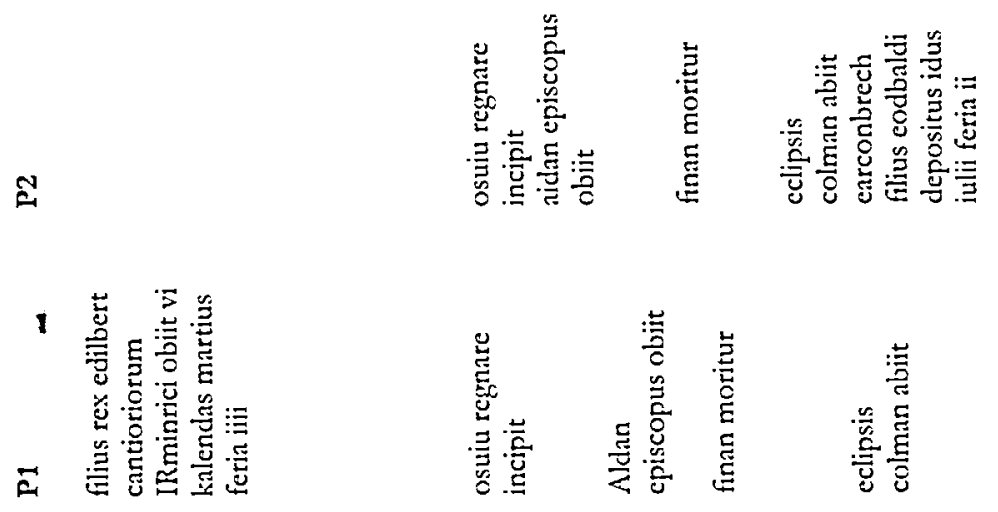

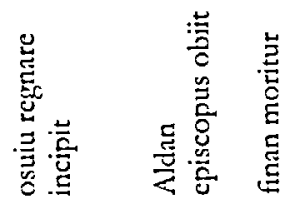

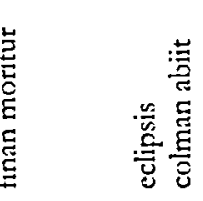

$\oplus$

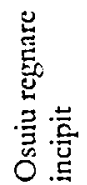

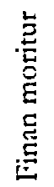

产

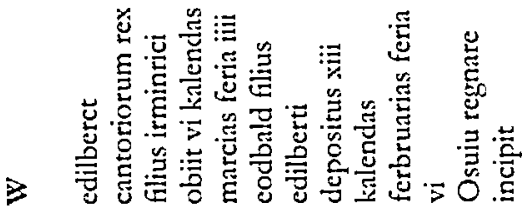

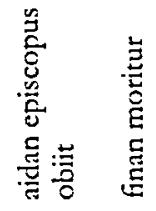

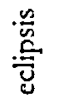

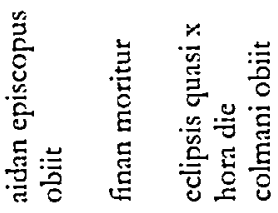

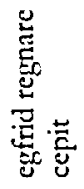

4

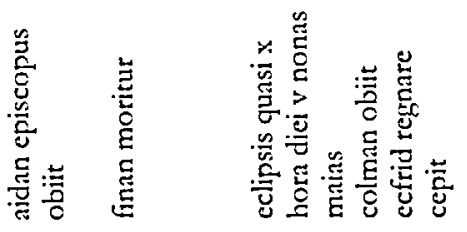

山

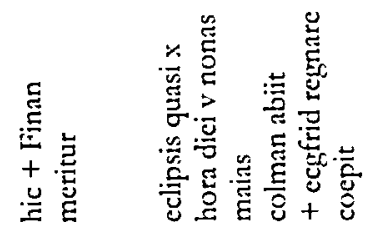

$\Sigma$

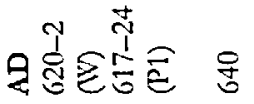
尔
동 동
옹 5 

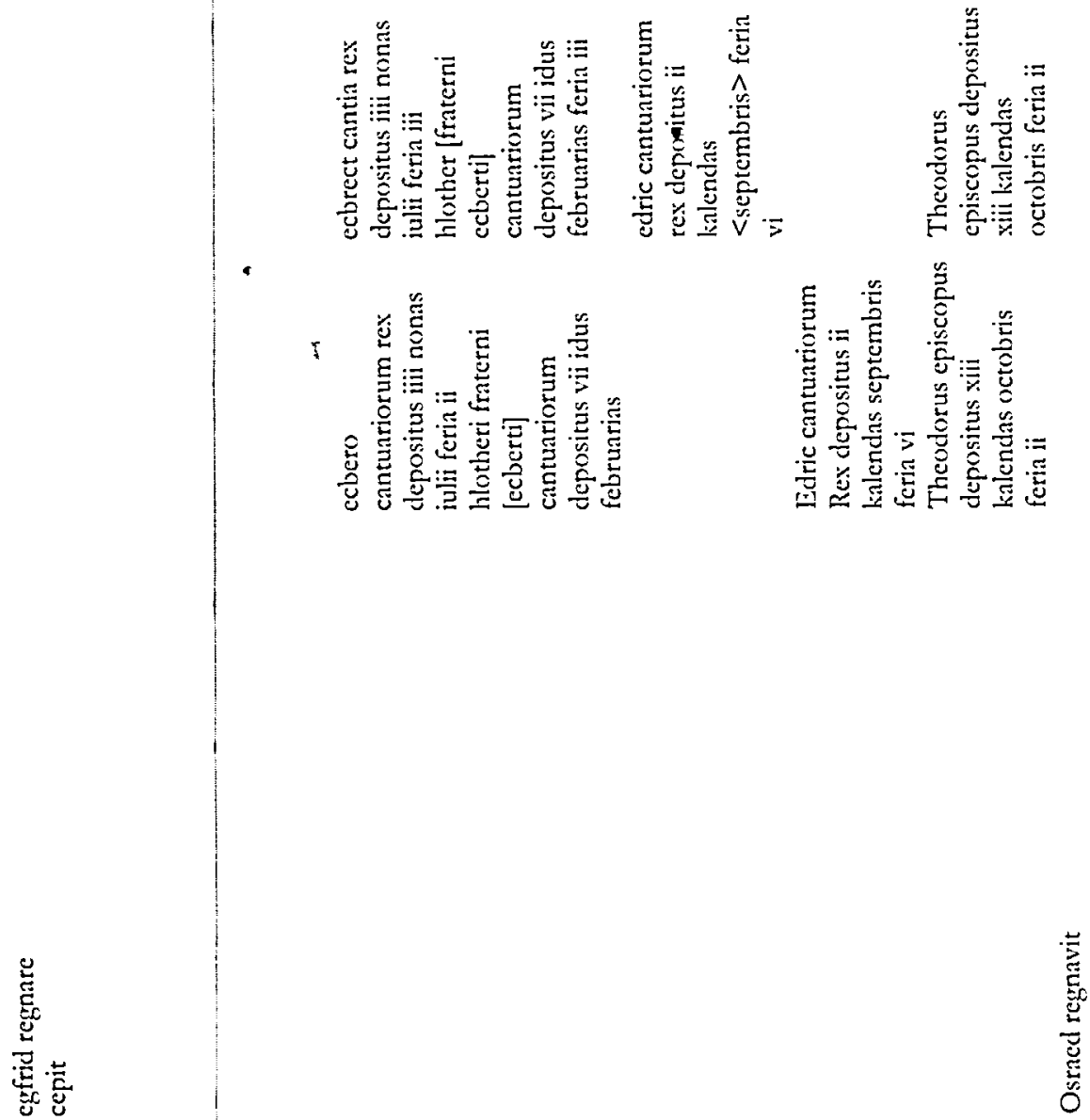

蓉

节

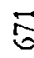

$\stackrel{\infty}{6} \quad \infty$

$\stackrel{\infty}{\circ}$

ळ્వ

옹

$\stackrel{+}{2}$ 